\title{
A Systematic Review on COVID-19 Vaccine Strategies, Their Effectiveness, and Issues
}

\author{
Shahad Saif Khandker ${ }^{1}$, Brian Godman 2,3,4티 ${ }^{1}$ Md. Irfan Jawad ${ }^{5}$, Bushra Ayat Meghla ${ }^{5}$, Taslima Akter Tisha ${ }^{5}$, \\ Mohib Ullah Khondoker ${ }^{1,6}$, Md. Ahsanul Haq ${ }^{1}$, Jaykaran Charan ${ }^{7}$, , Ali Azam Talukder ${ }^{5}$, Nafisa Azmuda ${ }^{5}$, \\ Shahana Sharmin ${ }^{8}$, Mohd. Raeed Jamiruddin ${ }^{1,8} \mathbb{1}$, Mainul Haque ${ }^{9, *}$ and Nihad Adnan $1,5, * \mathbb{C}$
}

1 Gonoshasthaya-RNA Molecular Diagnostic \& Research Center, Dhanmondi, Dhaka 1205, Bangladesh; shahad@rnabiotech.com.bd (S.S.K.); mohib@gonoshasthayakendra.org (M.U.K.); ahsan@rnabiotech.com.bd (M.A.H.); mohd.raeed@bracu.ac.bd (M.R.J.)

2 Strathclyde Institute of Pharmacy and Biomedical Sciences, University of Strathclyde, Glasgow G1 1XQ, UK; Brian.Godman@strath.ac.uk

3 Division of Public Health Pharmacy and Management, School of Pharmacy, Sefako Makgatho Health Sciences University, Pretoria 0204, South Africa

4 Centre of Medical and Bio-Allied Health Sciences Research, Ajman University, Ajman P.O. Box 346, United Arab Emirates

5 Department of Microbiology, Jahangirnagar University, Savar 1342, Bangladesh; rishadirfan97@gmail.com (M.I.J.); meghla.ju@gmail.com (B.A.M.); taslima.tisha.bd@gmail.com (T.A.T.); aat@juniv.edu (A.A.T.); azmuda@juniv.edu (N.A.)

6 Department of Community Medicine, Gonoshasthaya Samaj Vittik Medical College, Savar 1344, Bangladesh

7 Department of Pharmacology, All India Institute of Medical Sciences, Jodhpur 342005, India; charanj@aiimsjodhpur.edu.in

8 Department of Pharmacy, BRAC University, Dhaka 1212, Bangladesh; sharmin@bracu.ac.bd

9 The Unit of Pharmacology, Faculty of Medicine and Defence Health, Universiti Pertahanan Nasional Malaysia (National Defence University of Malaysia), Kem Perdana Sugai Besi, Kuala Lumpur 57000, Malaysia

check for

updates

Citation: Khandker, S.S.; Godman, B.; Jawad, M.I.; Meghla, B.A.; Tisha T.A.; Khondoker, M.U.; Haq, M.A.; Charan, J.; Talukder, A.A.; Azmuda, N.; et al. A Systematic Review on COVID-19 Vaccine Strategies, Their Effectiveness, and Issues. Vaccines 2021, 9, 1387. https://doi.org/ $10.3390 /$ vaccines 9121387

Received: 29 September 2021 Accepted: 18 November 2021 Published: 24 November 2021

Publisher's Note: MDPI stays neutral with regard to jurisdictional claims in published maps and institutional affiliations.

Copyright: (c) 2021 by the authors. Licensee MDPI, Basel, Switzerland. This article is an open access article distributed under the terms and conditions of the Creative Commons Attribution (CC BY) license (https:// creativecommons.org/licenses/by/ $4.0 /)$.
* Correspondence: mainul@upnm.edu.my or runurono@gmail.com (M.H.); nihad@juniv.edu (N.A.); Tel.: +60-1-0926-5543 (M.H.); +880-170-570-9910 (N.A.)

Abstract: COVID-19 vaccines are indispensable, with the number of cases and mortality still rising, and currently no medicines are routinely available for reducing morbidity and mortality, apart from dexamethasone, although others are being trialed and launched. To date, only a limited number of vaccines have been given emergency use authorization by the US Food and Drug Administration and the European Medicines Agency. There is a need to systematically review the existing vaccine candidates and investigate their safety, efficacy, immunogenicity, unwanted events, and limitations. The review was undertaken by searching online databases, i.e., Google Scholar, PubMed, and ScienceDirect, with finally 59 studies selected. Our findings showed several types of vaccine candidates with different strategies against SARS-CoV-2, including inactivated, mRNA-based, recombinant, and nanoparticle-based vaccines, are being developed and launched. We have compared these vaccines in terms of their efficacy, side effects, and seroconversion based on data reported in the literature. We found mRNA vaccines appeared to have better efficacy, and inactivated ones had fewer side effects and similar seroconversion in all types of vaccines. Overall, global variant surveillance and systematic tweaking of vaccines, coupled with the evaluation and administering vaccines with the same or different technology in successive doses along with homologous and heterologous prime-booster strategy, have become essential to impede the pandemic. Their effectiveness appreciably outweighs any concerns with any adverse events.

Keywords: clinical trials; COVID-19 vaccines; systematic review; inactivated vaccines; mRNA vaccines; nanoparticle-based vaccines; recombinant vaccines; prime-booster strategy

\section{Introduction}

The current pandemic of coronavirus disease-19 (COVID-19) caused by Severe Acute Respiratory Syndrome Coronavirus-2 (SARS-CoV-2) is the seventh human coronavirus 
discovered [1]. Previously, in 2002-2003, SARS-CoV and 2015 Middle-East Respiratory Syndrome Coronavirus (MERS-CoV) created outbreaks in southern China and the Arabian Peninsula. Nevertheless, both episodes were centered primarily on their origin country and did not emerge into a worldwide pandemic [2,3].

Coronaviruses are categorized into four genera: Alphacoronavirus, Betacoronavirus, Gammacoronavirus, and Deltacoronavirus [4]. Alphacoronavirus and Betacoronavirus are found in mammals, while Gammacoronavirus and Deltacoronavirus infect birds [5]. HCoV-229E and HCoV-OC43, the two human coronaviruses (HCoVs), were first identified in the 1960s [6,7]. Ten complete genome sequences were available before 2003 [8-10]. After the SARS-CoV epidemic, sixteen more complete genome sequences were added, including two HCoVs (NL63 and HKU1), ten mammalians, and four avian coronaviruses [11-26]. The recent pandemic caused by SARS-CoV2 started in December 2019 in Wuhan, China [27-30]. SARS-CoV-2 belongs to the Betacoronavirus genera, and to the order Nidovirales and Orthocoronavirinae subfamily [31,32]. Although $\mathrm{HCoV}$ OC43, HKU1, 229E, and NL63 mostly create mild respiratory illness, including the common cold in patients, SARS-CoV-2 can be deadly with a moderate to high severity rate similar to SARS-CoV and MERS-CoV [1,33]. The severity of the infection and its transmission is reflected by more than 246 million people having been infected and 49 million lives lost by October 29, 2021 [34].

Usually, respiratory infections occur by transmitting virus-containing droplets or aerosols from infected individuals while talking, breathing, coughing, and sneezing. COVID-19, primarily a respiratory infection, also transmits through airborne aerosols produced from infected persons, including asymptomatic patients, although it is not confirmed if transmission occurs through airborne droplets or aerosol [35-41].

Upon entry into the host by binding the spike protein (S) to human angiotensinconverting enzyme 2 (hACE2), SARS-CoV-2 replicates rapidly in human lung tissue [42]. However, other than the respiratory tract cells, ACE2 receptors are present in the brain, gut, endothelium and vascular smooth muscle cells, and peripheral organs, including the kidneys and liver [43]. In view of this, along with viral pneumonia, SARS-CoV-2 can cause coagulation disorders, cardiovascular impairment, neurological manifestations including systemic and local thrombotic events, ischemic or hemorrhagic stroke, meningoencephalitis, and can cause damage to the kidney and liver [44]. Pro-inflammatory cytokines/chemokines in asymptomatic patients are lower than in symptomatic patients. As a result, the virus rapidly spreads in the pharynx and shedding before symptoms occur $[38,45,46]$. Because of these characteristics, the viral load of SARS-CoV-2 is significantly higher than other respiratory viruses [47,48]. In severe COVID-19 cases, hyperactivation of T-cells, especially CD8+ T-Cells, leads to the release of a higher level of interferon (IFN)- $\gamma$, interleukin (IL)-2, and tumor necrosis factor (TNF)- $\alpha$. However, neutrophilia over lymphopenia finally leads to cytokine storms $[49,50]$.

While many candidates have been proposed to prevent and treat patients with COVID19 , including hydroxychloroquine, lopinavir-ritonavir, molnupiravir, and remdesivir, to date, only dexamethasone has shown a reduction in mortality in hospitalized patients receiving respiratory support; however, there is increasing evidence for medicines such as tocilizumab as well as casirivimab and imdevimab [51-56]. Whilst vaccines are being developed and administered, the recommended approach to reduce morbidity and mortality due to COVID-19 is the instigation of lockdown and social distancing measures [57-60]. However, lockdown measures have unintended consequences. Transport restrictions, closure of clinics, and concerns among patients attending hospital clinics have resulted in increases in non-communicable diseases as well as increased morbidity and mortality among unvaccinated children [61-65]. Lockdown measures also have economic consequences, especially among developing countries [66]. Consequently, there is increased urgency for an effective vaccine to combat COVID-19.

Vaccine development against infectious diseases has a four-century history; however, researchers face challenges developing effective vaccines against emerging infectious diseases $[67,68]$. Several vaccine techniques have already been invented, including live 
attenuated, inactivated, recombinant technologies, adenoviral vector-based, DNA, peptide, and mRNA [69-71]. Recently, nanotechnology has shown new potential in vaccine development [72]. However, nanoparticle-based peptide delivery has many challenges. These include safe delivery vehicles, vaccine adjuvants, antigen stability, targeted delivery, long-time controlled release, and evasion of the immune responses [73-80]. Nevertheless, nanotechnology-based vaccines are easy to design and can be produced on a large scale compared with conventional vaccines. In this ongoing pandemic, nanotechnology and nanomedicine are seen as new therapeutic approaches that could have an appreciable clinical impact [81-88].

To develop vaccines against viruses, knowledge about their genomic and immunogenicity perspectives is essential [28]. Encouragingly, nowadays, information about the genome sequence, including codon and codon pair, junction dinucleotide and individual dinucleotide, RNA structure with several frameshift regions, and transcriptome architecture, has become more accessible for developing vaccines [2,89-91]. Researchers have worked hard to construct effective vaccines against SARS-CoV-2, given the urgency and the lack of effective medicines. Several vaccine candidates, including inactivated, recombinant, mRNA, and nanoparticle-based strategies, have demonstrated their potency [92-95]. Consequently, we sought to review the current vaccine candidates, focusing on their development strategy, adverse events, and effectiveness based on the published findings, as we have been aware there has been considerable misinformation regarding COVID-19 and its prevention and treatment, increasing morbidity, mortality, and costs [65,96-100].

\section{Methodology}

A comprehensive search was undertaken using a systematic approach following the Preferred Reporting Items for Systematic Review and Meta-Analysis (PRISMA) guideline from several online databases (i.e., PubMed, ScienceDirect, and Google Scholar) to determine original research articles on COVID-19 vaccines either in pre-clinical/nonclinical/trial phases or beyond the trial phase [101]. Studies other than full-length research articles, i.e., case reports, review articles, correspondences, and letters, were excluded. Original articles not relevant to the SARS-CoV-2 vaccine were considered ineligible and also excluded. We employed Boolean logical operators ('AND' and 'OR') using 'Advanced' search in PubMed and ScienceDirect selecting 'title' /'abstract' as well as title, abstract, or author-specified 'keywords', respectively, and in Google Scholar selecting 'all entitled with appropriate keywords', i.e., 'COVID-19', 'SARS-CoV-2', 'novel coronavirus', 'n-CoV', 'vaccine', 'clinical', 'clinical study', 'clinical trial', 'randomized control trial', 'RCT', 'efficacy', 'seroconversion', and 'side effects' (Supplementary Table S1). A total of eight authors (S.S.K., M.I.J., B.A.M., T.A.T., M.A.H., M.R.J., M.H., and N.A.) independently screened and assessed the articles to avoid study bias. The search was conducted until 1 September 2021, with no year and language restrictions. Fifty-nine studies (i.e., clinical trials $(n=29)$, and pre-/non-clinical trial or other related original studies $(n=30)$ were included. EndNote X9 software was used to manage the references. The result of the final study selection is based on the inclusion criteria as described in Figure 1. The quality assessment of the clinical trial studies was performed using the standard of the Quality Assessment of Controlled Intervention Studies, NIH, NHLBI [102] (Table 1). 


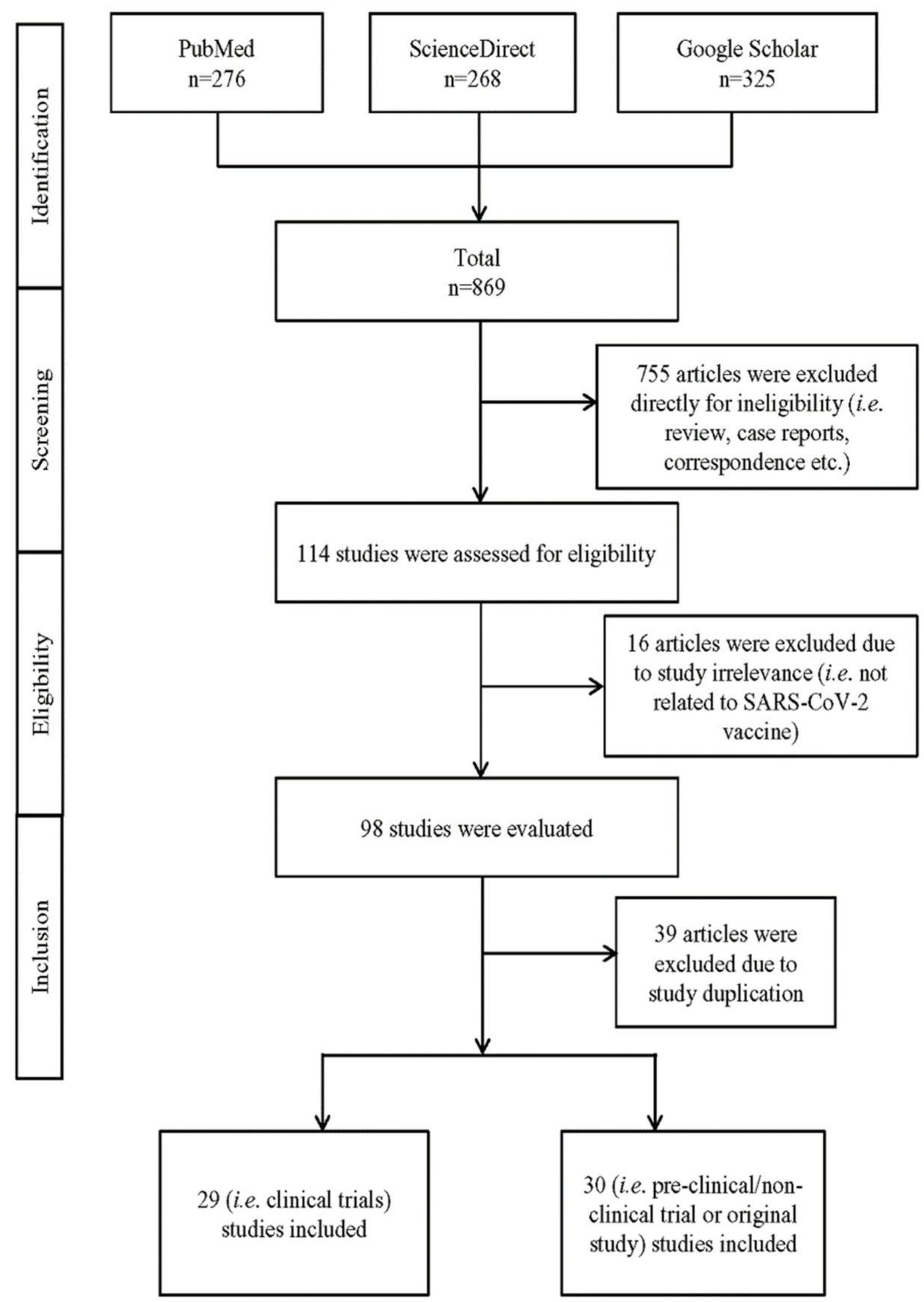

Figure 1. A simplified PRISMA diagram of methodology. Primarily, a total of 869 articles were identified by our search strategy from different online databases (i.e., PubMed, ScienceDirect, and Google Scholar). From this, 755 articles were subsequently excluded due to ineligibility as they were case reports, review articles, correspondence, letters, or articles other than the original full-length article. From the remaining 114 articles, 16 articles were subsequently excluded as they did not match our study criteria (i.e., not related to SARS-CoV-2 vaccines). Ultimately, 59 articles were included for this systematic review after excluding duplicate articles $(n=39)$. Among the final 59 studies, 29 were clinical trials, and 30 were pre-clinical, non-clinical, or other original studies on vaccines. Quality assessments were undertaken for clinical trials. 
Table 1. Quality assessment of the selected studies of clinical trial phase.

\begin{tabular}{|c|c|c|c|c|c|c|c|c|c|c|c|c|c|c|c|}
\hline Study & 1 & 2 & 3 & 4 & 5 & 6 & 7 & 8 & 9 & 10 & 11 & 12 & 13 & 14 & Total Score (\%) \\
\hline Xia S., 2021 & Y & Y & Y & Y & Y & Y & Y & Y & Y & $\mathrm{Y}$ & $\mathrm{Y}$ & NR & Y & $\mathrm{Y}$ & 100 \\
\hline Zhang Y., 2021 & $Y$ & $Y$ & $Y$ & Y & $Y$ & Y & Y & Y & Y & Y & Y & NR & Y & Y & 100 \\
\hline Wu Z., 2021 & Y & Y & Y & Y & Y & Y & Y & Y & $\mathrm{Y}$ & $\mathrm{Y}$ & $\mathrm{Y}$ & $\mathrm{N}$ & Y & Y & 92.8 \\
\hline Tanriover M.D., 2021 & $\mathrm{Y}$ & $Y$ & $\mathrm{Y}$ & $\mathrm{Y}$ & $\mathrm{Y}$ & $\mathrm{Y}$ & $\mathrm{Y}$ & Y & Y & $\mathrm{Y}$ & Y & $\mathrm{N}$ & Y & $\mathrm{Y}$ & 92.8 \\
\hline $\begin{array}{l}\text { Ella R., Reddy, S., Jogdand, H, } \\
2021\end{array}$ & Y & Y & Y & Y & Y & Y & Y & Y & Y & Y & Y & Y & Y & Y & 100 \\
\hline $\begin{array}{l}\text { Ella R., R.; Reddy, S.; } \\
\text { Blackwelder } 2021\end{array}$ & Y & Y & Y & Y & Y & Y & Y & Y & Y & Y & Y & Y & Y & Y & 100 \\
\hline Xia S., 2020 & Y & Y & Y & Y & Y & $\mathrm{Y}$ & Y & Y & Y & $\mathrm{Y}$ & Y & Y & Y & Y & 100 \\
\hline Jackson L.A., 2020 & NA & NA & $\mathrm{N}$ & $\mathrm{N}$ & $\mathrm{N}$ & $Y$ & $\mathrm{Y}$ & $Y$ & $Y$ & $\mathrm{Y}$ & Y & NR & $Y$ & NA & 70 \\
\hline Chu L., 2021 & $\mathrm{Y}$ & $\mathrm{Y}$ & $\mathrm{Y}$ & $\mathrm{Y}$ & $\mathrm{Y}$ & $Y$ & $\mathrm{Y}$ & $\mathrm{Y}$ & $\mathrm{Y}$ & $\mathrm{Y}$ & $\mathrm{Y}$ & NR & $\mathrm{Y}$ & $\mathrm{Y}$ & 100 \\
\hline Baden L.R., 2021 & $\mathrm{Y}$ & $\mathrm{Y}$ & $\mathrm{Y}$ & $\mathrm{Y}$ & $\mathrm{Y}$ & $\mathrm{Y}$ & $\mathrm{Y}$ & $\mathrm{Y}$ & $\mathrm{Y}$ & $\mathrm{Y}$ & $\mathrm{Y}$ & NR & $\mathrm{Y}$ & $\mathrm{Y}$ & 100 \\
\hline Mulligan M.J., 2020 & $\mathrm{Y}$ & $\mathrm{Y}$ & Y & $\mathrm{Y}$ & $\mathrm{Y}$ & $Y$ & $\mathrm{Y}$ & Y & $\mathrm{Y}$ & $\mathrm{Y}$ & $\mathrm{Y}$ & NR & $\mathrm{Y}$ & $\mathrm{Y}$ & 100 \\
\hline Walsh E.E., 2020 & $Y$ & $\mathrm{Y}$ & $Y$ & $\mathrm{Y}$ & $\mathrm{Y}$ & $\mathrm{Y}$ & $\mathrm{Y}$ & $\mathrm{Y}$ & $\mathrm{Y}$ & $\mathrm{Y}$ & $\mathrm{Y}$ & NR & $\mathrm{Y}$ & $\mathrm{Y}$ & 100 \\
\hline Li J., 2021 & $\mathrm{Y}$ & $\mathrm{Y}$ & $\mathrm{Y}$ & $\mathrm{Y}$ & $\mathrm{Y}$ & $\mathrm{Y}$ & $\mathrm{Y}$ & $Y$ & $\mathrm{Y}$ & $Y$ & $\mathrm{Y}$ & $\mathrm{N}$ & $\mathrm{Y}$ & Y & 100 \\
\hline Polack F.P., 2020 & $\mathrm{Y}$ & $\mathrm{Y}$ & $\mathrm{Y}$ & $\mathrm{Y}$ & $\mathrm{Y}$ & Y & $\mathrm{Y}$ & Y & $\mathrm{Y}$ & $\mathrm{Y}$ & $\mathrm{Y}$ & NR & $\mathrm{Y}$ & $\mathrm{Y}$ & 100 \\
\hline Frenck Jr R.W., 2021 & $\mathrm{Y}$ & $\mathrm{Y}$ & $\mathrm{Y}$ & $\mathrm{Y}$ & $\mathrm{Y}$ & $\mathrm{Y}$ & $\mathrm{Y}$ & $\mathrm{Y}$ & $\mathrm{Y}$ & $\mathrm{Y}$ & $\mathrm{Y}$ & NR & $\mathrm{Y}$ & $\mathrm{Y}$ & 100 \\
\hline Chang-Monteagudo A., 2021 & NA & NA & $\mathrm{N}$ & $\mathrm{N}$ & $\mathrm{N}$ & $\mathrm{Y}$ & $\mathrm{Y}$ & $\mathrm{Y}$ & $\mathrm{Y}$ & $\mathrm{Y}$ & $\mathrm{Y}$ & NR & $\mathrm{Y}$ & NA & 70 \\
\hline Zhu F.C., Li, Y.H, 2020 & $\mathrm{~N}$ & NA & $\mathrm{N}$ & $\mathrm{N}$ & $\mathrm{N}$ & $\mathrm{Y}$ & $\mathrm{Y}$ & $\mathrm{Y}$ & $\mathrm{Y}$ & $\mathrm{Y}$ & $\mathrm{Y}$ & NR & $\mathrm{Y}$ & NA & 63.6 \\
\hline Zhu F.C., Guan, X.H, 2020 & $\mathrm{Y}$ & $\mathrm{Y}$ & $\mathrm{Y}$ & $\mathrm{Y}$ & $\mathrm{Y}$ & $\mathrm{Y}$ & $\mathrm{Y}$ & $\mathrm{Y}$ & $\mathrm{Y}$ & $\mathrm{Y}$ & $\mathrm{Y}$ & NR & $\mathrm{Y}$ & $\mathrm{Y}$ & 100 \\
\hline Wu S., 2021 & $\mathrm{Y}$ & $\mathrm{Y}$ & $\mathrm{N}$ & $\mathrm{N}$ & $\mathrm{N}$ & $\mathrm{Y}$ & $\mathrm{Y}$ & $\mathrm{Y}$ & $\mathrm{Y}$ & $\mathrm{Y}$ & $\mathrm{Y}$ & $\mathrm{N}$ & $\mathrm{Y}$ & $\mathrm{Y}$ & 71.4 \\
\hline Folegatti P.M., 2020 & $\mathrm{Y}$ & $\mathrm{Y}$ & $\mathrm{Y}$ & $\mathrm{Y}$ & $\mathrm{Y}$ & $Y$ & $\mathrm{Y}$ & $\mathrm{Y}$ & $\mathrm{Y}$ & $\mathrm{Y}$ & $\mathrm{Y}$ & NR & NR & $\mathrm{Y}$ & 100 \\
\hline Ramasamy M.N., 2020 & $\mathrm{Y}$ & $\mathrm{Y}$ & $\mathrm{Y}$ & $\mathrm{Y}$ & $\mathrm{Y}$ & $\mathrm{Y}$ & $\mathrm{Y}$ & $\mathrm{Y}$ & $\mathrm{Y}$ & $Y$ & $\mathrm{Y}$ & NR & NR & $\mathrm{Y}$ & 100 \\
\hline Denis Y. Logunov, 2020 & $\mathrm{~N}$ & NR & NR & $\mathrm{N}$ & $\mathrm{N}$ & Y & $\mathrm{Y}$ & $\mathrm{Y}$ & $\mathrm{Y}$ & $\mathrm{Y}$ & $\mathrm{Y}$ & NR & NR & $\mathrm{Y}$ & 70 \\
\hline Denis Y. Logunov, 2021 & $\mathrm{Y}$ & $\mathrm{Y}$ & $\mathrm{Y}$ & $\mathrm{Y}$ & $\mathrm{Y}$ & $\mathrm{Y}$ & $\mathrm{NR}$ & NR & $\mathrm{Y}$ & $\mathrm{Y}$ & $\mathrm{Y}$ & $\mathrm{Y}$ & NR & $\mathrm{Y}$ & 100 \\
\hline J. Sadoff, 2021 & $\mathrm{Y}$ & $\mathrm{Y}$ & Y & $\mathrm{Y}$ & $\mathrm{Y}$ & Y & NR & NR & $\mathrm{Y}$ & $\mathrm{Y}$ & $\mathrm{Y}$ & NR & NR & $\mathrm{Y}$ & 100 \\
\hline J. Sadoff, 2021 & Y & $\mathrm{Y}$ & $\mathrm{Y}$ & $\mathrm{Y}$ & $\mathrm{Y}$ & $Y$ & $\mathrm{Y}$ & $\mathrm{Y}$ & $Y$ & $Y$ & $\mathrm{Y}$ & $\mathrm{Y}$ & NR & $\mathrm{Y}$ & 100 \\
\hline C. Keech, 2020 & $\mathrm{Y}$ & $\mathrm{Y}$ & Y & NR & $\mathrm{Y}$ & Y & $\mathrm{Y}$ & Y & Y & $Y$ & Y & $\mathrm{Y}$ & $\mathrm{Y}$ & $\mathrm{Y}$ & 100 \\
\hline P.T. Heath, 2021 & $Y$ & $\mathrm{Y}$ & $Y$ & NR & $\mathrm{Y}$ & $Y$ & $\mathrm{Y}$ & $Y$ & $Y$ & $\mathrm{Y}$ & $\mathrm{Y}$ & $\mathrm{Y}$ & $\mathrm{Y}$ & $\mathrm{Y}$ & 100 \\
\hline Ewer K.J.,2021 & $Y$ & $\mathrm{Y}$ & $Y$ & NR & NR & $Y$ & $\mathrm{Y}$ & $\mathrm{Y}$ & $\mathrm{Y}$ & $\mathrm{Y}$ & $\mathrm{Y}$ & NR & NR & $\mathrm{Y}$ & 100 \\
\hline Barrett J.R.,2021 & Y & Y & $\mathrm{Y}$ & $\mathrm{Y}$ & $\mathrm{Y}$ & $\mathrm{Y}$ & $\mathrm{Y}$ & $\mathrm{Y}$ & $\mathrm{Y}$ & $\mathrm{Y}$ & $\mathrm{Y}$ & NR & NR & $\mathrm{Y}$ & 100 \\
\hline
\end{tabular}

Here, $\mathrm{Y}=$ Yes, $\mathrm{N}=\mathrm{No}, \mathrm{NR}=$ Not reported, NA = Not applicable; 1 . Was the study described as randomized, a randomized trial, a randomized clinical trial, or an RCT? 2. Was the method of randomization adequate (i.e., use of randomly generated assignment)? 3. Was the treatment allocation concealed (so that assignments could not be predicted)? 4. Were study participants and providers blinded to treatment group assignment? 5. Were the people assessing the outcomes blinded to the participants' group assignments? 6 . Were the groups similar at baseline on essential characteristics that could affect outcomes (e.g., demographics, risk factors, co-morbid conditions)? 7. Was the overall drop-out rate from the study at the endpoint $20 \%$ or lower than the number allocated to treatment? 8 . Was the differential drop-out rate (between treatment groups) at endpoint 15 percentage points or lower? 9. Was there high adherence to the intervention protocols for each treatment group? 10. Were other interventions avoided or similar in the groups (e.g., identical background treatments)? 11. Were outcomes assessed using valid and reliable measures implemented consistently across all study participants? 12. Did the authors report that the sample size was sufficiently large to detect a difference in the main outcome between groups with at least $80 \%$ power? 13 Were outcomes reported or subgroups analyzed prespecified (i.e., identified before analyses were conducted)? 14. Were all randomized participants analyzed in the group to which they were originally assigned, i.e., did they use an intention-to-treat analysis?

\section{Current Vaccine Candidates}

Recent advances in bioprocess technology, genomics, structural biology, and immunopathology have significantly contributed to the speed of COVID-19 vaccine development. Researchers have used accumulative knowledge from previous vaccine candidates, and within twenty-two months of the emergence of COVID-19, developed 155 preclinical vaccine candidates with 23 emergency use authorized ones. In this review, we will discuss four different types of COVID-19 vaccine strategies (Figure 2), including

(1) inactivated,

(2) mRNA,

(3) viral vector, and 


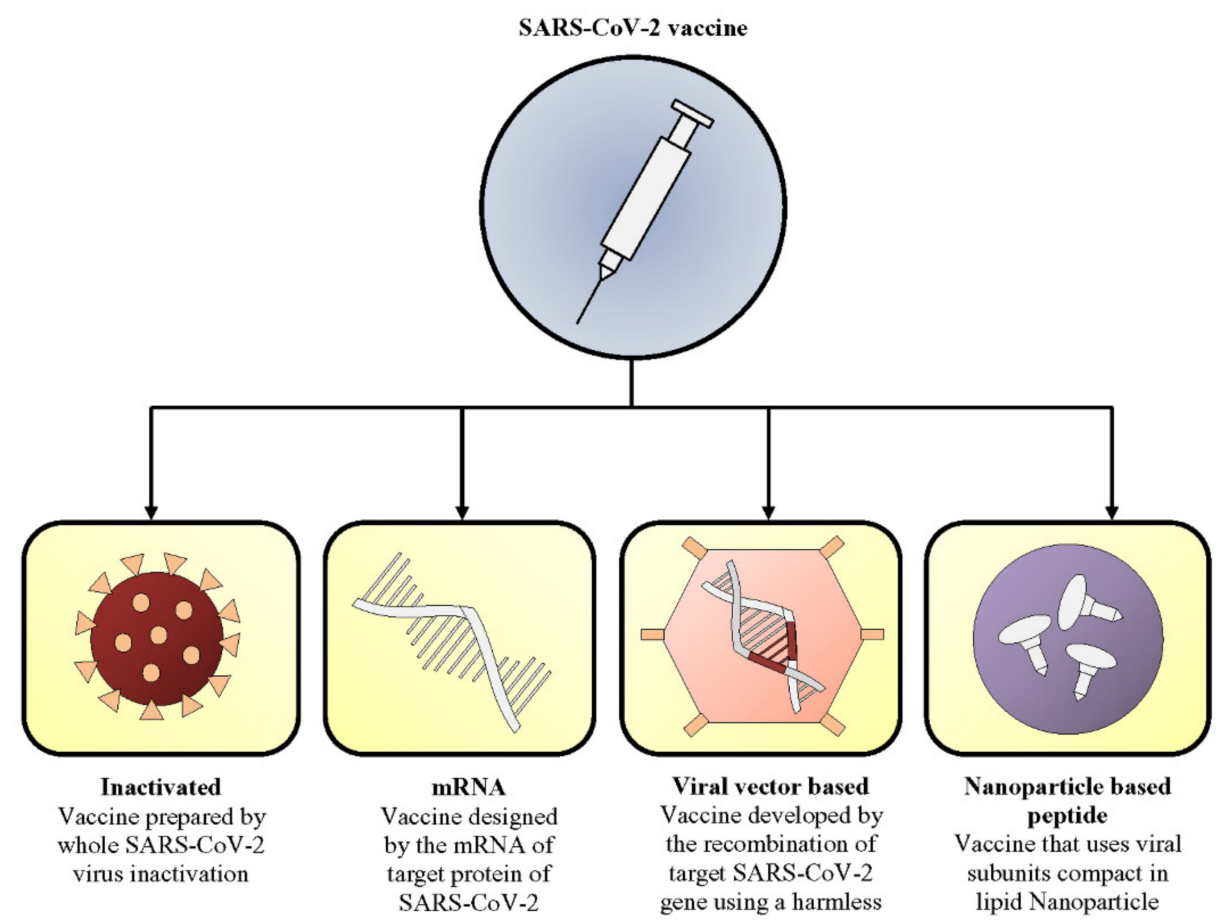

Figure 2. Types of COVID-19 vaccine developed based on different technologies.

\subsection{Inactivated Vaccine}

Inactivated vaccines are formulated by inactivating virulent particles of viruses by treating the virus particle with chemicals, including formaldehyde, $\beta$-propiolactone, ethylenimine, phenol, ascorbic acid, $\beta$-aminophenylketone, and diethylpyrocarbonate [103]. Among these inactivating chemicals, formaldehyde is currently not used to reduce the risk of incomplete inactivation [104]. Since the virus particles are inactivated, they cannot multiply after entering the human body. Consequently, they are safe for administration but need to be introduced in large amounts compared to live attenuated vaccine [104]. Besides, the particles stay in place for the immune system to recognize and process. They induce inefficient cellular and humoral immune responses, showing minimal or no long-term memory response. However, many killed virus particles and adjuvants such as aluminum hydroxide are added to the vaccine formulation to improve their efficacy [105].

The previous SARS-CoV outbreak happened from the autumn of 2002 to the spring of 2003; 8098 became infected, and 774 died in 26 countries [106,107]. There was no approved antiviral medicine against SARS-CoV to prevent such an outbreak. Two types of vaccines, the whole killed virus (WKV) vaccine and the Ad-vectored vaccine, were tested for their potency in producing neutralizing antibodies in the ferret [108]. The study results showed that the WKV vaccine induced a 15-fold higher production of neutralizing antibodies than the other vaccine [108-111]. Another inactivated SARS-CoV vaccine study was conducted in BALB/c mice. The vaccine was prepared by culturing SARS-CoV in the Vero cell line followed by inactivation with $\beta$-propiolactone and purification by Sepharose 4FF column chromatography. The result demonstrated that a higher vaccine dosage was required to produce a higher neutralizing antibody titer [112].

Further observation declared that the vaccine works better if formulated with aluminum hydroxide as an adjuvant [112]. During the outbreak of another type of coronavirus in 2012, designated as MERS-CoV, more than 2468 cases occurred in 27 countries, with over 815 deaths occurring globally [113-117]. Two types of vaccine formulations were studied in mice, a spike protein and a whole inactivated MERS-CoV vaccine, where the latter presented better immune response in mice [118,119]. 
BBIBP-CorV is a whole virion inactivated vaccine manufactured by Sinopharm (Beijing, China) and formulated by inactivating the novel coronavirus strain HB02, isolated from a patient admitted to the hospital. The reason behind the selection was its replication efficiency in Vero cells $[120,121]$. CoronaVac, another inactivated SARS-CoV-2 whole virion vaccine manufactured by Sinovac Life Sciences Co., was assembled by propagating the virus in Vero cells, followed by the inactivation using $\beta$-propiolactone. Aluminum hydroxide was coupled to the vaccine formulation as an adjuvant [122]. During the phase $1 / 2$ trial (human model; age 18-59 years), the production process of the vaccine was slightly different. The cell factory process was used to generate 50L Vero cell culture for the preclinical and Phase 1 trials, respectively, while for the Phase 2 trial, a bioreactor process was used for vaccine production [122].

Interestingly, the bioreactor production process was more appropriate, as the control of the environment was easier and accurate during vaccine production. Moreover, it was suitable for bulk production and ensured the biosafety requirements. The bioreactor batch of the vaccine contained a higher spike antigen than the vaccine used in the phase 1 trial, which was unexpected. Fortunately, it did not change the vaccine's safety profile. Instead, it increased the immunogenicity of the vaccine candidate [122]. A separate study was conducted to evaluate the vaccine's immunogenicity and safety in people aged 60 and older with CoronaVac vaccine. This study showed that the vaccine was suitable for older people as well [123]. A Phase 3 trial of CoronaVac was conducted in Turkey. It was a double-blind, randomized, placebo-controlled trial with 10218 volunteers aged 18-59 years. Among the participants, nine cases of COVID-19 were seen in the vaccine group, whereas thirty-two cases were reported in the placebo group during a follow-up period of 43 days. The overall efficacy of the vaccine was $83.5 \%$ after the second dose. A total of $18.9 \%$ of the population in the vaccine group and $16.9 \%$ in the placebo group experienced minor adverse events; injection site pain was the most frequent adverse event [124].

BBV152 (Covaxin), another whole virion inactivated vaccine developed by Bharat Biotech (India), was produced by inactivating the virus and then formulating it with a toll-like receptor $7 / 8$ agonist molecule, which was absorbed to alum (Algel-IMDG) [92]. The formulation of this vaccine was decided after its preclinical trial in BALB/c mice, New Zealand white rabbits, and the Syrian hamster model. Three types of formulations, BBV152A (0.3 $\mu \mathrm{g} \mathrm{Ag}+$ Algel-IMDG), BBV152B (0.6 $\mu \mathrm{g} \mathrm{Ag}+$ Algel-IMDG), and BBV152C $(0.6 \mu \mathrm{g} \mathrm{Ag}+$ Algel), were assessed. The BBV152B formulation showed a 10-fold better immune response in mice, whereas BBV152A showed better results in the Syrian hamster. Confirmation of the safety and reactogenicity of the vaccine formulation enabled it to receive approval for trials in humans $[125,126]$. The other inactivated vaccine developed by Sinopharm (Beijing, China) (ChiCTP2000031809) was also made by isolating a SARS-CoV-2 strain WIV04 from a patient. The virus was cultivated in Vero cells, and the supernatant of the infected cell was treated with $\beta$-propiolactone to inactivate the virus. Alum was used as an adjuvant to the vaccine formulation [127].

After administering the inactivated vaccine formulations, mild side-effects such as pain in the injection site, fever, fatigue, headache, nausea, and vomiting were observed. Nevertheless, no profound negative result was reported, confirming that they were safe and immunogenic $[92,120,122,123,127]$. However, it is to be noted that, compared to the other vaccines, the adverse events of the BBV152 vaccine, developed by Bharat Biotech, were noticeably lower [92].

Human trials with the above-discussed inactivated vaccine formulations induced considerable immune responses. Seroconversion was reported in all participants of these vaccine studies. Overall, the efficacies of these inactivated vaccines, such as BBIBP-CorV $(82.50 \%)$, BBV152 $(81 \%)$, and CoronaVac $(83.5 \%)$, were found to be almost similar to each other (Figure 3). The neutralizing antibody $(\mathrm{Nab})$ titer was seen to be increasing with the increased dosage of the vaccine (Figure 4). However, the increased dosage caused unfavorable events in the trial population in each trial, as mentioned above, other than the CoronaVac trial (Figure 5) $[92,120,127]$. For CoronaVac, Nab titer and minor unusual 
reactions to the vaccine were the same in the higher $(6 \mu \mathrm{g})$ and lower $(3 \mu \mathrm{g})$ groups. Thus, $3 \mu \mathrm{g}$ dose of the vaccine was selected for the Phase 3 trial [122]. The cellular and humoral response and T cell memory response were generated by BBV152, although the B cell memory response is yet to be assessed [92].

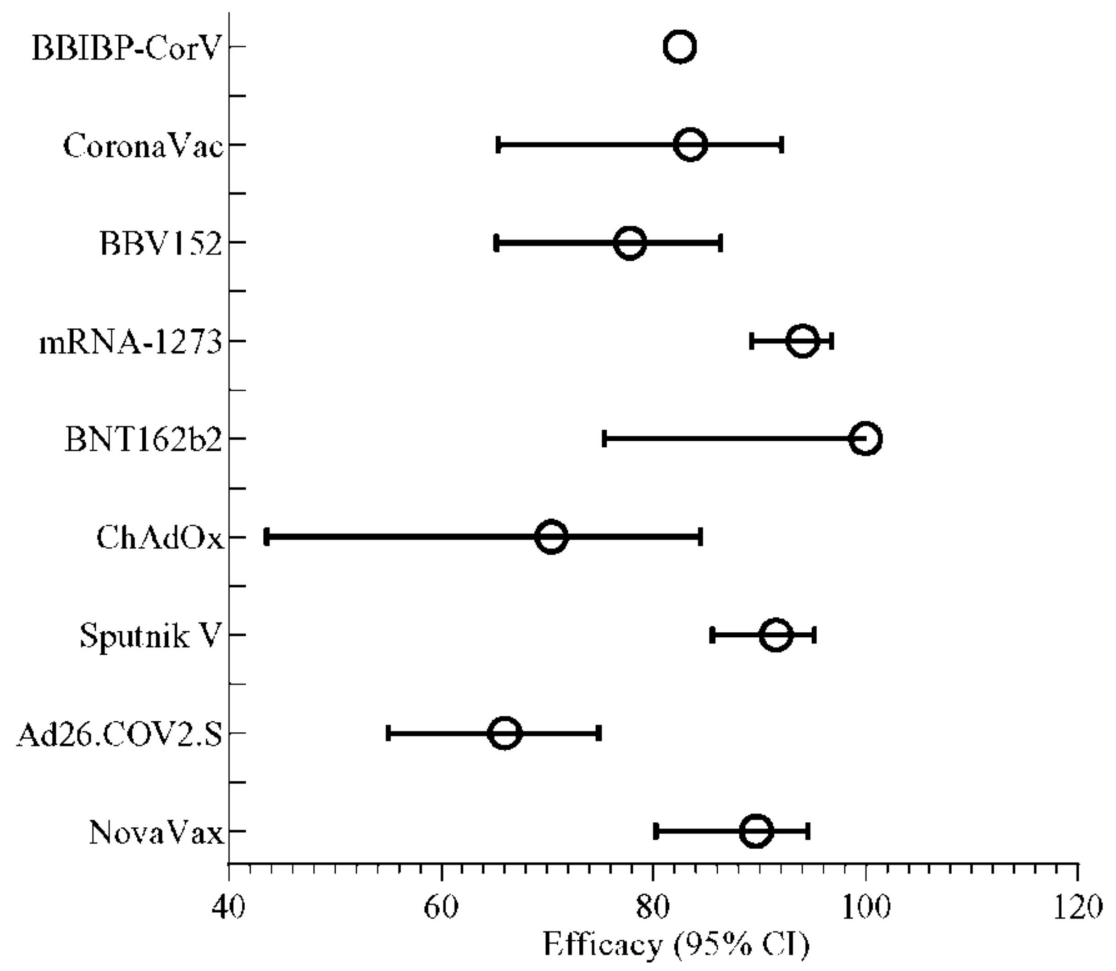

Figure 3. Efficacy of different SARS-CoV-2 vaccine candidates. Here, the small circles imply the reported efficacy after vaccination. All the data were extracted from the included articles, which were selected for this systematic review only. As all the vaccines did not have the same response levels, the $95 \%$ CIs were not evenly distributed. For BBIBP-CorV, we were not able to find the upper and lower limits of $95 \% \mathrm{CI}$; thus, it was not reported in the figure. 


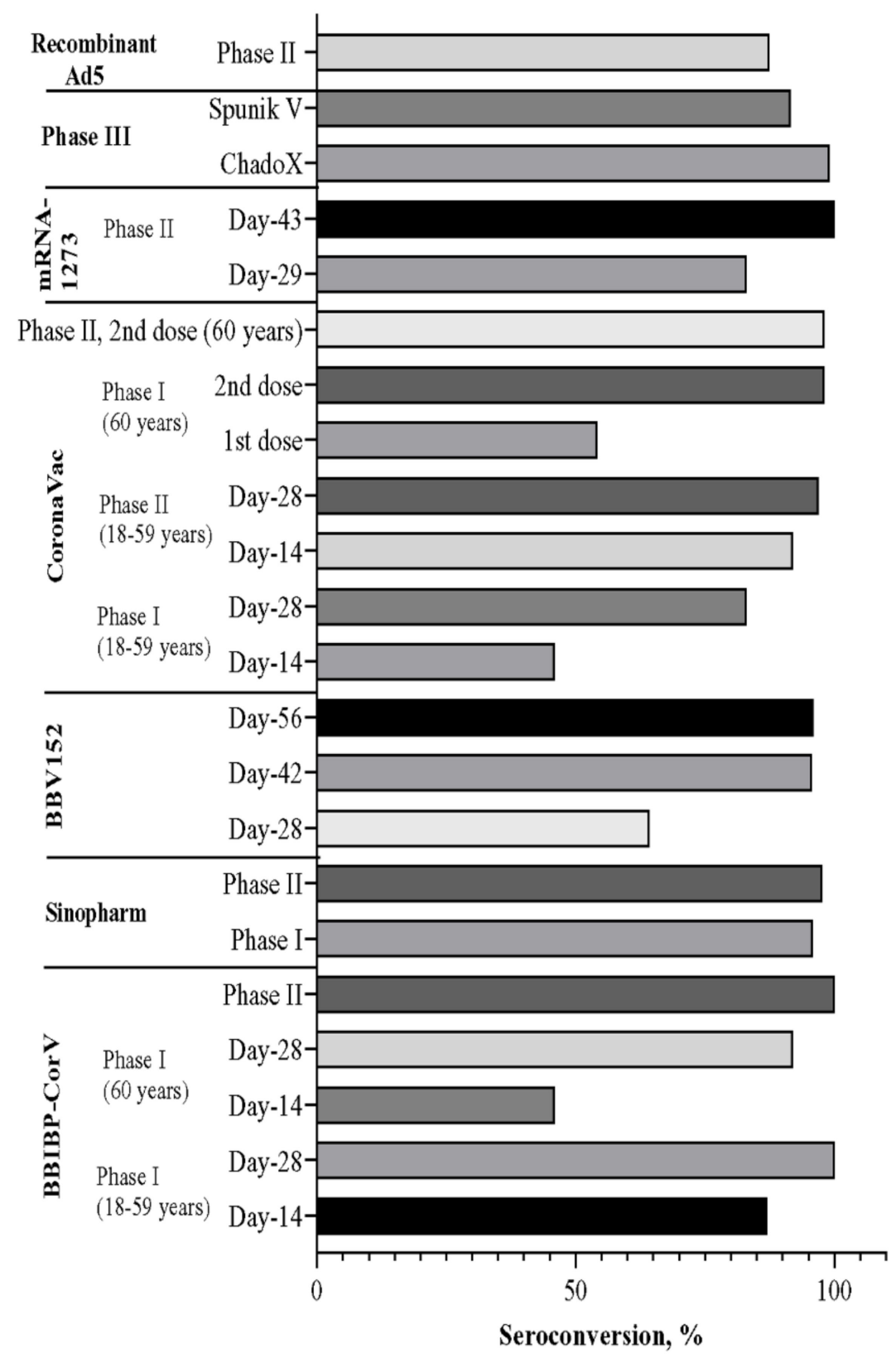

Figure 4. IgG seroconversion of several SARS-CoV-2 vaccines by trial Phase (i.e., Phase I/II/III), dose number (i.e., 1st or 2nd dose), or days after vaccination (i.e., day 14/28/29/42/56). Data were extracted from the included articles which were selected for this systematic review only. 


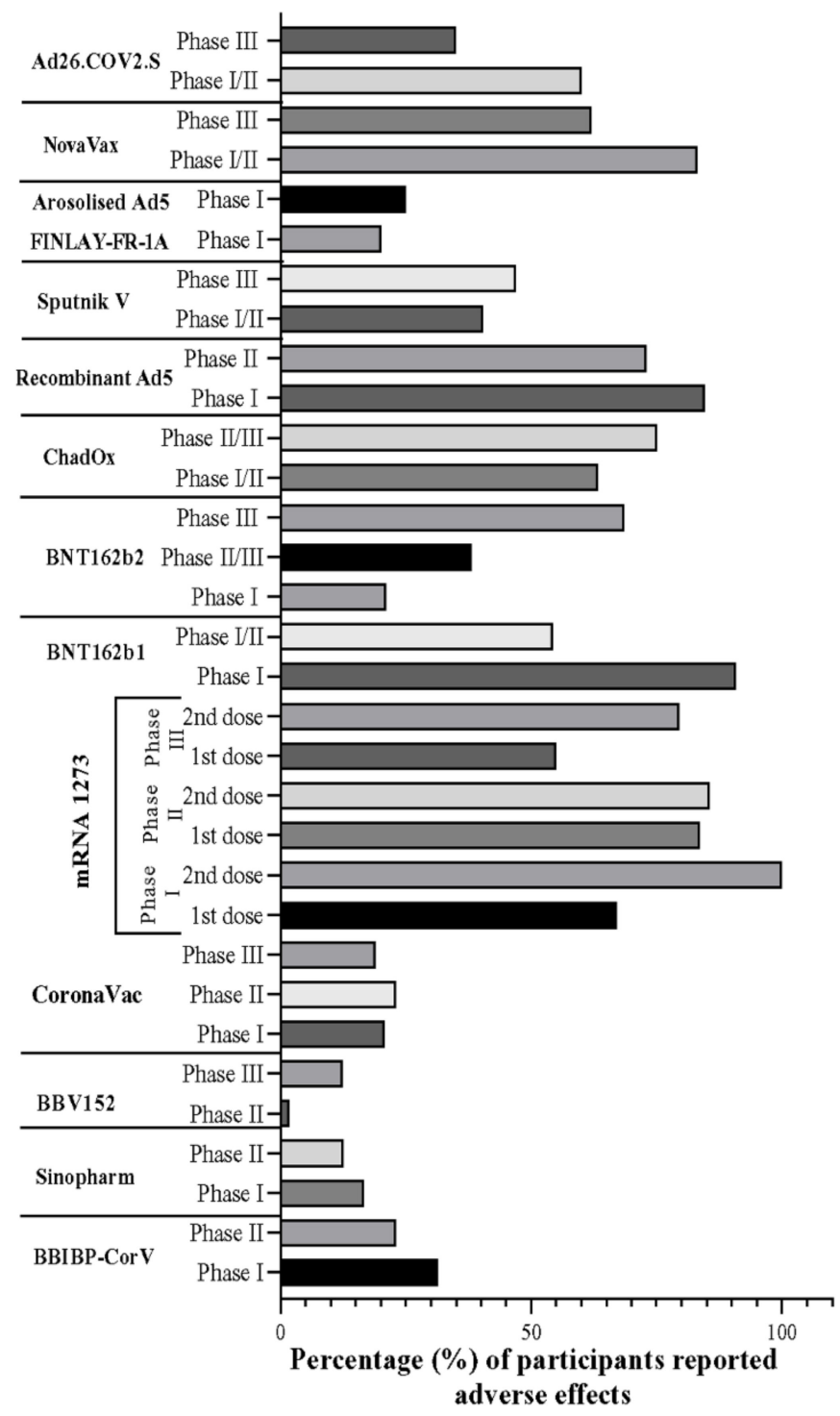

Figure 5. Adverse effects (AE) of several SARS-CoV-2 vaccines by trial phase (i.e., Phase I/II/III), dose number (i.e., 1st or 2nd dose). Data were extracted from the included articles which were selected for this systematic review only.

The trial of the BBIBP-CorV inactivated vaccine was limited by the absence of a longitudinal follow-up study and the assessment of the safety and immunogenicity in children. The vaccine trial was not designed to measure the efficacy of the vaccine [120]. The study of CoronaVac only evaluated humoral response in the Phase 2 trial and did not report immune response data on immunocompromised or more susceptible populations. The comparison of the $\mathrm{Nab}$ titer determined from the trial data with the titer observed in COVID-19 patients was not reported. Only the neutralizing antibody assay was undertaken in older people, which excluded $\mathrm{T}$ cell response observation. The study subjects of the aged group were healthy. Consequently, there were no assessment results about the safety and immunogenicity of the vaccine in immunocompromised people. The longitudinal follow-up result of the participants is yet to be observed [122,123].

The trial of BBV152 was conducted when the number of COVID-19 cases was rapidly increasing. However, the results of the trial did not confirm the evaluation of core vaccine efficacy. Besides, the study population lacked multi-ethnicity and longitudinal reexamination. Several participants reported minor unfortunate adverse reactions to the vaccine during the Phase 2 trial compared to the Phase 1 trial (Figure 5). However, the positive aspect was that it was designed with participants from diverse geographic sites 
and different age ranges. Regardless of their age, no differences were reported in the immune response. After completing the Phase 1 trial, $6 \mu \mathrm{g} \mathrm{Ag}+$ Algel-IMDG formulation was selected for the Phase 3 trial. Because of the current pandemic situation, it received approval for emergency use in India [92]. In the Phase 3 trial of BBV152, 24,419 participants enrolled. It was a double-blind, randomized, and multicenter trial. A total of 24 and 106 cases of COVID-19 were reported in the vaccine and placebo groups, respectively. Overall, the vaccine's efficacy was $77.8 \%$, whereas the vaccine's efficacy against severe symptomatic and asymptomatic COVID-19 cases was $93.4 \%$ and $63.6 \%$, respectively [128].

The trial design of the inactivated vaccine developed by Sinopharm did not include a plan for interim analysis in the original protocol. It was included while conducting the study, which was necessary for designing a Phase 3 trial. Despite producing a robust antibody response, whether the vaccine can provide protective immunity against COVID19 is still unknown. The study result was based on a few groups of patients; hence, the study was unable to provide a comprehensive profile of suitability, immunity, and immune persistence [127]. These ongoing vaccine studies need further evaluation to assess if this vaccine provides long-lived immunity against SARS-CoV-2.

\section{2. $m R N A$ Vaccine}

mRNA vaccine generally consists of the elements essential for the encoded protein to be expressed [129]. In the mRNA vaccine, 1-methyl-pseudouridine modification is incorporated in mRNA molecules, enhancing mRNA translation in the body [130]. The antigen is initially identified from the target pathogen. After sequencing and synthesizing, the gene is usually cloned into a plasmid. Before being delivered into the host, the mRNA is transcribed in vitro. After its injection into the body, it uses the host cellular machinery to translate the mRNA into the target antigen. Commonly, both humoral and cellular immunity are induced as the mRNA vaccine mimics the initial viral infection [131]. Chemokines and cytokines (i.e., IL-12, TNF) are produced at the injection site, generating robust innate immunity [132-134].

Compared to subunit, killed, live attenuated, and DNA-based vaccines, mRNA vaccines are preferred as they are safe and hardly have any harmful risk of infection. Besides, the mRNA vaccine is more stable, easily translatable, rapidly producible, and usually economical [135-139]. The easy availability of mRNA's printing facility plays a crucial role in producing considerable quantities of mRNA that facilitate mRNA vaccine production [140]. The mRNA vaccine's good adequacy and self-adjuvant properties elicit adaptive solid immune responses by releasing TNF- $\alpha$, IFN- $\alpha$, and other chemokines, by immune cells. Polypeptide and protein-based vaccines require additional adjuvants, whereas the mRNA vaccine does not require these. Again, mRNA vaccines express target proteins in the cytoplasm instead of entering the nucleus, making them more efficient than DNA vaccines [141].

In the early 1990s, mRNA vaccines were first identified; however, the production and stability complications did not allow them to advance into therapeutics in the coming years [142]. Later, around 2013, H10N8 and H7N9 mRNA vaccines against H10N8 influenza strain (A/JiangxiDonghu/346/2013) and H7N9 influenza strain (A/Anhui/1/2013) showed a robust humoral immune response in Phase 1 trials, whereby both the vaccines encoded hemagglutinin (HA) glycoprotein [143]. mRNA-based vaccines against HIV, CMV, Chikungunya, and Zika were developed before the COVID-19 pandemic [144]. However, none of these have been approved by the FDA to date. Due to advancements in nucleic acid technologies, their performance has improved in humans in recent years because of their new formulations and modifications [140]. During the current COVID-19 pandemic, Moderna, BioNTech, and Pfizer have launched mRNAbased vaccine candidates.

Moderna and Pfizer/BioNTech developed COVID-19 vaccines by implementing nanotechnology [145-148]. The human body has ribonucleases enzymes present in every tissue and ready to destroy scattered RNA. Ribonuclease creates a restricted environment for foreign RNA, which might originate from plants or animals. Moreover, negatively charged 
mRNA cannot cross the negatively charged cell membrane, making it challenging to restore mRNA integrity and enter the host cell. Researchers designed lipid nanoparticles to carry siRNA or mRNA into host cells. Lipid nanoparticles can be created to encapsulate RNA and shield it from ribonuclease. The lipid nanoparticles also allow passage through the cell membrane. Those nanoparticles can be decorated with ligands that allow targeting certain immune cell types.

Moreover, adjuvants can be added to the interior of the lipid nanoparticles for further upregulation of the immune system's response to the vaccine. Lipid nanoparticle-based technology can be a beneficial solution to challenge RNA delivery to cells [149-156]. Vaccine development by nanotechnology improves nucleic acid delivery and conformationstabilized subunit vaccines to lymph nodes. It triggers cellular and humoral immunity, preventing viral infection and disease severity [157].

The mRNA-1273 vaccine, manufactured by Moderna, encodes SARS-CoV-2's Spike glycoprotein (S-2P antigen). An intact S1-S2 cleavage site and SARS-CoV-2 glycoprotein, along with the transmembrane, were anchored, making up the vaccine. Two successive proline substitutions at amino acid positions 986 and 987 stabilize S-2P on its prefusion conformation. These empowered the assurance of an atomic-level structure for the prefusion adaptation of spikes from endemic and pandemic strains counting HKU1, SARS-CoV, and MERS-CoV. Innovative structure-based vaccine design, modified nucleotides, and delivery methods by lipid nanoparticles are the principal reasons for mRNA-1273's rapid immunogenicity.

The Phase 1 trial of mRNA-1273 on humans was conducted at the Kaiser Permanente Washington Health Research Institute in Seattle and the Emory University School of Medicine in Atlanta. After the first immunization, the day 29 enzyme-linked immunosorbent assay anti-S-2P antibody geometric mean titer (GMT) was found as 40,227 (25 $\mu \mathrm{g}$ group), 109,209 (100 $\mu$ g group), and 213,526 (250 $\mathrm{g}$ g group), where a positive correlation was observed between dose and GMT. After the second immunization, day 57 GMT enhanced up to 299,751 (25 $\mu$ g group), 782,719 (100 $\mu$ g group), and 1,192,154 (250 $\mathrm{g}$ group), respectively maintaining the initial response (Figure 4). However, approximately $21 \%$ of the $250 \mu \mathrm{g}$ dose group had one or more severe unfortunate events (Figure 5) [158].

Significant immune responses to SARS-CoV-2 were reported in patients 18 years and older from the Phase 2 trials, which confirmed immunogenicity and safety of 50 and 100 $\mu \mathrm{g}$ of the mRNA-1273 vaccine. Within 28 days after the first vaccination, anti-SARS-CoV-2 spike binding and neutralizing antibodies were elicited by both doses of the mRNA-1273 vaccine. After the second vaccination, titers peaked by 14 days, which exceeded the COVID19 patient's convalescent sera level (Figure 4). Nevertheless, the Phase 2 trial had some limitations. The study population was not outlined at the time to be representative of those likely to get COVID-19. Statistical comparison of superiority or proportionality between doses was also not included in the study [159].

The Phase 3 trial showed $94.1 \%$ efficacy of the mRNA-1273 vaccine in preventing COVID-19 illness (Figure 3). The reactogenicity profile was similar to the Phase 1 data, and no unexpected concerns were detected. After the first dose of the vaccine, the level of reactogenicity was less than the zoster vaccine that was recently approved. The short duration of follow-up to investigate the safety and efficacy, and lack of any specified correlation of protection, were the drawbacks of the Phase 3 trial [160].

BioNTech and Pfizer manufactured both the BNT162b2 and BNT162b1, where a fulllength spike of SARS-CoV-2 was encoded by BNT162b2. Two proline mutations were carried out to lock its prefusion conformation. As a result, this vaccine mimicked the intact virus and elicited immunity. On the other hand, the receptor-binding domain (RBD) of spike protein was encoded by BNT162b1. Trimerization was carried out by adding a T4 fibritin-foldon domain. Consequently, the immunogenicity was enhanced by the multivalent display. Lipids were used to formulate this vaccine and supplied as a buffered liquid solution $[130,161]$.

The Phase 2/3 trial with the BNT162b1 vaccine was performed among 45 healthy adults, which assessed safety, tolerability, and immunogenicity of BNT162b1 at three dose 
levels (i.e., $10 \mu \mathrm{g}, 30 \mu \mathrm{g}$, or $100 \mu \mathrm{g}$ ). BNT162b1 generated robust immunogenicity after vaccination, where dose levels had a positive correlation with the antibody titer. Moreover, the second dose increased SARS-CoV-2 neutralizing antibody titers and RBD-binding IgG concentrations. The second immunization with $100 \mu \mathrm{g}$ was not administered because of the expanded reactogenicity and a need for seriously increased immunogenicity after a single dose compared with the $30 \mu \mathrm{g}$ dosage. This trial proposed that dose levels between $10 \mu \mathrm{g}$ and $30 \mu \mathrm{g}$ with BNT162b1 might be well-tolerated and immunogenic [130,161].

However, several limitations were noticed. These included the kind, i.e., $\mathrm{T}$ cells versus $\mathrm{B}$ cells or both, and the level of immunity required to ensure protection from COVID-19 was unknown. In addition, the immune responses or safety were not assessed beyond two weeks after the 2nd vaccination. Again, as the study population was only up to 55 years old, the trial could not evaluate the plausible risk factors in the people beyond that particular age range [161,162].

A randomized, placebo-controlled, double-blind Phase 1 study of the BNT162b1 mRNA vaccine was conducted in younger and older Chinese adults to assess the preliminary safety and immunogenicity. This study showed an acceptable safety profile of BNT162b1 [163].

The safety and immunogenicity of three dose levels of BNT162b1 and BNT162b2 were also assessed in a Phase 1 trial on 145 healthy adults. In this trial, BNT162b2 showed less severity and incidence of adverse effects than BNT162b1 while eliciting a similar dosedependent antibody titer, parallel to the GMT of SARS-CoV-2 convalescent patients, or even more in some cases. The reason behind the high reactogenic profile of BNT162b1 compared to BNT162b2 was the difference in their nucleotide sequences by which vaccine antigens were encoded and the overall RNA construct size. As a result, RNA molecules of BNT162b1 were five times higher than the same concentration of BNT162b2, which elicited high immune stimulation and a reactogenic profile. Besides, the lack of knowledge regarding how effective it would be in protecting COVID-19 in a real-world sense was a major limitation of the Phase 1 trial along with the assessment of humoral and cellular immunity in protecting COVID-19. Although the Phase 1 part of this trial evaluated several hypotheses, it was not large enough to allow systematic statistical comparisons and standardized among laboratories. Regarding all these issues, BNT162b2 was subsequently selected for Phase 2/3 safety and efficacy trials [130,161].

Phase 2/3 trials evaluated the safety, immunogenicity, and efficacy of BNT162b2 in preventing COVID-19. Two doses of $30 \mu \mathrm{g}$ BNT162b2 conferred 95\% effectiveness in preventing COVID-19 in patients aged 16 years of age or older and showed safety over a median of 2 months (Figure 3). However, this trial also had several limitations. Unexpected events such as right axillary lymphadenopathy, right leg paresthesia, paroxysmal ventricular arrhythmia, and shoulder injury were reported among BNT162b2 recipients (Figure 5) [94]. The vaccine also required freezing temperature for shipping and more extended storage.

A Phase 3 trial was also conducted to assess the safety, efficacy, and immunogenicity of BNT162b2 in 12- to 15-year-old participants. This study showed that a two-dose regimen of $30 \mu \mathrm{g}$ of BNT162b2 was highly safe and immunogenic for adolescents (12 to 15 years of age) with an efficacy of $100 \%$ [164].

An exciting observation reported in BNT162b2 recipients were those who previously had SARS-CoV-2 infection; the anti-Spike titer increased approximately 140 -fold within 19-29 days compared to those who had not been infected [165,166]. A single dose of this mRNA vaccine enhanced spike protein-specific antibody IgG level, ACE2 receptor binding inhibition reactions, and post-vaccine symptoms in individuals who were previously infected with SARS-CoV-2, similar to the second dose in individuals who were not infected $[167,168]$. Another study suggested that antibodies against SARS-CoV-2 nucleocapsid (N), RBD, and spike proteins (i.e., S1 and S2) were raised after the single dose of mRNA vaccine in those who were already seropositive or had a recent history of infection as compared to individuals with no history [169]. 


\subsection{Viral Vector-Based Vaccine}

In a viral vector-based vaccine, a gene/cDNA coding for a pathogen-derived antigen is incorporated into a non-pathogenic or attenuated viral species [170]. These non-pathogenic species serve as a vector. The recombinant vector immunizes against the pathogen while the gene product is expressed on its surface. For this purpose, a few sites are removed from the vector genome where the targeted pathogen's foreign DNA can be integrated. After injecting, that foreign DNA can replicate within the host and express the following pathogen's gene product, eliciting cell-mediated and humoral immunity. Different viruses, including adenovirus, vaccinia virus, canarypox virus, and attenuated poliovirus, act as viral vectors. Among them all, the adenovirus is relatively conventional in vaccine formulation [170,171].

Adenoviruses contain a distinctive icosahedral protein structure that encapsulates a linear double-stranded DNA genome of 36k base pairs. The viral genome has approximately a dozen capsid proteins without any lipid envelop and encodes nearly 35 proteins elicited in two phases, "early" and "late," related to viral DNA replication [172]. Different types of adenoviral serotypes are separated from a variety of mammalian species. There are approximately 51 serotypes from humans, 27 from simians, and 7 from chimpanzees. Human serotypes are subdivided into six subgroups [173]. They are responsible for various clinical diseases that commonly infect the gastrointestinal and respiratory systems [174]. More than one serotype could be accountable for mild infection in most immunocompetent individuals, which is supposed to render lifelong immunity [172].

There are several distinctive features reflected by adenoviruses, making them a suitable option for vaccine formulation. Firstly, recombinant adenoviruses have a better safety record when used as a vector for gene therapy in humans. Because of its extensive tissue tropism ability, adenoviral vectors are supposed to exploit vaccine development against $M$. tuberculosis and influenza. Secondly, adenoviruses are highly immunogenic, driving up a strong and long-lasting immune response. For vaccine design purposes, human serotype 5 adenoviruses (AdHu5) are used broadly, while other non-human adenoviruses are also used in modern times. The adenoviral genome encodes five early proteins (E1a, E1b, E2, E3, and E4) responsible for DNA replication and evasion and a single late protein responsible for structural conformation. Removing the E1a gene (critical regulator of viral replication) from the adenoviral genome eliminates the virus's ability to replicate, simultaneously increasing the potency to accommodate transgene cassettes up to $5000 \mathrm{bp}$ in size. Deleting multiple genome units can augment the vector capacity for yielding multivalent vaccines against deadly pathogens [175].

Recombinant adenoviral vector vaccine trials were undertaken during the MERS-CoV epidemic. Dromedary camels were an animal reservoir of MERS-CoV. Two recombinant adenoviral vector vaccines, Ad5.MERS-S and Ad5.MERS-S1, were designed to generate an immune response against dromedary camels to eradicate MERS-CoV transmission from the reservoir to humans. Ad5.MERS-S encoded full-length $S$ protein of MERS-CoV, and other Ad5.MERS-S1 encoded S protein's S1 extracellular domain. Both vaccines immunized BALB/c mice and generated effective immunity [176].

BVRS-GamVac-Combi vaccine was manufactured by NF Gamaleya Research Institute of Epidemiology and Microbiology against MERS-CoV, where recombinant human adenoviruses 26 and 5 serotypes were used. Both vectors encoded the glycoprotein of the MERS-CoV. This vaccine immunized mice of C57BL/ 6 strain and common marmoset [177].

During the COVID-19 pandemic, the Beijing Institute of Biotechnology and CanSino Biologics manufactured the Ad5 vector COVID-19 vaccine. The replication-defective Ad5 vector vaccine encodes spike glycoprotein. Based on Wuhan-Hu-1 (GenBank accession number YP_009724390), an optimized full-length spike gene was cloned with tissue plasminogen activator signal peptide gene and E1 and E3 deleted Ad5 vector, resulting in an Ad5 vector COVID-19 vaccine developed utilizing the Admax system. It was manufactured as the liquid formulation in a vial containing $5 \times 1010$ viral particles $/ 0.5 \mathrm{~mL}$. The Phase 1 trial found that the vaccine is tolerable and immunogenic after 28 days of vaccination. 
From day 14 of immunization, rapid $\mathrm{T}$ cell responses were remarkable. Humoral immune responses peaked at day 28 of immunization. The Phase 2 trial showed a $5 \times 1010$ viral particles dose as safe for vaccination. Significant immune responses were induced after a single immunization. The short duration of follow-up, small cohort size, and absence of randomized control groups limited the findings from the Phase 1 trial. The study was also not statistically powered to assess the level of any side-effects. The Phase 2 trial, too, also presented some limitations. The problems began as the study started before complete data analysis from the Phase 1 study was accessible. Consequently, it failed to show the difference between different dosage groups. Children were also not included in this trial $[178,179]$.

The Institute of Biotechnology, Academy of Military Medical Sciences, PLA of China, developed an aerosolized adenovirus type-5 vector-based COVID-19 vaccine (Ad5-nCoV). The Phase 1 trial was performed at Zhongnan Hospital to evaluate the vaccine's safety, tolerability, and immunogenicity administered via inhalation. This study showed that aerosolized Ad5-nCoV is painless, simple, well-tolerable, and an aerosolized dose-induced antibody and cellular immune responses are equal to a fifth of the usual injected dose [180].

Among several candidate vaccines, the three most promising adenoviral vector-based vaccines have been going through clinical trials to ensure the host's safety, efficacy, and immunogenicity while inducing an immune response. Adenoviral vector combined with DNA and poxviral vector to induce immunogenicity showed cellular and humoral response enhancement. The Oxford/AstraZeneca vaccine contains a homologous adenoviral vector that could mitigate the efficiency of the second dose due to anti-vector immunity. The "chimpanzee adenovirus" was an excellent vector for vaccine formulation from previous vaccine preparations against MERS-CoV. The Phase 1 clinical trial showed promising results, maintaining potency and protecting non-human primates against MERS-CoV. ChAdOx1 MERS exhibited safety and efficacy, which expressed cellular and humoral immune responses at the highest dose $\left(5 \times 10^{9}\right.$ viral particles $)$.

The Oxford/AstraZeneca vaccine is an adenoviral vector-based vaccine comprising DNA that encodes surface glycoprotein protein embedded in a capsid from a modified chimpanzee adenovirus, ChAdOx1 (replication-deficient simian adenovirus vector). A single vaccination with $\mathrm{ChAdOx} 1 \mathrm{nCoV}-19$ into rhesus macaques showed potent humoral and cellular responses in a preclinical trial stage. A high-dose vaccination into a nonhuman primate showed protection against lower respiratory tract infections. After the Phase $1 / 2$ clinical trial, the ChadOx1 nCoV-19 vaccine showed anti-spike IgG response, early T-cell response, and neutralizing antibody response, which illustrated an admissible safety profile with an enhanced humoral and cellular response. Vaccinated participants presented different amounts of immune cell clusters of B-cells, T-cells, and NK cells. Strong activated B-cells are found, and anti-spike IgG and IgA antibodies against SARS-CoV-2 spike protein were identified from vaccinated individuals. Identical CD4+ and CD8+ T-cell patterns were observed, responsible for the expression of CD69 and Ki-67, between days at 7 and 28 after vaccination. Production of cytokines (TNF- $\alpha$ and IFN- $\gamma$ ) by CD4+ T-cells was also identified on day 14 after immunization. On the other hand, NK cells expressed cytotoxic activity against viral infection at the highest rate at day $28[93,181]$.

A published report showed that a booster dose is more efficient in inducing multifunctional antibody titers with different types of effector mechanisms, including antibodydependent neutrophil/monocyte phagocytosis, natural killer (NK) cell degranulation, complement activation, and cellular phagocytosis against SARS-CoV-2 infection. Strong T-cell responses have also been delineated, in which highly activated cytotoxic T-cells destroy virus-infected cells to stop the further cell-to-cell spread of the virus. On the other hand, helper T-cells play a supporting role in activating B-cells for frequent antibody production. The booster dose is less reactogenic compared with the priming dose. Local and systemic reactions were consistently reduced after the second dose (Figure 5). A booster dose necessitates its importance in the restoration of sustainable immunity [182]. 
The Phase 3 trial of the ChadOx $1 \mathrm{nCoV}-19$ vaccine has shown improved findings, with the vaccine being more well-tolerated and efficient $(70.4 \%)$ in older than younger adults and similarly immunogenic for all age groups [183]. A well-accepted safety and efficacy profile of AZD1222 (ChadOx1 nCoV-19) has been established after analyzing ongoing trials in Brazil, South Africa, and the UK, making it an efficient and robust candidate vaccine against SARS-CoV-2 globally (Figures 3 and 5) [184]. Epidemiologic efficacy of the Oxford/AstraZeneca ChAdOx1 nCoV-19 vaccine against the B.1.351 variant was 10.4\% (95\% CI, -76.8 to 54.8). However, the vaccine effectiveness against the B.1.1.7 variant was comparatively higher than the exhibited efficacy of $70.4 \%$ (95\% CI 43.6-84.5) for B.1.1.7 and 81.5\% (67.9-89.4) for non-B.1.1.7 lineages. However, the neutralization activity of ChAdOx1 $\mathrm{nCoV}-1$ decreased in the B.1.1.7 variant compared to the non-B.1.1.7 variant $[185,186]$.

Mutations in the RBD and N-terminal domain (NTD) of the SARS-CoV-2 spike gene are the major concern for vaccine development in recent pandemics [186]. RBD mutations (N501Y mutation) are responsible for increasing affinity to the ACE-2 receptor. On the other hand, E484K and K417N RBD mutations and mutations in NTD are accountable for escaping from the neutralizing antibody response. The B.1.1.7 lineage, first identified in the UK, contains the N501Y mutation with 53\% increased transmissibility. Another mutated clan, named B.1.351, identified in South Africa, includes three RBD mutations and five NTD mutations. An independent lineage found in Brazil also adopted E484K, K417N, and some B.1.351 mutations [186].

An individual analysis of the Oxford/AstraZeneca vaccine against B.1.351 (South African variant) was undertaken between 24 June and 9 November 2020, where 2026 participants were enrolled. The T-cell response was not effective. Thereby, significant portions of viral antigens of B.1.351 variants remained flawlessly active. Furthermore, the vaccine failed to show a protective immune response against the B.1.351 variant, whereby the vaccine efficacy against the variant was $10.4 \%$ (95\% CI, -76.8 to 54.8) [186].

Sputnik V, a heterologous adenoviral vector-based vaccine manufactured by Gamaleya Research Institute, was designed with two recombinant adenovirus vectors, adenovirus type 26 (rAd26) and adenovirus type 5 (rAd5), and both contain full-length glycoprotein $S$ [187]. rAd26 vector was previously used for different vaccine candidates, such as Ad26.ZE.BOV against Ebola virus; Ad26.Mos.HIV, Ad26.Mos4.HIV, and Ad26.ENVA.01 against HIV; Ad26.CS.01 against Malaria; and Ad26.ZIKV.001 against Zika. These candidate vaccines are being tested, and clinical studies are still ongoing [188-192].

Sputnik V vaccine was developed in two versions, i.e., frozen (Gam-COVID-Vac) and lyophilized (Gam-COVID-Vac-Lyo). The Gam-COVID-Vac study took place at the branch of Burdenko Hospital, and the volunteers who took part in this study were military personnel and civilians. The study of Gam-COVID-Vac-Lyo was undertaken at Sechenow University, and all volunteers were civilians [187]. The vaccine showed strong immune response and protection in non-human primates against SARS-CoV-2 and displayed 100\% defensive measure against a lethal version of SARS-CoV-2 in a preclinical study with immunosuppressed hamsters.

After the Phase 1/2 trials, Sputnik V showed T cell responses in healthy adults and decent titers of neutralizing antibodies. Collective data exhibit higher immunogenicity with robust cellular and humoral immune responses, resulting in higher antibody titers in vaccinated participants than the individuals with convalescent plasma [187].

The Phase 3 trial took place at 25 hospitals and polyclinics in Russia. The GamCOVID-Vac trial showed 91.6\% efficacy against COVID-19 and 100\% protection against severe COVID-19 (Figure 3). In this trial, people 60 years or older were given importance in the vaccine-inducing immune response's protection measures and efficiency. Results showed the ability to induce a virus-neutralizing humoral reaction in 60-year-old individuals. Vaccine efficacy did not alter significantly in young adults and old-age vaccinated participants. However, all risk groups, including children and pregnant women, were not enrolled in the Phase 3 trial. The vaccine is developed in liquid form (stored at $-18^{\circ} \mathrm{C}$ ), and the freeze-dried (held at $2-8{ }^{\circ} \mathrm{C}$ ) formulation is helpful in the distribution 
of vaccines in different weather conditions globally. The Phase 3 clinical trial showed a compatible safety profile and robust immune responses in all age groups from young to old participants (Figures 4 and 5) [193]. The Phase 3 trial showed the sputnik vaccine required two doses to reach $91.6 \%$ efficacy, with a $79.4 \%$ efficacy after one dose as emergency administration $[187,193]$.

FINLAY-FR-1A, a recombinant dimeric RBD-based vaccine manufactured by a Cuban epidemiological research institute, Finlay Institute, against COVID-19, showed a safe and reactogenic outcome in the Phase 1 trial (Figure 5). Secondary outcomes evaluated vaccine immunogenicity. One week after vaccination with a single dose, antibody response enhanced more than 20-fold compared to the Cuban convalescent serum panel's median [194].

VXA-CoV2-1, developed by Vaxart, is an attractive recombinant vaccine candidate against SARS-CoV-2 and is an oral vaccine formulation. The preclinical trial of this vaccine was conducted in 6- to 8-week-old female Balb/c mice. Due to the mice's inability to swallow pills, they were injected with $20 \mu \mathrm{L}$ of the vaccine formulation. Two types of recombinant vaccine formulations, rAd-S-N (vector that expresses $\mathrm{S}$ and $\mathrm{N}$ protein) and rAd-S1-N (vector that expresses a fusion protein of S1 domain and $\mathrm{N}$ protein), were assessed. The former was selected for GMP manufacturing, as it induced a higher immune response, including vaccine-induced T cell response and the production of IFN- $\gamma$, TNF- $\alpha$, and IL-2 CD4+ T cells. This vaccine candidate presents several advantages. Because it is an oral formulation, this makes it more accessible, as it is easier to administer. It is also easier to store, being an oral tablet vaccine, eliminating the need for cold storage transport and holding it in a refrigerator once delivered. Another advantage of this vaccine candidate is it is safe [195].

Another promising candidate vaccine is Ad26.COV2.S, manufactured by Janssen Pharmaceuticals. Ad26.COV2.S utilizes a recombinant, replication-deficient adenovirus serotype 26 (Ad26) vector encoding a stabilized SARS-CoV-2 spike (S) protein educed from the first clinical isolate of the Wuhan strain (Wuhan 2019; whole-genome sequence, NC_045512). Ad26 vector-based vaccines are usually safe and highly efficient and are also being used in the Sputnik V vaccine $[187,196]$.

The Ad26.COV2.S vaccine has been tested in adult and aged rhesus macaques dividing into one- and two-dose regimens to evaluate the protective immune response and efficacy. A two-dose Ad26.COV2.S regimen promoted an ascending neutralizing antibody response compared to a single-dose regimen. However, neutralizing antibody responses were stable for a minimum of 14 weeks in one-dose regimens of the Ad26.COV2.S vaccine, and it also upregulated the humoral immunity and Th1 cellular responses in aged NHP [197].

Eight hundred five healthy adults have been assigned for participating in a Phase 1-2a trial of the Ad26.COV2.S vaccine. In the trial, cohort 1 belongs to participants aged $18-55$ years, and cohort 3 belongs to 65 years or older-aged participants. A single dose of the Ad26.COV2.S vaccine elicited both neutralizing antibody and spike-binding antibody responses in $90 \%$ of participants on day 29 and reached $100 \%$ at day 57 with an increase in the titer. In addition, the CD4+ T-cell responses were found in $76-83 \%$ of participants in cohort 1 and $60-67 \%$ of those in cohort 3 . On the other side, strong CD8+ T-cell responses were detected in all participants but at a comparatively lower level in older individuals than in younger [196].

The Phase 3 trial demonstrated the efficacy of a single dose of the Ad26.CoV2.S vaccine. A total of $67 \%$ and $66 \%$ efficacy was shown in participants against moderate to severecritical COVID-19 disease with an onset at least 14 and 28 days after vaccine administration, respectively. The vaccine efficacy was $76.7 \%$ and $85.4 \%$ for severe-critical COVID- 19 with onset at days 14 and 28, respectively. Reactogenicity was higher with the vaccine group, but a casualty of adverse events was not serious in the vaccine group. Overall, a single dose of Ad26.COV2.S is protective against symptomatic and asymptomatic SARS-CoV2 infections and effective against severe/critical disease to reduce hospitalization and 
death. The Janssen adenovirus virus vaccine against B.1.351 variant has shown a 57\% efficacy [198].

\subsection{Nanoparticle-Based Peptide Vaccine}

Nanotechnology has played an influential role in vaccine development with variations based on nanoparticles' different compositions, shapes, sizes, and surface properties. Nanoparticles, being smaller in size, can quickly enter into living cells through endocytosis $[80,199]$. Different types of nanoparticles are being used in vaccine development, including polymeric nanoparticles, inorganic nanoparticles, liposomes, immune-stimulating complex (ISCOM), virus-like particles, self-assembled proteins, and emulsions [199-201]. Nanoparticles are most commonly used as immunostimulants or delivery materials. In vaccine formulation, the association between nanoparticles and antigens is essential. Nanoparticles act as a temporary carrier and protector of the antigen, which needs to reach the desired location. By interacting with the antigen, nanoparticles enhance immunogenicity and antigen processing, which activate immune responsive pathways [200,201].

Nanotechnology-based vaccine mechanisms are highly efficient, whereas solid nanocarriers transport the core antigen portion of vaccines into the gut-associated lymphoid tissues and mucosa-associated lymphoid tissues, ensuring proper delivery through oral or mucosal routes. Core particles are taken up by the dendritic cells and macrophages, which improve the cellular uptake of antigens and upregulate the antigen recognition and presentation. Nanoparticles are coated with immune cell-targeting molecules that bind with the cellular receptors to stimulate the specific and appropriate immune response [72,77,201-205]. However, no contextual and relevant results have yet been published regarding nanotechnology-based vaccines since the outbreak of severe acute respiratory syndrome (SARS-CoV) and middle-east respiratory syndrome (MERS-CoV) other than the current COVID-19 pandemic [206].

In this ongoing SARS-CoV-2 pandemic, a subunit vaccine (NVX-CoV2373) has been developed using full-length glycoprotein $S$ and administered with Matrix-M adjuvant into non-human primates and mice models, spurring Th1-dependent B- and T-cell responses, production of hACE2 receptor blocking antibodies, and SARS-CoV-2 neutralizing antibodies. No vaccine-related adverse effects were reported in mice models, which encouraged further clinical development of NVX-CoV2373 against COVID-19 [207].

Researchers fabricated a modified "spike gene" of SARS-CoV-2 and installed it into baculovirus, which can only infect insects. Hence, selective moth cells were chosen and infected with the recombinant baculovirus. Consequently, the infected cell started to produce spike proteins assembled to form full-length spike protein similar to SARS-CoV2. After that, spike proteins were purified and fixed with nanoparticles, which were used as a vaccine. Before being mixed with adjuvant distilled from soapbark plants, this vaccine attracted the immune cells to the injection site and activated the solid immune response to nanoparticles. Antigen-presenting cells (APC) uptake and present the spike nanoparticles on its membrane to T lymphocytes via major histocompatibility complex (MHC). T lymphocytes activate the antibody-producing B cells. A different type can be started by APC, called a killer T cell, which can recognize coronavirus-infected cells and destroy them before the further proliferation of new viruses [207,208].

In Phase 1/2 trials, 131 healthy adults of different age groups participated in two-dose regimens and were administered with $5 \mu \mathrm{g}$ and $25 \mu \mathrm{g}$ of rSARS-CoV- 2 with or without the Matrix-M1 adjuvant. Considerable safety results and the ability to induce immune responses with higher amounts of neutralizing antibodies were found in groups with adjuvant compared to groups without adjuvant. After the second vaccination with a similar dosage, the antibody response in participants had surpassed compared to the convalescent serum from COVID-19 patients. This report expresses the advantage of Matrix-M1 in the case of accelerating the functional antibody and T-cell response. No serious local or systemic adverse events occurred with the vaccinated groups. Body pain, joint pain, and fatigue were the most common systemic events that have been reported after the Phase 1/2 trial (Figure 5) [209]. 
A total of 15,187 participants were included in the Phase 3 trial of NVX-CoV2373, which was found to be $89.7 \%$ effective against both B.1.1.7 and non- B.1.1.7 variants. This B.1.1.7 variant is more transmissible and infectious than the previous strains. The vaccine efficacy of NVX-CoV2373 was higher than that of the ChAdOx1 nCoV-19 vaccine (Oxford/AstraZeneca) $(70.4 \%)$ after the Phase 2-3 trial. The NVX-CoV2373 vaccine exhibited a lower efficacy level $(51.0 \%)$ against the B.1.351 variant $[185,208]$ (Figure 3). Scientists suggested that the NovaVax can be effective for a long time and prevent future coronavirus infections. It is easy to store for a long time at $4{ }^{\circ} \mathrm{C}$, making it convenient to transport [208].

\section{Efficiency of Vaccines Observed after Phase 3 Trial}

The efficiency of some of these vaccines was assessed in participants with various conditions. The Phase 4 trial of CoronaVac included participants with autoimmune rheumatoid arthritis (ARD) and a healthy control group. The outcome showed that anti-SARS-CoV-2 IgG seroconversion (SC) and neutralizing antibody $(\mathrm{NAb})$ positivity was reduced six weeks after the second dose by $\geq 15 \%$. The SC and Nab response was lower in the ARD group than in the control group [210].

In a study of CoronaVac, it was seen that the vaccine is capable of inducing immunogenicity in $63.8 \%$ of the study population who have cancer (solid organ tumor) and $59.5 \%$ of the people with cancer and also receiving at least one cytotoxic chemotherapy [211]. Lower antibody responses were found in another study of participants aged 65 years and older, and $51.1 \%$ of the total study population had at least one comorbid disease. There was a significant difference in the mean antibody titer of participants with at least one comorbid disease. Mean antibody levels decreased with decreasing age and comorbid disease [212] The vaccine could not produce detectable antibody responses in hospital workers with immune-mediated disease (IMD) and people aged 65 years and older. Participants who were taking immunosuppressive drugs were significantly less likely to produce antibodies [213]. However, another study compared antibody response to the vaccine in previously infected and uninfected healthcare workers. The outcome suggests that the vaccine is capable of eliciting higher antibody responses in previously infected participants [214]. In a case-control study of CoronaVac during an epidemic of COVID-19 associated with the gamma variant in Brazil, it was seen that the vaccine reduced hospital admission and death in participants aged $\geq 70$ years. Vaccine-induced protection was higher in participants who completed two doses, and the vaccine's efficacy declined with increasing age [215]. Another study concluded that CoronaVac produced a lower neutralizing antibody response against alpha and gamma variant than D614G variant in participants who received two vaccine doses [216].

In an interesting observational case study in Bahrain, a family showed that two participants who had taken two different vaccines were in contact with COVID-19 patients who did not show any symptoms. As a response to the study, the country started giving boosters of the Pfizer vaccine to Sinopharm vaccine recipients. It concluded that the Sinopharm vaccine does not prevent people from getting infected [217]. Another study of the Sinopharm/BBIBP-CorV vaccine showed that the vaccine could induce an antibody response in $95 \%$ of participants, although the seroconversion rate was lower in older individuals ( $>60$ years). The vaccine generates the same level of antibody response against B.1.617.2, B.1.351, and ACE-2 receptors, as seen in the case of natural infection [218].

Although the antibody titer produced by BBV152/Covaxin is low for the annulment of beta and delta variants, its neutralization potential is well established; 97.8, 29.6, and 21.2 GMT titers were found in recovered cases of B1, Beta, and Delta variants [219]. Another study demonstrated that Covaxin was able to induce protection against the B.1.1.7 variant [220].

An observational study was conducted in Israel residents aged 16 years and older following a nationwide vaccination campaign using national surveillance data to assess the real-world effectiveness of two doses of BNT162b2 against various SARS-CoV-2 outcomes and evaluate the public health impact. The effectiveness of the vaccine was $95.3 \%$ against 
SARS-CoV-2 infection, 91.5\% against symptomatic COVID-19, 97.2\% against COVID-19related hospitalization, and $96.7 \%$ against COVID-19-related death at 7 days or longer after the second dose, where the B.1.1.7 SARS-CoV-2 variant was the dominant strain [221].

Another population study in Qatar showed that the mRNA-1273 vaccine is highly effective against infection induced by B.1.1.7 (Alpha) and B.1.351 (Beta) variants. The vaccine's effectiveness against B.1.1.7 and B.1.351 variants was $81.6 \%$ and $95.7 \%$ after the first and second dose [222].

A case-control study was conducted in the population of Qatar to assess the real-world effectiveness of the BNT162b2 (Pfizer-BioNTech) and mRNA-1273 (Moderna) vaccines against the Delta (B.1.617.2) variant. At $\geq 14$ days after the second dose, effectiveness against the Delta variant was $89.7 \%$ for BNT162b2 and 100.0\% for mRNA-1273 [223].

Another study showed that the BNT162b2 COVID-19 vaccine elicits robust SARS-CoV2-S antibody and T cell responses in nursing home residents (NHR) Clínico-Malvarrosa Health Department, Valencia (Spain). In SARS-CoV-2 naïve NHR, the seroconversion rate was $95.3 \%$, similar to controls $(94.4 \%)$ [224].

A further study among hemodialysis patients observed that poor immunogenicity was generated at 28 days after a single dose of BNT162b2. Consequently, the second dose should be administered without any delay in this population [225]. Further research has also suggested that this vaccine is safe for youths and young adults having a previous history of acute lymphoblastic leukemia and allergy to PEG-asparaginase [226].

\section{Overall Comparison of Vaccine Candidates in the Trial Phase}

According to the studies, all the reported vaccine candidates based on inactivated, mRNA, recombinant, and nanoparticle-coupled strategies showed promising efficacy (Figure 3). The seroconversion and the neutralizing antibody titers were observed in almost every trial for each vaccine candidate, where the seroconversion mainly started from days 7-14. In nearly every Phase 2 and 3 trial, the overall seroconversion rate was approximately $80-100 \%$ (Figure 4 ). However, one or more unwanted events comprising both the systemic and local systems were reported in every phase of trials for all registered vaccine candidates (Figure 5). Among mRNA-based vaccine candidates, the mRNA-1273 vaccine was reported to have a higher rate of unpleasant events than the other. ChadOx and recombinant Ad5 assisted in developing more frequent side effects in recombinant vaccines than Sputnik V and FINLAY-FR-1A. The nanoparticle-based vaccine candidate showed numerous immunogenic events (>80\%) (Figure 5).

\section{Gender-Based Adverse Events of COVID-19 Vaccines}

Some concerns have been raised about the safety of the COVID-19 vaccines. For example, it was suggested that the vaccines could have an impact on pregnancy and damage fertility. In particular, mRNA vaccines were claimed to be cross-reactive with the human placental protein syncytin, potentially causing placental damage. However, these were unfounded speculations. Vaccines are completely safe during pregnancy and provide excellent protection for the baby. Pregnant women should be urged to acquire COVID-19 vaccines because they are also at risk of becoming infected during pregnancy [144,227-229]. During trials, pregnant people were excluded, and participants were strictly asked to avoid getting pregnant. However, 57 pregnancies were found across the trials of the three most highlighted vaccines that have been approved in the UK. After completing the trials, $0 \%$ miscarriage results were found in both the Moderna and Pfizer/BioNTech vaccines, and $2 \%$ accidental miscarriages were found in patients receiving the Oxford/AstraZeneca vaccine, which is small compared to control groups. This report indicates that vaccines do not have any harmful effects on early pregnancy and do not restrain pregnancy in humans [227,230-232].

After vaccination, adverse events (AEs) have been reported across all age groups above 18 years old. However, adults aged 65 and above reported more serious AEs (SAEs) when compared with the 18 to 64 years old group, which included deaths and 
dyspnea. In contrast, most of the AEs reported by the 18 to 64 age group were not serious in nature. Moreover, it has been noted that, when compared to females, males are more likely to experience SAEs, while females are more likely to report AEs compared to males. The majority of the AEs were recorded within one week of the initial dose. Overall, the vaccine developed by Pfizer and BioNTech has resulted in more AEs. Approximately 10\% of the reports were serious, with $2 \%$ of them involving death, with the majority being in patients aged 65 years and above. Additionally, among the $20 \%$ of the subjects who visited the ER, more than 5\% were involved with hospitalization, while $10 \%$ were involved with office visits. Headache, fatigue, dizziness, chills, pyrexia, nausea, pain, injection site pain, and pyrexia were among the top ten non-serious AEs following COVID-19 immunization [233].

In another study, thirty-two thousand forty-four subjects from VigiBase were assessed to evaluate SAEs associated with various COVID-19 vaccines based on age, gender, and the severity of the adverse events. Among these subjects, $80 \%$ were females. A total of 103,954 adverse events, at a rate of 3.24 AEs per subject, were reported. Furthermore, among the total AEs reported, 28,799 (27.7\%) AEs from 8007 subjects were recorded as SAEs. The majority of SAEs were seen in Europe (83\%) among females aged between 18 and 64 years $(80.74 \%$ ). Vaccination with BNT162b2 (Pfizer) was linked to the majority of SAEs (74\%) recorded. General illnesses (30\%) were the most common SAEs, followed by the nervous system (19.1\%) and musculoskeletal $(11.2 \%)$ disorders on a system-wise classification. Individually, headache $(8.1 \%)$ was the most prevalent ailment, followed by pyrexia $(7 \%)$ and fatigue (5.1\%). According to a clinical trial linked to the Moderna vaccine, SAEs accounted for 26.73 percent of all AEs recorded in the VigiBase, with death occurring in $1.23 \%$ of all SAEs. As per the analysis, myocardial infarction $(0.03 \%)$, cholecystitis $(0.02 \%)$, and nephrolithiasis $(0.02 \%)$ were the most prevalent SAEs reported. The number of serious adverse events (SAEs) reported with the various vaccines was lower than the non-serious ones, and the death rate was low among all vaccines. Overall, female vaccine recipients reported more local symptoms, such as injection site discomfort, redness, and swelling, as well as certain systemic events, such as joint pain, myalgia, headache, back pain, abdomen pain, fever, chills, and hypersensitivity reactions, than male vaccine recipients [234].

During vaccination with ChAdOx $1 \mathrm{nCoV}-19$, a minority of the participants $(n=13)$ reported thrombosis as an $\mathrm{AE}$, which led to the halting of the vaccination program. Sinus and/or cerebral vein thrombosis were noticed in those individuals after the vaccination. However, prior to the vaccination, these individuals were preoccupied with thrombocytopenia, which would have probably led to the immunological cascade eventually causing thrombosis [235,236]. According to the Society of Thrombosis and Haemostasis Research (GTH), such a phenomenon may occur due to the induction of antibodies after vaccination, which may react against platelet antigens, ultimately creating a massive activation of platelets via the Fc receptor that either may be independent or dependent on heparin. However, it is to be noted that the vaccination program was restarted due to a lack of strong correlation between the ChAdOx1 nCoV-19 vaccine and thrombosis. Furthermore, it was also stated that individuals are more unlikely to develop thrombosis after vaccination, though several guidelines have been put in place if any such untoward major incident may arise [236].

\section{Importance of the Integration of Diagnostic Assays Pre- and Post-Vaccination}

Phase 3 trials measure the efficacy of a vaccine by assessing how well it works based on double-blinded placebo-controlled trials $[67,237,238]$. The efficacy of vaccines is based on patients' susceptibility and chances of developing infection [239]. RT-PCR is used to detect reinfection cases after vaccination. Mass testing with highly sensitive rapid antigen testing (RAT), capable of detecting COVID-19 infection in the acute phase, is crucial in monitoring reinfection cases post-vaccination [240-242]. Vaccine antigen-specific sero-monitoring and memory T/B-cell persistence are also essential determinants for the requirement of booster doses and epitope modification in vaccine designing. 
Another method for determining vaccine efficiency is serological testing. Seroconversion after vaccination indicates that protective immunity has been activated in the vaccinated host [243]. The rapid diagnostic test (RDT), enzyme-linked immunosorbent assay (ELISA), chemiluminescence immunoassay (CLIA), and neutralization assay are the different types of serodiagnostic tests that can be employed to identify seroconversion, persistence, and longitudinal dynamics of both the neutralizing and non-neutralizing antibodies [186,244-251]. Besides, serological testing is crucial for immuno-compromised or autoimmune patients, who generally have altered immune responses [252-254]. However, activation of cell-mediated immunity (CMI) without humoral immunity post-vaccination in a few cases elucidates the importance of assays detecting both cell-mediated immunities as well as humoral immunity in testing the activation and waning effects of a vaccine. Thus, integrating diagnostic assays with the vaccination program helps identify the vulnerable population who requires booster doses and assesses vaccines of different strategies for their requirements and frequencies of booster shots.

\section{Mix-and-Match Approach}

The worldwide distribution, proper management, and shortages of vaccines of the same brand in different countries are a concern. To address this and potentially enhance responses, tactics including the "mix-and-match" approach are under trial. Here, the heterologous vaccination of two different types of vaccines is administered as prime and booster doses, respectively. This strategy is not entirely a novel idea, as such heterologous vaccination methods have been applied previously for HIV and Ebola [255]. In the case of the SARS-CoV-2 vaccine, a few heterologous approaches have already been studied in different countries. Heterologous combinations such as recombinant (ChAdOx1 nCoV-19) and mRNA (BNT162b2), inactivated (CoronaVac), and recombinant (ChAdOx1 nCoV-19), as well as inactivated (BBIBP) and mRNA (LPP-spike-mRNA), have been studied. To date, a significant augmentation of anti-spike antibody memory $B$ and $T$ cell responses with a few mild side effects, including headache, chills, and fatigue, have been observed [256-260]. Currently, a thorough evaluation of the homologous and heterologous prime booster of COVID-19 vaccines is underway.

\section{Genomic Surveillance and Vaccine Up-Gradation}

Many people were initially reluctant to be vaccinated as COVID-19 vaccines were rapidly developed [261,262]. Ideally, researchers aim to develop a single dose-based vaccine that is highly effective. However, it is challenging, as different types of vaccines present different immunoreactivity pathways based on host factors such as persistence of protection, co-morbidities, and ethnicity. Furthermore, the efficacy of different types of vaccines in providing protection depends on the emerging variants of SARS-CoV-2, some of which can evade the immune system. Previously, E848K escape mutation of SARS-CoV-2 and other mutations were reported in different countries through the next-generation sequencing (NGS) method [263-267]. The recent concern about reinfection by the new lineage P.1 (alias of B.1.1.28.1) of SARS-CoV-2, similar to the lineage B.1.1.28, evolved in Brazil or Bengal variant in West Bengal B1.1.618, is a puzzling phenomenon for the vaccination process [268]. Inclusion of several mutations of an amino acids (i.e., S: E484K, S: K417T, and S: N501Y) might work as the means to address the question of inadequacy of vaccines in providing extended protection in the case of immune escape mutations [269]. Vaccine manufacturers and researchers should carefully monitor the emerging variants and tweak their vaccines accordingly, addressing immune escaping mutations. Furthermore, a local genomic knowledge-driven vaccination policy could significantly improve the fight against COVID-19. 


\section{Conclusions and Future Directions}

We have found that vaccines developed using mRNA technology show overall better efficacy than the other strategies. However, in general, conventional inactivated vaccines show less frequent side effects, but interestingly, all vaccines exhibit a similar level of humoral immunity. The vaccine manufacturers should be careful about escape mutation, reinfection, single-dose efficacy, and minimizing unusual events while keeping the effectiveness stable or enhanced. Researchers collaborating with manufacturers should undertake studies assessing vaccine efficacy when vaccines of the same technology from different manufacturers are administered in successive doses. Consequently, they should check whether they can complement each other. Vaccine manufacturers should also systematically modify vaccines with escape mutations. Moreover, trials should also be performed with mixing or subsequent administration of vaccines of different technologies to check whether these can give a broad range of cross-protection against current emerging variants. Besides, the vaccine trials should continually be enrolled in other regions, ages, ethnicities, and health conditions. Proper funding, rigorous research, and thorough analyses are required to overcome this situation in no time.

\section{Limitation of the Study}

Due to the specific search strategy restriction for this systematic review, we could not include any study published after 1 September 2021. In addition, since we searched only online databases (i.e., PubMed, ScienceDirect, and Google Scholar) for original published articles, we could not consider any data or reports available on random online websites other than two reports from the Google Scholar database discussing the efficacy of BBIBPCorV (Table 2) [270,271].

Table 2. The major characteristics of the reported COVID-19 vaccines in the trial phase.

\begin{tabular}{|c|c|c|c|c|c|c|c|c|c|}
\hline Vaccine Type & Name & Manufacturer & Trials & Trial Model & Target & Efficacy & Advantages & Side Effects & Reference \\
\hline \multirow{4}{*}{ 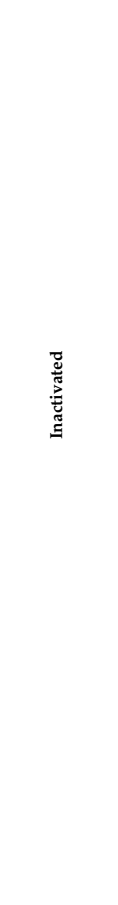 } & $\begin{array}{l}\text { BBIBP-CorV; } \\
\text { Strain: HB02 }\end{array}$ & Sinopharm & $\begin{array}{c}\text { Randomized, } \\
\text { double-blind, } \\
\text { placebo } \\
\text { controlled, phase } \\
1 / 2 \text { trial; } 2 \mu \mathrm{g}, 4 \\
\mu \mathrm{g} \text { and } 8 \mu \mathrm{g} \text { dose } \\
\text { of vaccine }\end{array}$ & $\begin{array}{c}\text { Human }(n=192 ; \\
\text { phase 1) }(n=448 \\
\text { phase 2) }\end{array}$ & Whole virus & $79-86 \%^{\mathrm{a}}$ & $\begin{array}{l}\text { Safe and well } \\
\text { controlled; the } \\
\text { humoral response } \\
\text { was induced }\end{array}$ & $\begin{array}{c}\text { Fever, pain, } \\
\text { fatigue, nausea } \\
\text { (Phase 1: } 35.5 \% \\
\text { for age } 18-59 \\
\text { years; } 27 \% \text { for } 60+ \\
\text { years. Phase } 2: \\
23 \% \text { for age } 18-59 \\
\text { years) }\end{array}$ & [120] \\
\hline & $\begin{array}{c}\text { CoronaVac; Strain: } \\
\text { CN2 }\end{array}$ & $\begin{array}{c}\text { Sinovac life } \\
\text { sciences Co., Ltd. }\end{array}$ & $\begin{array}{l}\text { Randomized, } \\
\text { double-blind, } \\
\text { placebo } \\
\text { controlled, phase } \\
1 \text { and } 2 \text { trial; } ; \mu \mathrm{g} \\
\text { and } 6 \mu \mathrm{g} \text { dose of } \\
\text { vaccine; Phase } 3 \\
\text { trial in Turkey }\end{array}$ & $\begin{array}{c}\text { Human; age: } \\
\text { 18-59 years }(n= \\
\text { 143; phase } 1),(n= \\
\text { 600; phase 2), Age: } \\
60 \text { and older }(n= \\
72 \text {; phase } 1),(n= \\
\text { 350; phase 2); } \\
\text { (age: } 18-59 \text { years; } \\
n=10,281 \text {; phase } \\
\text { 3) }\end{array}$ & Whole virus & 83.5\% (Phase 3) & $\begin{array}{l}\text { The lower } \\
\text { incident rate of } \\
\text { side effects; } \\
\text { Seroconversion } \\
\text { rate over } 90 \% \text {; } \\
\text { safe to administer } \\
\text { even in older } \\
\text { people }\end{array}$ & $\begin{array}{c}\text { Pain at injection } \\
\text { site, fever, fatigue } \\
\text { (phase 1: } 21 \% \text {; } \\
\text { Phase 2: } 26 \% \text { for } \\
\text { 18-59 years) } \\
\text { (phase 1: } 20 \% \text { for } \\
60 \text { years and } \\
\text { older) (phase 3: } \\
9.35 \% \text { ) }\end{array}$ & [122-124] \\
\hline & $\begin{array}{l}\text { BBV152; Strain: } \\
\text { NIV-2020-770 }\end{array}$ & Bharat Biotech & $\begin{array}{c}\text { Phase } 2, \\
\text { double-blind, } \\
\text { randomized } \\
\text { controlled trial, } \\
3 \mu \mathrm{g} \text { and } 6 \mu \mathrm{g} \\
\text { dose of vaccine; } \\
\text { Phase } 3, \\
\text { double-blind, } \\
\text { randomized, } \\
\text { controlled trial }\end{array}$ & $\begin{array}{c}\text { Human }(n=380 \\
\text { phase } 2)(\text { age } \\
18-98 \text { years; } n= \\
\text { 25,798; phase } 3)\end{array}$ & Whole virus & $\begin{array}{c}63.6 \%, 77.8 \% \text {, and } \\
93.4 \% \text { against } \\
\text { asymptomatic, } \\
\text { symptomatic and } \\
\text { severe COVID-19 } \\
\text { cases }\end{array}$ & $\begin{array}{c}\text { The } \\
\text { vaccine-induced } \\
\text { both cellular and } \\
\text { humoral } \\
\text { immunity along } \\
\text { with a long-lived } \\
\text { memory } \\
\text { response. }\end{array}$ & $\begin{array}{l}\text { Pain at the } \\
\text { injection site, } \\
\text { fever, fatigue, } \\
\text { headache, } \\
\text { malaise, body } \\
\text { ache, itching, } \\
\text { weakness, redness } \\
\text { at the injection } \\
\text { site (Phase 2: } \\
1.69 \%)(\text { Phase } 3: \\
12.4 \%)\end{array}$ & {$[92,128]$} \\
\hline & $\begin{array}{l}\text { Inactivated whole } \\
\text { virus COVID-19 } \\
\text { vaccine; strain: } \\
\text { WIV04 }\end{array}$ & Sinopharm & $\begin{array}{c}\text { Randomized, } \\
\text { double-blind, } \\
\text { placebo- } \\
\text { controlled, phase } \\
1 \text { and } 2 \text { trial; } \\
\text { Low }(2.5 \mu \mathrm{g}), \\
\text { medium }(5 \mu \mathrm{g}) \\
\text { and high }(10 \mu \mathrm{g}) \\
\text { for phase } 1 \text { trial } \\
\text { and } 5 \mu \mathrm{g} \text { dose of } \\
\text { vaccine for phase } \\
2 \text { trial }\end{array}$ & $\begin{array}{c}\text { Human } \\
(n=96 ; \text { phase } 1), \\
(n=224 ; \text { phase } 2) \\
\text { ongoing study }\end{array}$ & Whole virus & NR & $\begin{array}{l}\text { Immunogenic } \\
\text { with a low } \\
\text { occurrence of side } \\
\text { effects }\end{array}$ & $\begin{array}{c}\text { Pain in the } \\
\text { injection site, } \\
\text { fever, fatigue, } \\
\text { nausea and } \\
\text { vomiting (phase 1: } \\
16.7 \% \text {; Phase 2: } \\
12.5 \% \text { ) }\end{array}$ & {$[127]$} \\
\hline
\end{tabular}


Table 2. Cont.

\begin{tabular}{|c|c|c|c|c|c|c|c|c|c|}
\hline Vaccine Type & Name & Manufacturer & Trials & Trial Model & Target & Efficacy & Advantages & Side Effects & Reference \\
\hline \multirow{3}{*}{$\underset{\Xi}{\mathbb{z}}$} & mRNA-1273 & Moderna & $\begin{array}{c}\text { Phase } 1 \text { (dose } \\
\text { escalation, } \\
\text { open-label trial, } \\
25 \mu \mathrm{g}, 100 \mu \mathrm{g} \\
\text { and } 250 \mu \mathrm{g} \text { dose } \\
\text { of vaccine) Phase } \\
\text { 2,3 (randomized, } \\
\text { observer-blind, } \\
\text { placebo- } \\
\text { controlled trial) } \\
\text { phase } 2: 50 \mathrm{or} \\
100 \mu \mathrm{g} \text { dose of } \\
\text { vaccine } \\
\text { Phase } 3: 100 \mu \mathrm{g} \\
\text { dose of vaccine }\end{array}$ & $\begin{array}{c}\text { Human }(n=45 \\
\text { Phase 1), }(n=600 ; \\
\text { Phase 2), }(n= \\
\text { 30,420; Phase } 3)\end{array}$ & $\begin{array}{c}\text { Spike } \\
\text { glycoprotein } \\
\text { (S-2P antigen) }\end{array}$ & $94.1 \%$ & $\begin{array}{l}\text { Immunogenicity } \\
\text { is fast and } \\
\text { powerful; } \\
\text { antigen-specific } \\
\text { T-follicular helper } \\
\text { cells are induced } \\
\text { by prolonged } \\
\text { protein } \\
\text { expression, and } \\
\text { thus germinal } \\
\text { center B cells are } \\
\text { activated. }\end{array}$ & $\begin{array}{c}\text { Fatigue, chills, } \\
\text { fever, myalgia, } \\
\text { and discomfort at } \\
\text { the injection site } \\
\text { were the cited } \\
\text { adverse events; } \\
\text { after the second } \\
\text { dose, systemic } \\
\text { adverse events } \\
\text { were more } \\
\text { frequent. (Phase 1: } \\
67 \% \text { after 1st dose } \\
\text { and } 100 \% \text { after } \\
2 \text { nd dose; Phase 2: } \\
88 \% \text { in younger } \\
\text { and } 81 \% \text { in older; } \\
\text { phase } 3: 54.9 \% \\
\text { after 1st dose and } \\
79.4 \% \text { after } 2 \text { nd } \\
\text { dose) }\end{array}$ & [158-160] \\
\hline & BNT162b1 & $\begin{array}{l}\text { BioNTech and } \\
\text { Pfizer }\end{array}$ & $\begin{array}{l}\text { Phase 1, Phase } \\
\text { 1/2 (placebo- } \\
\text { controlled, } \\
\text { observer-blinded, } \\
\text { dose-escalation } \\
\text { trial) Phase } 1: 10 \\
\mu \mathrm{g}, 20 \mu \mathrm{g}, 30 \mu \mathrm{g}, \\
\text { and } 100 \mu \mathrm{g} \text { dose } \\
\text { of vaccine (In } \\
\mathrm{U} . \mathrm{S} \text {.) Phase I/II: } \\
10 \mu \mathrm{g}, 30 \mu \mathrm{g} \text { or } \\
100 \mu \mathrm{g} \text { dose of } \\
\text { vaccine Phase } 1 \\
\text { (randomized, } \\
\text { placebo- } \\
\text { controlled, } \\
\text { double-blind } \\
\text { trial): } 10 \mu \mathrm{g} \text { or } 30 \\
\mu \mathrm{g} \text { dose of } \\
\text { vaccine (In } \\
\text { Chinese } \\
\text { participants) }\end{array}$ & $\begin{array}{c}\text { Human ( } n=195 ; \\
\text { Phase } 1 \text { in U.S.), } \\
(n=45 ; \text { Phase } \\
\text { I/II), }(n=144 ; \\
\text { Phase } 1 \text { in } \\
\text { Chinese } \\
\text { participants })\end{array}$ & $\begin{array}{l}\text { RBD of the spike } \\
\text { protein }\end{array}$ & NR & $\begin{array}{c}\text { Immune- } \\
\text { stimulatory; can } \\
\text { be delivered into } \\
\text { cells more } \\
\text { effectively; elicit } \\
\text { both humoral and } \\
\text { cell-mediated } \\
\text { antiviral } \\
\text { mechanisms }\end{array}$ & $\begin{array}{l}\text { Pain at the } \\
\text { injection site, } \\
\text { fatigue, headache, } \\
\text { chills, muscle } \\
\text { pain, joint pain; in } \\
\text { older adults, } \\
\text { systemic } \\
\text { reactogenicity } \\
\text { profile is severe } \\
\text { (Phase } 1 / 2: \\
54.2 \%) \text {; (Phase } 1 \\
\text { study of Chinese } \\
\text { participants: } 88 \% \\
(10 \mu \mathrm{g}) \text { and } 100 \% \\
(30 \mu \mathrm{\mu g}) \text { in } \\
\text { younger } \\
\text { participants; } 83 \% \\
(10 \mu \mathrm{g}) \text { and } 92 \% \\
(30 \mu \mathrm{g}) \text { in older } \\
\text { participants }\end{array}$ & {$[130,161,163]$} \\
\hline & BNT162b2 & $\begin{array}{l}\text { BioNTech and } \\
\text { Pfizer }\end{array}$ & $\begin{array}{l}\text { Phase } 1 \text { (placebo- } \\
\text { controlled, } \\
\text { observer-blinded, } \\
\text { dose-escalation } \\
\text { trial, } 10 \mu \mathrm{\mu g}, 20 \\
\mu \mathrm{g}, 30 \mu \mathrm{\mu g} \text {, } \\
100 \mu \mathrm{g} \text { dose of } \\
\text { vaccine); } \\
\text { Phase } 2 / 3 \\
\text { (ongoing } \\
\text { multinational, } \\
\text { placebo- } \\
\text { controlled, } \\
\text { observer-blinded, } \\
\text { pivotal efficacy } \\
\text { the trial, } 30 \mu \mathrm{g} \\
\text { dose of vaccine); } \\
\text { Phase } 3 \text { (ongoing } \\
\text { multinational, } \\
\text { placebo- } \\
\text { controlled, } \\
\text { observer-blinded } \\
\text { trial, } 30 \mu \mathrm{g} \text { dose } \\
\text { of vaccine) }\end{array}$ & $\begin{array}{c}\text { Human }(n=195 ; \\
\text { Phase 1), }(n= \\
\text { 43,548; Phase 2/3) } \\
(n=2260 ; \text { Phase } 3)\end{array}$ & Full-length spike & $\begin{array}{c}95 \% \text { (16 years of } \\
\text { age or older) } \\
100 \% \text { ( } 12 \text { to } 15 \\
\text { years of age) }\end{array}$ & $\begin{array}{l}\text { In older adults, } \\
\text { systemic } \\
\text { reactogenicity } \\
\text { profile is mild } \\
\text { mainly; } \\
\text { reactogenicity } \\
\text { and } \\
\text { immunogenicity } \\
\text { profile are in a } \\
\text { good balance; } \\
\text { Highly effective } \\
\text { against COVID-19 } \\
\text { in adolescents }\end{array}$ & $\begin{array}{c}\text { Pain at the } \\
\text { injection site, } \\
\text { fatigue, chills, } \\
\text { muscle pain, joint } \\
\text { pain, headache, } \\
\text { fever, redness or } \\
\text { swelling (Phase 1: } \\
17 \% \text { in } 65-85 \\
\text { years. } 25 \% \text { in } \\
18-55 \text { years; } \\
\text { Phase } 2 / 3: 42.33 \% \\
\text { in younger and } \\
33.67 \% \text { in older; } \\
\text { Phase 3: } 68.5 \% \text { ) }\end{array}$ & {$[94,161,164]$} \\
\hline \multirow[b]{2}{*}{ 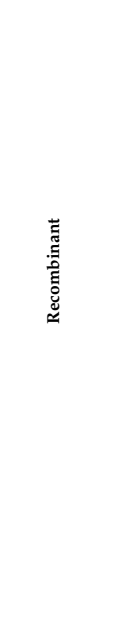 } & FINLAY-FR-1A & $\begin{array}{l}\text { Finlay Vaccine } \\
\text { Institute in } \\
\text { Havana, Cuba }\end{array}$ & $\begin{array}{l}\text { Phase } 1 \text { (open, } \\
\text { adaptive, and } \\
\text { monocentric } \\
\text { clinical trial, } \\
50 \mu \mathrm{g} \text { dose of } \\
\text { vaccine) Ongoing }\end{array}$ & Human $(n=30)$ & RBD & NR & $\begin{array}{l}\text { Excellent safety } \\
\text { profile and } \\
\text { single-dose } \\
\text { increases } \\
\text { neutralization } \\
\text { responses in } \\
\text { COVID-19 } \\
\text { convalescents }\end{array}$ & $\begin{array}{l}\text { Pain at the } \\
\text { injection site, } \\
\text { warmth, redness, } \\
\text { swelling, malaise, } \\
\text { rash, fever, high } \\
\text { blood pressure. } \\
\text { (Phase 1: 20\%) }\end{array}$ & [194] \\
\hline & $\begin{array}{l}\text { Ad5 vectored } \\
\text { COVID-19 } \\
\text { vaccine }\end{array}$ & $\begin{array}{l}\text { Beijing Institute of } \\
\text { Biotechnology } \\
\text { and CanSino } \\
\text { Biologics }\end{array}$ & $\begin{array}{c}\text { Phase } 1 \text { (dose } \\
\text { escalation, } \\
\text { single-center } \\
\text { open-label, } \\
\text { non-randomized } \\
\text { trial, dose: } 5 \times \\
10^{10}, 1 \times 10^{11} \\
\text { and } 1.5 \times 10^{11} \\
\text { viral particles); } \\
\text { Phase } 2 \\
\text { (randomized, } \\
\text { double-blind, } \\
\text { placebo- } \\
\text { controlled trial, } \\
\text { dose: } 1 \times 10^{11} \\
\text { viral particles per } \\
\text { mL or } 5 \times 1010 \\
\text { viral particles per } \\
\mathrm{mL} \text { ) }\end{array}$ & $\begin{array}{l}\text { Human }(n=108 \\
\text { Phase1) }(n=508 \\
\text { Phase 2) }\end{array}$ & $\begin{array}{c}\text { Spike } \\
\text { glycoprotein }\end{array}$ & NR & $\begin{array}{l}\text { Well tolerable and } \\
\text { immunogenic; } \\
\text { Safe; significant } \\
\text { immune } \\
\text { responses are } \\
\text { induced after a } \\
\text { single } \\
\text { vaccination. }\end{array}$ & $\begin{array}{c}\text { Systematic } \\
\text { adverse reactions: } \\
\text { fever, fatigue, } \\
\text { headache, and } \\
\text { muscle pain } \\
\text { (Phase 1: } 84.5 \% \text {; } \\
\text { phase 2: } 73 \% \\
\text { solicited adverse } \\
\text { event and 5\% } \\
\text { severe adverse } \\
\text { reaction) }\end{array}$ & {$[178,179]$} \\
\hline
\end{tabular}


Table 2. Cont.

\begin{tabular}{|c|c|c|c|c|c|c|c|c|c|}
\hline Vaccine Type & Name & Manufacturer & Trials & Trial Model & Target & Efficacy & Advantages & Side Effects & Reference \\
\hline & $\begin{array}{l}\text { Aerosolised } \\
\text { Ad5-nCoV }\end{array}$ & $\begin{array}{c}\text { Institute of } \\
\text { Biotechnology, } \\
\text { Academy of } \\
\text { Military Medical } \\
\text { Sciences, PLA of } \\
\text { China }\end{array}$ & $\begin{array}{c}\text { Phase } 1 \\
\text { (randomized, } \\
\text { single-center, } \\
\text { open-label, trial, } \\
\text { dose: } 2 \times 10^{10}, 1 \\
\times 10^{10}, 5 \times 10^{10} \\
10 \times 10^{10} \text { viral } \\
\text { particles) }\end{array}$ & Human $(n=130)$ & $\begin{array}{c}\text { Spike } \\
\text { glycoprotein }\end{array}$ & NR & $\begin{array}{l}\text { Well tolerable, } \\
\text { Painless, Simple, } \\
\text { Strong IgG and } \\
\text { neutralizing } \\
\text { antibody } \\
\text { responses. }\end{array}$ & $\begin{array}{l}\text { Fever, fatigue, } \\
\text { headache }(25 \% \\
\text { adverse events in } \\
\text { aerosol vaccine } \\
\text { group) }\end{array}$ & [180] \\
\hline & $\begin{array}{c}\text { ChAdOx1 } \\
\text { nCoV-19 OR } \\
\text { AZD1222 }\end{array}$ & AstraZeneca & $\begin{array}{c}\text { Phase } 1 / 2 \\
\text { single-blind, } \\
\text { randomized } \\
\text { controlled trial } \\
\text { receive } \\
\text { ChAdOxinCoV- } \\
19 \text { or MenACWY } \\
\text { at a dose of } 5 \times \\
10^{10} \text { viral } \\
\text { particles; Phase } \\
2 / 3 \text { trial; } \mathrm{LD} \\
\text { cohort -receive; } \\
2.2 \times 10^{10} \text { virus } \\
\text { particles; SD } \\
\text { cohort receive } \\
3 \cdot 5-6 \cdot 5 \times 10^{10} \\
\text { virus particles of } \\
\text { ChAdOx1 } \\
\text { nCoV-19) }\end{array}$ & $\begin{array}{c}\text { Healthy human } \\
\text { model (Phase } 1 / 2 \\
n=1077 ; \text { Phase } \\
2 / 3, n=560\end{array}$ & $\begin{array}{l}\text { Whole Spike } \\
\text { protein }\end{array}$ & $\begin{array}{c}\text { Overall } \\
\text { efficacy- } 70.4 \%\end{array}$ & $\begin{array}{l}\text { Single-dose of } \\
\text { ChAdOx1 } \\
\text { nCoV-19 elicits } \\
\text { increased } \\
\text { spike-specific } \\
\text { antibody; remain } \\
\text { asymptomatic to } \\
\text { develop a robust } \\
\text { memory T-cell } \\
\text { response; safe, } \\
\text { tolerated, and } \\
\text { immunogenic; } \\
\text { elicit both } \\
\text { humoral and } \\
\text { cellular responses; } \\
\text { no adverse events } \\
\text { even after the } \\
\text { booster dose }\end{array}$ & $\begin{array}{c}\text { Local and } \\
\text { systemic reactions } \\
\text { including; } \\
\text { injection site pain, } \\
\text { feverish, chills, } \\
\text { muscle ache, } \\
\text { headache, and } \\
\text { malaise. Phase } \\
1 / 2 \\
\text { trial- } 63.259 \% ; \\
\text { Phase } 2 / 3 \text { trial- } \\
75 \%\end{array}$ & [93,181-183] \\
\hline & $\begin{array}{l}\text { Sputnik V, (Gam- } \\
\text { COVID-Vac) }\end{array}$ & $\begin{array}{l}\text { Developed by The } \\
\text { Gamaleya } \\
\text { National Center } \\
\text { of Epidemiology } \\
\text { and Microbiology }\end{array}$ & $\begin{array}{l}\text { Phase } 1 / 2 \text { studies } \\
\text { at two hospitals } \\
\text { in Russian two } \\
\text { studies ( } 38 \text { in each } \\
\text { study). In each } \\
\text { study, nine } \\
\text { volunteers } \\
\text { received rAd26-S } \\
\text { in phase 1, nine } \\
\text { received rAd5-S } \\
\text { in phase 1, and 20 } \\
\text { received rAd26-S } \\
\text { and rAd5-S in } \\
\text { phase 2. Phase } 3 \\
\text { trial held at 25 } \\
\text { hospitals }\end{array}$ & $\begin{array}{c}\text { Human model } \\
\text { (phase } 1 / 2, n=76 \\
\text { Phase } 3, n= \\
21,977 \\
\text { (Vaccine group } \\
n-16,501 \text {; Placebo } \\
\text { group } n-5476 \text { ) }\end{array}$ & $\begin{array}{l}\text { Spike protein } \\
\text { Vector }\end{array}$ & $\begin{array}{c}91.6 \% \text { after } 2 \\
\text { doses, } 79.4 \% \text { after } \\
1 \text { dose }\end{array}$ & $\begin{array}{l}\text { Safe; well } \\
\text { tolerated; induced } \\
\text { strong humoral } \\
\text { and cellular } \\
\text { immune } \\
\text { responses in 100\% } \\
\text { of healthy } \\
\text { participants; no } \\
\text { serious adverse } \\
\text { events }\end{array}$ & $\begin{array}{l}\text { The most } \\
\text { common systemic } \\
\text { and local } \\
\text { reactions were } \\
\text { pain at the } \\
\text { injection site, } \\
\text { hyperthermia, } \\
\text { headache, } \\
\text { asthenia, and } \\
\text { muscle and joint } \\
\text { pain; Phase } 1 / 2 \\
\text { trial- } 40.4 \% \\
\text { Phase } 3 \text { trial, } 47 \%\end{array}$ & {$[187,193]$} \\
\hline & Ad26.COV2.S & $\begin{array}{l}\text { Manufactured by } \\
\text { Janssen } \\
\text { Pharmaceuticals } \\
\text { companies } \\
\text { acquired by } \\
\text { Johnson \& } \\
\text { Johnson }\end{array}$ & $\begin{array}{l}\text { Multicenter, } \\
\text { placebo- } \\
\text { controlled, Phase } \\
\text { 1-2a trial to } \\
\text { evaluate the } \\
\text { safety and } \\
\text { immunogenicity } \\
\text { profiles of } \\
\text { Ad26.COV2.S; } \\
\text { Randomized, } \\
\text { double-blind, } \\
\text { placebo- } \\
\text { controlled, Phase } \\
3 \text { trial to } \\
\text { determine the } \\
\text { effectiveness of } \\
\text { the vaccine. }\end{array}$ & $\begin{array}{c}\text { Human model } \\
\text { (Phase } 1 / 2 \mathrm{a} \text { trial, } \\
N, 805 \\
\text { participants Phase } \\
3 \text { trial, } n, 43,783 \text { ) }\end{array}$ & $\begin{array}{l}\text { A recombinant, } \\
\text { replication- } \\
\text { deficient } \\
\text { adenovirus } \\
\text { serotype 26 } \\
\text { (Ad26) vector } \\
\text { encoding a } \\
\text { stabilized } \\
\text { SARS-CoV-2 } \\
\text { spike (S) protein }\end{array}$ & $66 \%$ & $\begin{array}{l}\text { Neutralizing } \\
\text { antibody } \\
\text { response } 100 \% \text { by } \\
\text { day } 57 ; \\
\text { Spike-binding } \\
\text { antibody and } \\
\text { neutralizing } \\
\text { antibody } \\
\text { response were } \\
\text { similar; CD4+ } \\
\text { T-cell response- } \\
76-83 \%(18-55 \\
\text { years age group) } \\
60-66 \% \text { (65 years } \\
\text { or older) }\end{array}$ & $\begin{array}{l}\text { Cohort } 1(18-55 \\
\text { years group): } \\
\text { local adverse } \\
\text { event } 71 \% \\
\text { and systemic } \\
\text { adverse } \\
\text { event-74.5\%; } \\
\text { Cohort } 3(65 \text { years } \\
\text { or older): local } \\
\text { adverse event } \\
41.5 \% \text { and } \\
\text { systemic adverse } \\
\text { event } 50.5 \%\end{array}$ & {$[196,198]$} \\
\hline 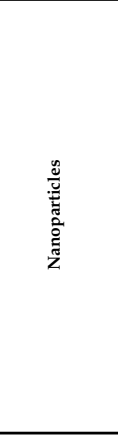 & NVX-CoV2373 & Novavax & $\begin{array}{l}\text { A randomized, } \\
\text { placebo- } \\
\text { controlled, Phase } \\
1-2 \text { trial to } \\
\text { evaluate the } \\
\text { safety and } \\
\text { immunogenicity } \\
\text { of the } \\
\text { rSARS-CoV-2 } \\
\text { vaccine (in } 5 \mu \mathrm{\mu g} \\
\text { and } 25 \mu \mathrm{g} \text { doses, } \\
\text { with or without } \\
\text { Matrix-M1 } \\
\text { adjuvant Phase 3, } \\
\text { randomized, } \\
\text { observer-blinded, } \\
\text { placebo- } \\
\text { controlled trial } \\
\text { conducted at } 33 \\
\text { sites in the UK }\end{array}$ & $\begin{array}{c}\text { Human model, } \\
\text { (Phase 1/2a, } \\
n-131 ; \text { Phase 3, } \\
n-15,187 \text { ) }\end{array}$ & $\begin{array}{c}\text { Nanoparticle } \\
\text { vaccine composed } \\
\text { of trimeric } \\
\text { full-length } \\
\text { SARS-CoV-2 } \\
\text { spike } \\
\text { glycoproteins and } \\
\text { Matrix-M1, a } \\
\text { saponin-based } \\
\text { adjuvant Vector } \\
\text { type- Baculovirus }\end{array}$ & $89.7 \%$ & $\begin{array}{c}\text { Proper } \\
\text { vaccine-induced } \\
\text { immunogenicity; } \\
\text { Stimulates both } \\
\text { high neutralizing } \\
\text { antibody } \\
\text { responses and T } \\
\text { cells; storable at } 4 \\
\text { degrees C for a } \\
\text { long time and } \\
\text { easily } \\
\text { transportable; } \\
\text { capable of } \\
\text { restraining new } \\
\text { variants in UK } \\
\text { and South Africa }\end{array}$ & $\begin{array}{l}\text { Phase } 1 / 2 \\
\text { trial-localized } \\
\text { symptoms: } \\
\text { (86.4\%) erythema } \\
\text { or redness, } \\
\text { induration or } \\
\text { swelling, pain, } \\
\text { tenderness; } \\
\text { systemic } \\
\text { symptoms: } \\
\text { (79.4\%) arthralgia, } \\
\text { fatigue, fever, } \\
\text { headache, } \\
\text { myalgia, nausea, } \\
\text { malaise; Phase } 3 \\
\text { trial--Systemic } \\
\text { adverse event; } \\
\text { after 1st dose } \\
\text { 21.76\%. After 2nd } \\
\text { dose- } 40.2 \%\end{array}$ & {$[208,209]$} \\
\hline
\end{tabular}

${ }^{\mathrm{a}}[270,271], \mathrm{NR}=$ Not reported.

\section{Article Highlights}

(1) This review was selected through an appropriate systematic search strategy.

(2) This review discusses different types of vaccines strategies (i.e., inactivated, mRNA based, recombinant, and nanoparticle-based vaccines) developed so far for SARS CoV-2.

(3) Vaccines from a variety of manufacturers and countries have been discussed and categorized separately, based on their types.

(4) The overall efficacy and safety of each of the candidates based on trial has been discussed.

(5) The limitations of the clinical trials, issues, and other perspectives have been discussed. 
Supplementary Materials: The following are available online at https://www.mdpi.com/article/10 $.3390 /$ vaccines 9121387 / s1, Table S1: Search strategy.

Author Contributions: Conceptualization, B.G., M.A.H., M.R.J., M.H. and N.A. (Nihad Adnan); methodology, S.S.K., M.I.J., B.A.M., T.A.T., M.A.H., M.R.J., M.H. and N.A. (Nihad Adnan); vali-dation, B.G., M.A.H., M.U.K., M.R.J., M.H. and N.A. (Nihad Adnan); formal analysis, S.S.K., M.I.J., B.A.M., T.A.T., M.A.H., M.R.J., M.H. and N.A. (Nihad Adnan); investigation, S.S.K., M.I.J., B.A.M., T.A.T., M.A.H., M.R.J., M.H. and N.A. (Nihad Adnan); data curation, S.S.K., M.A.H., M.R.J., M.H. and N.A. (Nihad Adnan); writing—original draft preparation, S.S.K., M.I.J., B.A.M., T.A.T., M.A.H., S.S., M.R.J., M.H. and N.A. (Nihad Adnan); writing-review and editing, B.G., M.U.K., J.C., A.A.T., N.A. (Nafisa Azmuda), M.A.H., M.R.J., M.H. and N.A. (Nihad Adnan); visualization, B.G., M.U.K., M.A.H., M.R.J., M.H. and N.A. (Nihad Adnan); supervision, M.H. and N.A. (Nihad Adnan). All authors have read and agreed to the published version of the manuscript.

Funding: This research received no external funding.

Data Availability Statement: Not applicable.

Conflicts of Interest: The authors declare no conflict of interest.

\section{References}

1. Andersen, K.G.; Rambaut, A.; Lipkin, W.I.; Homes, E.C.; Garry, R.F. The proximal origin of SARS-CoV-2. Nat. Med. 2020, 26, 450-452. [CrossRef]

2. Zhang, Y.-Z.; Holmes, E.C. A genomic perspective on the origin and emergence of SARS-CoV-2. Cell 2020, 181, 223-227. [CrossRef]

3. Stadler, K.; Masignani, V.; Eickmann, M.; Becker, S.; Abrignani, S.; Klenk, H.D.; Rappuoli, R. SARS-Beginning to understand a new virus. Nat. Rev. Microbiol. 2003, 1, 209-218. [CrossRef] [PubMed]

4. Woo, P.C.; Huang, Y.; Lau, S.K.; Yuen, K.Y. Coronavirus genomics and bioinformatics analysis. Viruses 2010, 2, 1804-1820. [CrossRef]

5. Woo, P.C.; Lau, S.K.; Lam, C.S.; Lau, C.C.; Tsang, A.K.; Lau, J.H.; Bai, R.; Teng, J.L.; Tsang, C.C.; Wang, M.; et al. Discovery of seven novel Mammalian and avian coronaviruses in the genus deltacoronavirus supports bat coronaviruses as the gene source of alphacoronavirus and betacoronavirus and avian coronaviruses as the gene source of gammacoronavirus and deltacoronavirus. $J$. Virol. 2012, 86, 3995-4008. [PubMed]

6. Tyrrell, D.; Bynoe, M. Cultivation of viruses from a high proportion of patients with colds. Lancet 1966, 1, 76-77. [CrossRef]

7. Hamre, D.; Procknow, J.J. A new virus isolated from the human respiratory tract. Proc. Soc. Exp. Biol. Med. 1966, 121, 190-193. [CrossRef] [PubMed]

8. Pensaert, M.; Debouck, P.; Reynolds, D. An immunoelectron microscopic and immunofluorescent study on the antigenic relationship between the coronavirus-like agent, CV 777, and several coronaviruses. Arch. Virol. 1981, 68, 45-52. [CrossRef] [PubMed]

9. Bradburne, A. Antigenic relationships amongst coronaviruses. Arch. Gesamte Virusforsch. 1970, 31, 352-364. [CrossRef] [PubMed]

10. McIntosh, K.; Kapikian, A.Z.; Hardison, K.A.; Hatrley, K.A.; Chanock, R.M. Antigenic relationships among the coronaviruses of man and between human and animal coronaviruses. J. Immunol. 1969, 102, 1109-1118.

11. Van Der Hoek, L.; Pyrc, K.; Jebbink, M.F.; Vermeulen-Oost, W.; Berkhout, R.J.; Wolthers, K.C.; Dillen, P.M.; Kaandrop, J.; Spaargaren, J.; Berkhout, B. Identification of a new human coronavirus. Nat. Med. 2004, 10, 368-373. [CrossRef]

12. Koetz, A.; Nilsson, P.; Lindén, M.; Hoek, L.V.; Ripa, T. Detection of human coronavirus NL63, human metapneumovirus and respiratory syncytial virus in children with respiratory tract infections in south-west Sweden. Clin. Microbiol. Infect. 2006, 12, 1089-1096. [CrossRef] [PubMed]

13. Lau, S.K.; Woo, P.C.; Yip, C.C.; Tse, H.; Tsoi, H.; Cheng, V.C.; Lee, P.; Tang, B.S.; Cheung, C.H.; Lee, R. A Coronavirus HKU1 and other coronavirus infections in Hong Kong. J. Clin. Microbiol. 2006, 44, 2063-2071. [CrossRef] [PubMed]

14. Esper, F.; Weibel, C.; Ferguson, D.; Landry, M.L.; Kahn, J.S. Coronavirus HKU1 infection in the United States. Emerg. Infect. Dis. 2006, 12, 775. [CrossRef] [PubMed]

15. Bosis, S.; Esposito, S.; Niesters, H.G.; Tremolati, E.; Pas, S.; Principi, N.; Osterhaus, A.D. Coronavirus HKU1 in an Italian pre-term infant with bronchiolitis. J. Clin. Virol. 2007, 38, 251. [CrossRef] [PubMed]

16. Kupfer, B.; Simon, A.; Jonassen, C.; Viazov, S.; Ditt, V.; Tillman, R.; Muller, A.; Matz, B.; Schildgen, O. Two cases of severe obstructive pneumonia associated with an HKU1-like coronavirus. Eur. J. Med. Res. 2007, 12, 134. [PubMed]

17. Zhang, J.; Guy, J.S.; Snijder, E.J.; Denniston, D.A.; Timoney, P.J.; Balasuriya, U.B. Genomic characterization of equine coronavirus. Virology 2007, 369, 92-104. [CrossRef]

18. Mihindukulasuriya, K.A.; Wu, G.; St. Leger, J.; Nordhausen, R.W.; Wang, D. Identification of a novel coronavirus from a beluga whale by using a panviral microarray. J. Virol. 2008, 82, 5084-5088. [CrossRef]

19. Lau, S.K.; Woo, P.C.; Li, K.S.; Huang, Y.; Wang, M.; Lam, C.S.; Xu, H.; Guo, R.; Chan, K.; Zheng, B.; et al. Complete genome sequence of bat coronavirus HKU2 from Chinese horseshoe bats revealed a much smaller spike gene with a different evolutionary lineage from the rest of the genome. Virology 2007, 367, 428-439. [CrossRef] 
20. Chu, D.; Peiris, J.; Chen, H.; Guan, Y.; Poon, L.L. Genomic characterizations of bat coronaviruses (1A, 1B and HKU8) and evidence for co-infections in Miniopterus bats. J. Gen. Virol. 2008, 89, 1282-1287. [CrossRef]

21. Lau, S.K.; Woo, P.C.; Li, K.S.; Tsoi, H.; Wong, B.H.; Wong, S.S.; Leung, S.; Chan, K.; Yuen, K. Severe acute respiratory syndrome coronavirus-like virus in Chinese horseshoe bats. Proc. Natl. Acad. Sci. USA 2005, 102, 14040-14045. [CrossRef] [PubMed]

22. Woo, P.C.; Lau, S.K.; Li, K.S.; Poon, R.W.; Wong, B.H.; Tsoi, H.; Yip, B.C.; Huang, Y.; Chan, K.; Yuen, K. Molecular diversity of coronaviruses in bats. Virology 2006, 351, 180-187. [CrossRef] [PubMed]

23. Woo, P.C.; Wang, M.; Lau, S.K.; Poon, R.W.; Guo, R.; Wong, B.H.; Gao, K.; Tsoi, H.; Huang, Y.; Li, K.S.; et al. Comparative analysis of twelve genomes of three novel group $2 \mathrm{c}$ and group $2 \mathrm{~d}$ coronaviruses reveals unique group and subgroup features. J. Virol. 2007, 81, 1574-1585. [CrossRef] [PubMed]

24. Li, W.; Shi, Z.; Yu, M.; Ren, W.; Smith, C.; Epstein, J.H.; Wang, H.; Crameri, G.; Hu, Z.; Zhang, H.; et al. Bats are natural reservoirs of SARS-like coronaviruses. Science 2005, 310, 676-679. [CrossRef]

25. Tang, X.; Zhang, J.; Zhang, S.; Wang, P.; Fan, X.S.; Li, L.F.; Li, G.; Dong, B.Q.; Liu, W.; Xu, K.M.; et al. Prevalence and genetic diversity of coronaviruses in bats from China. J. Virol. 2006, 80, 7481-7490. [CrossRef]

26. Van der Hoek, L. Human coronaviruses: What do they cause? Antivir. Ther. 2007, 12, 651-658.

27. Drosten, C.; Günther, S.; Preiser, W.; Werf, S.V.; Brodt, H.; Backer, S.; Rabenau, H.; Panning, M.; Kolesnikova, L.; Fouchier, R.A.; et al. Identification of a novel coronavirus in patients with severe acute respiratory syndrome. N. Engl. J. Med. 2003, 348, $1967-1976$. [CrossRef]

28. Malande, O.O.; Musyoki, A.M.; Meyer, J.C.; Godman, B.; Masika, J. Understanding the pathophysiology of COVID-19: A review of emerging concepts. EC Paediatr. 2021, 10, 22-30.

29. Adhikari, S.P.; Meng, S.; Wu, Y.-J.; Mao, Y.; Ye, R.; Wang, Q.; Sun, C.; Sylvia, S.; Rozelle, S.; Raat, H.; et al. Epidemiology, causes, clinical manifestation and diagnosis, prevention and control of coronavirus disease (COVID-19) during the early outbreak period: A scoping review. Infect. Dis. Poverty 2020, 9, 29. [CrossRef]

30. Abubakar, A.R.; Sani, I.H.; Godman, B.; Kumar, S.; Jahan, I.; Haque, M. Systematic review on the therapeutic options for COVID-19: Clinical evidence of drug efficacy and implications. Infect. Drug Resist. 2020, 13, 4673. [CrossRef]

31. Huang, C.; Wang, Y.; Li, X.; Ren, L.; Zhao, J.; Hu, Y.; Zhang, L.; Fan, G.; Xu, J.; Gu, X.; et al. Clinical features of patients infected with 2019 novel coronavirus in Wuhan, China. Lancet 2020, 395, 497-506. [CrossRef]

32. Zhu, N.; Zhang, D.; Wang, W.; Li, X.; Yang, B.; Song, J.; Zhao, X.; Huang, B.; Shi, W.; Lu, R.; et al. A novel coronavirus from patients with pneumonia in China, 2019. N. Engl. J. Med. 2020, 382, 727-733. [CrossRef] [PubMed]

33. CDC. Human Coronavirus Types CDC2020. Available online: https:/ /www.cdc.gov/coronavirus/types.html (accessed on 31 August 2021).

34. Worldometer. COVID-19 Coronavirus Pandemic. Worldometer. 2021. Available online: https://www.worldometers.info/ coronavirus / (accessed on 31 August 2021).

35. Morawska, L.; Cao, J. Airborne transmission of SARS-CoV-2: The world should face the reality. Environ. Int. 2020, 139, 105730. [CrossRef] [PubMed]

36. Klompas, M.; Baker, M.A.; Rhee, C. Airborne transmission of SARS-CoV-2: Theoretical considerations and available evidence. JAMA 2020, 324, 441-442. [CrossRef] [PubMed]

37. Anderson, E.L.; Turnham, P.; Griffin, J.R.; Clarke, C.C. Consideration of the aerosol transmission for COVID-19 and public health. Risk Anal. 2020, 40, 902-907. [CrossRef] [PubMed]

38. Prather, K.A.; Wang, C.C.; Schooley, R.T. Reducing transmission of SARS-CoV-2. Science 2020, 368, 1422-1424. [CrossRef]

39. Li, Q.; Guan, X.; Wu, P.; Wang, X.; Zhou, L.; Tong, Y.; Ren, R.; Leung, K.S.; Lau, E.H.; Wong, J.Y.; et al. Early transmission dynamics in Wuhan, China, of novel coronavirus-infected pneumonia. N. Engl. J. Med. 2020, 382, 1199-1207. [CrossRef]

40. Van Doremalen, N.; Bushmaker, T.; Morris, D.H.; Holbrook, M.G.; Gamble, A.; Williamsom, B.N.; Tamin, A.; Harcourt, J.L.; Thornburg, N.J.; Gerber, S.I.; et al. Aerosol and surface stability of SARS-CoV-2 as compared with SARS-CoV-1. N. Engl. J. Med. 2020, 382, 1564-1567. [CrossRef]

41. Rothe, C.; Schunk, M.; Sothmann, P.; Bretzel, G.; Froeschi, G.; Wallrauch, C.; Zimmer, T.; Thiel, V.; Janke, C.; Guggesmos, W.; et al. Transmission of 2019-nCoV infection from an asymptomatic contact in Germany. N. Engl. J. Med. 2020, 382, 970-971. [CrossRef]

42. Shang, J.; Wan, Y.; Luo, C.; Ye, G.; Geng, Q.; Auerbach, A.; Li, F. Cell entry mechanisms of SARS-CoV-2. Proc. Natl. Acad. Sci. USA 2020, 117, 11727-11734. [CrossRef]

43. Hamming, I.; Timens, W.; Bulthuis, M.L.C.; Lely, A.T.; Navis, G.V.; van Goor, H. Tissue distribution of ACE2 protein, the functional receptor for SARS coronavirus. A first step in understanding SARS pathogenesis. J. Pathol. A J. Pathol. Soc. Great Br. Irel. 2004, 203, 631-637. [CrossRef] [PubMed]

44. Robba, C.; Battaglini, D.; Pelosi, P.; Rocco, P.R. Multiple organ dysfunction in SARS-CoV-2: MODS-CoV-2. Expert Rev. Respir. Med. 2020, 14, 865-868. [CrossRef] [PubMed]

45. Chu, H.; Chan, J.F.-W.; Wang, Y.; Yuen, T.T.; Chai, Y.; Hou, Y.; Shuai, H.; Yang, S.; Hu, B.; Huang, X.; et al. Comparative replication and immune activation profiles of SARS-CoV-2 and SARS-CoV in human lungs: An ex vivo study with implications for the pathogenesis of COVID-19. Clin. Infect. Dis. 2020, 71, 1400-1409. [CrossRef] [PubMed]

46. Bai, Y.; Yao, L.; Wei, T. Presumed asymptomatic carrier transmission of COVID-19. JAMA 2020, 323, 1406-1407. [CrossRef]

47. Jacot, D.; Greub, G.; Jaton, K.; Opota, O. Viral load of SARS-CoV-2 across patients and compared to other respiratory viruses. Microbes Infect. 2020, 22, 617-621. [CrossRef] 
48. Feikin, D.R.; Fu, W.; Park, D.E.; Shi, Q.; Higdon, M.M.; Baggett, H.C.; Brooks, W.A.; Knoll, M.D.; Hammitt, L.L.; Howie, S.R.; et al. Is higher viral load in the upper respiratory tract associated with severe pneumonia? Findings from the PERCH study. Clin. Infect. Dis. 2017, 64 (Suppl. 3), S337-S346. [CrossRef]

49. Yang, L.; Liu, S.; Liu, J.; Zhang, Z.; Wan, X.; Huang, B.; Chen, Y.; Zhang, Y. COVID-19: Immunopathogenesis and Immunotherapeutics. Signal Transduct. Target. Ther. 2020, 5, 128. [CrossRef]

50. Henry, B.M.; Cheruiyot, I.; Vikse, J.; Mutua, V.; Kipkorir, V.; Benoit, J.; Plebani, M.; Bragazzi, N.; Lippi, G. Lymphopenia and neutrophilia at admission predicts severity and mortality in patients with COVID-19: A meta-analysis. Acta Bio-Med. Atenei Parm. 2020, 91, e2020008.

51. Tleyjeh, I.M.; Kashour, Z.; Damlaj, M.; Riaz, M.; Tlayjeh, H.; Altannir, M.; Altannir, Y.; Al-Tannir, M.; Tlayjeh, R.; Hassett, L.; et al. Efficacy and safety of tocilizumab in COVID-19 patients: A living systematic review and meta-analysis. Clin. Microbiol. Infect. 2020, 27, 215-227. [CrossRef]

52. The RECOVERY Collaborative Group. Effect of hydroxychloroquine in hospitalized patients with COVID-19. N. Engl. J. Med. 2020, 383, 2030-2040. [CrossRef]

53. Charan, J.; Kaur, R.J.; Bhardwaj, P.; Haque, M.; Sharma, P.; Misra, S.; Godman, B. Rapid review of suspected adverse drug events due to remdesivir in the WHO database; Findings and implications. Expert Rev. Clin. Pharmacol. 2021, 14, 95-103. [CrossRef]

54. WHO. WHO Discontinues Hydroxychloroquine and Lopinavir/Ritonavir Treatment Arms for COVID-19. 2020. Available online: https:/ / www.who.int/news-room/detail/04-07-2020-who-discontinues-hydroxychloroquine-and-lopinavir-ritonavirtreatment-arms-for-covid-19 (accessed on 4 July 2020).

55. Rochwerg, B.; Agarwal, A.; Siemieniuk, R.A.; Agoritsas, T.; Lamontagne, F.; Askie, L.; Lytvyn, L.; Leo, Y.; Macdonald, H.; Zeng, L. A living WHO guideline on drugs for COVID-19. BMJ 2020, 370, m3379. [CrossRef] [PubMed]

56. Horby, P.W.; Mafham, M.; Bell, J.L.; Linsell, L.; Staplin, N.; Emberson, J.; Palfreeman, A.; Raw, J.; Elmahi, E.; Prudon, B.; et al. Lopinavir-ritonavir in patients admitted to hospital with COVID-19 (RECOVERY): A randomised, controlled, open-label, platform trial. Lancet 2020, 396, 1345-1352. [CrossRef]

57. Dzieciatkowski, T.; Szarpak, L.; Filipiak, K.J.; Jaguszewski, M.; Landy, J.R.; Smereka, J. COVID-19 challenge for modern medicine. Cardiol. J. 2020, 27, 175-183. [CrossRef] [PubMed]

58. Hatmi, Z.N. A systematic review of systematic reviews on the COVID-19 pandemic. SN Compr. Clin. Med. 2021, 3, 419-436. [CrossRef]

59. Ayouni, I.; Maatoug, J.; Dhouib, W.; Zammit, N.; Fredj, S.B.; Ghammam, R.; Ghannem, H. Effective public health measures to mitigate the spread of COVID-19: A systematic review. BMC Public Health 2021, 21, 1015. [CrossRef] [PubMed]

60. Mendez-Brito, A.; El Bcheraoui, C.; Pozo-Martin, F. Systematic review of empirical studies comparing the effectiveness of non-pharmaceutical interventions against COVID-19. J. Infect. 2021, 83, 281-293. [CrossRef]

61. Kluge, H.H.P.; Wickramasinghe, K.; Rippin, H.L.; Mendes, R.; Peters, D.H.; Kontsevaya, A.; Breda, J. Prevention and control of non-communicable diseases in the COVID-19 response. Lancet 2020, 395, 1678-1680. [CrossRef]

62. Wu, T.; Jia, X.; Shi, H.; Niu, J.; Yin, X.; Xie, J.; Wang, X. Prevalence of mental health problems during the COVID-19 pandemic: A systematic review and meta-analysis. J. Affect. Disord. 2020, 281, 91-98. [CrossRef]

63. Cénat, J.M.; Blais-Rochette, C.; Kokou-Kpolou, C.K.; Noorishad, P.; Mukunzi, J.N.; Mclntee, S.; Dalexis, R.D.; Goulet, M.; Labelle, P.R. Prevalence of symptoms of depression, anxiety, insomnia, posttraumatic stress disorder, and psychological distress among populations affected by the COVID-19 pandemic: A systematic review and meta-analysis. Psychiatry Res. 2020, 295, 113599. [CrossRef]

64. Abbas, K.; Procter, S.R.; Van Zandvoort, K.; Clark, A.; Funk, S.; Mengistu, T.; Hogan, D.; Dansereau, E.; Jit, M.; Flasche, S. Routine childhood immunisation during the COVID-19 pandemic in Africa: A benefit-risk analysis of health benefits versus excess risk of SARS-CoV-2 infection. Lancet Glob. Health 2020, 8, e1264-e1272. [CrossRef]

65. Ogunleye, O.O.; Basu, D.; Mueller, D.; Sneddon, J.; Seaton, R.A.; Yinka-Ogunleye, A.F.; Wanboga, J.; Miljkovic, N.; Mwita, J.C.; Rwegerera, G.M. Response to the novel corona virus (COVID-19) pandemic across Africa: Successes, challenges, and implications for the future. Front. Pharmacol. 2020, 11, 1205. [CrossRef]

66. Sharma, A.; Ghosh, D.; Divekar, N.; Gore, M.; Gochhait, S.; Shireshi, S.S. Comparing the socio-economic implications of the 1918 Spanish flu and the COVID-19 pandemic in India: A systematic review of literature. Int. Soc. Sci. J. 2021, in press. [CrossRef] [PubMed]

67. Plotkin, S.A. History of Vaccine Development; Springer Science \& Business Media: Berlin/Heidelberg, Germany, 2011.

68. Larson, H.J.; Cooper, L.Z.; Eskola, J.; Katz, S.L.; Ratzan, S. Addressing the vaccine confidence gap. Lancet 2011, 378, 526-535. [CrossRef]

69. Ulmer, J.B.; Valley, U.; Rappuoli, R. Vaccine manufacturing: Challenges and solutions. Nat. Biotechnol. 2006, $24,1377-1383$. [CrossRef]

70. Josefsberg, J.O.; Buckland, B. Vaccine process technology. Biotechnol. Bioeng. 2012, 109, 1443-1460. [CrossRef] [PubMed]

71. Clem, A.S. Fundamentals of vaccine immunology. J. Glob. Infect. Dis. 2011, 3, 73. [CrossRef] [PubMed]

72. Apostolopoulos, V.; Thalhammer, T.; Tzakos, A.G.; Stojanovska, L. Targeting antigens to dendritic cell receptors for vaccine development. J. Drug Deliv. 2013, 2013, 869718. [CrossRef]

73. Scheinberg, D.A.; McDevitt, M.R.; Dao, T.; Mulvey, J.J.; Feinberg, E.; Alidori, S. Carbon nanotubes as vaccine scaffolds. Adv. Drug Deliv. Rev. 2013, 65, 2016-2022. [CrossRef] 
74. Christensen, D.; Henriksen-Lacey, M.; Kamath, A.T.; Lindenstrøm, T.; Korsholm, K.S.; Christensen, J.P.; Rochat, A.; Lambert, P.; Andersen, P.; Siegrist, C.; et al. A cationic vaccine adjuvant based on a saturated quaternary ammonium lipid have different in vivo distribution kinetics and display a distinct CD4 T cell-inducing capacity compared to its unsaturated analog. J. Control. Release 2012, 160, 468-476. [CrossRef]

75. Klucker, M.F.; Dalençon, F.; Probeck, P.; Haensler, J. AF03, an alternative squalene emulsion-based vaccine adjuvant prepared by a phase inversion temperature method. J. Pharm. Sci. 2012, 101, 4490-4500. [CrossRef]

76. Pawar, D.; Mangal, S.; Goswami, R.; Jaganathan, K.S. Development and characterization of surface modified PLGA nanoparticles for nasal vaccine delivery: Effect of mucoadhesive coating on antigen uptake and immune adjuvant activity. Eur. J. Pharm. Biopharm. 2013, 85, 550-559. [CrossRef] [PubMed]

77. Borges, O.; Borchard, G.; Verhoef, J.C.; Sousa, A.D.; Junginger, H.E. Preparation of coated nanoparticles for a new mucosal vaccine delivery system. Int. J. Pharm. 2005, 299, 155-166. [CrossRef] [PubMed]

78. Gupta, P.N.; Vyas, S.P. Investigation of lectinized liposomes as M-cell targeted carrier-adjuvant for mucosal immunization. Colloids Surf. B Biointerfaces 2011, 82, 118-125. [CrossRef] [PubMed]

79. Ulery, B.D.; Kumar, D.; Ramer-Tait, A.E.; Metzger, D.W.; Wannemuehler, M.J.; Narasimhan, B. Design of a protective single-dose intranasal nanoparticle-based vaccine platform for respiratory infectious diseases. PLoS ONE. 2011, 6, e17642. [CrossRef] [PubMed]

80. Khandker, S.S.; Shakil, M.; Hossen, M. Gold Nanoparticles; Potential Nanotheranostic Agent in Breast Cancer: A Comprehensive Review with Systematic Search Strategy. Curr. Drug Metab. 2020, 21, 579-598. [CrossRef] [PubMed]

81. Yin, H.; Kanasty, R.L.; Eltoukhy, A.A.; Vagas, A.J.; Dorkin, R.; Anderson, D.G. Non-viral vectors for gene-based therapy. Nat. Rev. Genet. 2014, 15, 541-555. [CrossRef]

82. Gregory, A.E.; Williamson, D.; Titball, R. Vaccine delivery using nanoparticles. Front. Cell. Infect. Microbiol. 2013, 3, 13. [CrossRef]

83. Panyam, J.; Labhasetwar, V. Biodegradable nanoparticles for drug and gene delivery to cells and tissue. Adv. Drug Deliv. Rev. 2003, 55, 329-347. [CrossRef]

84. Shen, Y.; Hao, T.; Ou, S.; Hu, C.; Chen, L. Applications and perspectives of nanomaterials in novel vaccine development. MedChem Comm 2018, 9, 226-238. [CrossRef]

85. Qi, F.; Wu, J.; Li, H.; Ma, G. Recent research and development of PLGA/PLA microspheres/nanoparticles: A review in scientific and industrial aspects. Front. Chem. Sci. Eng. 2019, 13, 14-27. [CrossRef]

86. Sainz, V.; Conniot, J.; Matos, A.I.; Peres, C.; Zupancic, E.; Moura, L.; Silva, L.C.; Florindo, H.F.; Gaspar, R.S. Regulatory aspects on nanomedicines. Biochem. Biophys. Res. Commun. 2015, 468, 504-510. [CrossRef]

87. Bonam, S.R.; Kotla, N.G.; Bohara, R.A.; Rochev, Y.; Webster, T.J.; Bayry, J. Potential immuno-nanomedicine strategies to fight COVID-19 like pulmonary infections. Nano Today 2020, 36, 101051. [CrossRef] [PubMed]

88. Malabadi, R.B.; Meti, N.T.; Chalannavar, R.K. Applications of nanotechnology in vaccine development for coronavirus (SARSCoV-2) disease (COVID-19). Int. J. Res. Sci. Innov. 2021, 8, 191-198.

89. Kames, J.; Holcomb, D.D.; Kimchi, O.; DiCuccio, M.; Hamasaki-Katagiri, N.; Wang, T.; Komar, A.A.; Alexaki, A.; Kimchi-Sarfaty, C. Sequence analysis of SARS-CoV-2 genome reveals features important for vaccine design. Sci. Rep. 2020, 10, 15643. [CrossRef]

90. Khailany, R.A.; Safdar, M.; Ozaslan, M. Genomic characterization of a novel SARS-CoV-2. Gene Rep. 2020, 19, 100682. [CrossRef]

91. Kim, D.; Lee, J.-Y.; Yang, J.-S.; Kim, J.W.; Kim, N.; Chang, H. The architecture of SARS-CoV-2 transcriptome. Cell 2020, 181, 914-921. [CrossRef]

92. Ella, R.; Reddy, S.; Jogdand, H.; Sarangi, V.; Ganneru, B.; Prasad, S.; Das, D.; Raju, D.; Praturi, U.; Sapkal, G.; et al. Safety and immunogenicity of an inactivated SARS-CoV-2 vaccine, BBV152: Interim results from a double-blind, randomised, multicentre, phase 2 trial, and 3-month follow-up of a double-blind, randomised phase 1 trial. Lancet Infect. Dis. 2021, 21, 950-961. [CrossRef]

93. Folegatti, P.M.; Ewer, K.J.; Aley, P.K.; Angus, B.; Becker, S.; Belij-Rammerstorfer, S.; Bellamy, D.; Bibi, S.; Bittaye, M.; Clutterbuck, E.A. Safety and immunogenicity of the ChAdOx1 nCoV-19 vaccine against SARS-CoV-2: A preliminary report of a phase $1 / 2$, single-blind, randomised controlled trial. Lancet 2020, 396, 467-478. [CrossRef]

94. Polack, F.P.; Thomas, S.J.; Kitchin, N.; Absalon, J.; Gurtman, A.; Lockhart, S.; Perez, J.L.; Marc, G.P.; Moreira, E.D.; Zerbini, C. Safety and Efficacy of the BNT162b2 mRNA COVID-19 Vaccine. N. Engl. J. Med. 2020, 383, 2603-2615. [CrossRef]

95. NHI PM. Novavax Vaccine (NVX-CoV2373): Promising Phase-III Human Clinical-Trial Results against COVID-19. Available online: https:/ / neucradhealth.in/language/en/novavax-vaccine-nvx-cov2373-promising-phase-iii-human-clinical-trial-resultsagainst-covid-19/ (accessed on 20 February 2021).

96. Abena, P.M.; Decloedt, E.H.; Bottieau, E.; Suleman, F.; Adejumo, P.; Sam-Agudu, N.; Tamfum, J.-J.M.; Seydi, M.; Eholie, S.P.; Mills, E.J.; et al. Chloroquine and hydroxychloroquine for the prevention or treatment of COVID-19 in Africa: Caution for inappropriate off-label use in healthcare settings. Am. J. Trop. Med. Hyg. 2020, 102, 1184-1188. [CrossRef] [PubMed]

97. Godman, B.; Haque, M.; Islam, S.; Iqbal, S.; Urmi, U.L.; Kamal, Z.M.; Shuvo, S.A.; Rahman, A.; Kamal, M.; Haque, M.; et al. Rapid assessment of price instability and paucity of medicines and protection for COVID-19 across Asia: Findings and public health implications for the future. Front. Public Health 2020, 8, 585832. [CrossRef]

98. Godman, B. Combating COVID-19: Lessons learnt particularly among developing countries and the implications. Bangladesh J. Med Sci. 2020, 19, S103-S108. [CrossRef]

99. Lin, C.; Tu, P.; Beitsch, L.M. Confidence and receptivity for COVID-19 vaccines: A rapid systematic review. Vaccines 2021, 9, 16. [CrossRef] [PubMed] 
100. Islam, M.S.; Kamal, A.-H.M.; Kabir, A.; Southern, D.L.; Khan, S.H.; Hasan, S.M.; Sarkar, T.; Sharmin, S.; Das, S.; Roy, T.; et al. COVID-19 vaccine rumors and conspiracy theories: The need for cognitive inoculation against misinformation to improve vaccine adherence. PLoS ONE 2021, 16, e0251605. [CrossRef] [PubMed]

101. Moher, D.; Liberati, A.; Tetzlaff, J.; Altman, D.G.; Altman, D.; Atkins, D.; Barbour, V.; Barrowman, N.; Berlin, J.A.; Clark, J.; et al. Preferred reporting items for systematic reviews and meta-analyses: The PRISMA statement. PLoS Med. 2009, 6, e1000097. [CrossRef]

102. (NIH) USDoHHS. Study Quality Assessment Tools. 2021. Available online: https://www.nhlbi.nih.gov/health-topics/studyquality-assessment-tools (accessed on 14 May 2021).

103. Stauffer, F.; El-Bacha, T.; Da Poian, A.T. Advances in the development of inactivated virus vaccines. Recent Pat. Anti Infect. Drug Discov. 2006, 1, 291-296. [CrossRef]

104. Martin, J.E.; Graham, B.S. Immunization against Viral Diseases. In Clinical Virology, 3rd ed.; American Society of Microbiology: Washington, DC, USA, 2009.

105. Green, M.D.; Al-Humadi, N.H. Preclinical toxicology of vaccines. In A Comprehensive Guide to Toxicology in Nonclinical Drug Development; Elsevier: Amsterdam, The Netherlands, 2017; pp. 709-735.

106. Goldsmith, C.S.; Tatti, K.M.; Ksiazek, T.G.; Rollin, P.E.; Comer, J.A.; Lee, W.W.; Rota, P.A.; Bankamp, B.; Bellini, W.J.; Zaki, S.R. Ultrastructural characterization of SARS coronavirus. Emerg. Infect. Dis. 2004, 10, 320. [CrossRef]

107. Centers for Disease Control and Prevention. Outbreak of severe acute respiratory syndrome—Worldwide, 2003. MMWR Morb. Mortal. Wkly. Rep. 2003, 52, 226-228.

108. See, R.H.; Petric, M.; Lawrence, D.J.; Mok, C.; Rowe, T.; Zitzow, L.A.; Karunakaran, K.P.; Voss, T.G.; Brunham, R.C.; Gauldie, J.; et al. Severe acute respiratory syndrome vaccine efficacy in ferrets: Whole killed virus and adenovirus-vectored vaccines. J. Gen. Virol. 2008, 89, 2136-2146. [CrossRef]

109. Zheng, B.J.; Guan, Y.; Wong, K.H.; Wong, K.L.; Young, B.W.; Lu, L.W.; Lee, S.S. SARS-related virus predating SARS outbreak, Hong Kong. Emerg. Infect. Dis. 2004, 10, 176. [CrossRef] [PubMed]

110. Kobinger, G.P.; Figueredo, J.M.; Rowe, T.; Zhi, Y.; Gao, G.; Sanmiguel, J.C.; Bell, P.; Wivel, N.A.; Zitzow, L.A.; Flieder, D.B.; et al. Adenovirus-based vaccine prevents pneumonia in ferrets challenged with the SARS coronavirus and stimulates robust immune responses in macaques. Vaccine 2007, 25, 5220-5231. [CrossRef]

111. Ter Meulen, J.; Bakker, A.B.; Van Den Brink, E.N.; Weverling, G.J.; Martina, B.E.; Haagmans, B.L.; Kuiken, T.; de Kruif, J.; Preiser, W.; Spaan, W.; et al. Human monoclonal antibody as prophylaxis for SARS coronavirus infection in ferrets. Lancet 2004, 363, 2139-2141. [CrossRef]

112. Tang, L.; Zhu, Q.; Qin, E.; Yu, M.; Ding, Z.; Shi, H.; Cheng, X.; Wang, C.; Chang, G.; Zhu, Q.; et al. Inactivated SARS-CoV vaccine prepared from whole virus induces a high level of neutralizing antibodies in BALB/c mice. DNA Cell Biol. 2004, 23, 391-394. [CrossRef] [PubMed]

113. Sheahan, T.P.; Sims, A.C.; Leist, S.R.; Schäfer, A.; Won, J.; Brown, A.J.; Montgomery, S.A.; Hogg, A.; Babusis, D.; Clarke, M.O.; et al. Comparative therapeutic efficacy of remdesivir and combination lopinavir, ritonavir, and interferon beta against MERS-CoV. Nat. Commun. 2020, 11, 222. [CrossRef]

114. Gastanaduy, P.A. Update: Severe respiratory illness associated with Middle East respiratory syndrome coronavirus (MERS-CoV)Worldwide, 2012-2013. MMWR Morb. Mortal. Wkly. Rep. 2013, 62, 480.

115. Zaki, A.M.; Van Boheemen, S.; Bestebroer, T.M.; Osterhaus, A.D.; Fouchier, R.A. Isolation of a novel coronavirus from a man with pneumonia in Saudi Arabia. N. Engl. J. Med. 2012, 367, 1814-1820. [CrossRef]

116. Memish, Z.A.; Mishra, N.; Olival, K.J.; Fagbo, S.F.; Kapoor, V.; Epstein, J.H.; Alhakeem, R.; Durosinloun, A.; Al Asmari, M.; Islam, A.; et al. Middle East respiratory syndrome coronavirus in bats, Saudi Arabia. Emerg. Infect. Dis. 2013, 19, 1819. [CrossRef]

117. Haagmans, B.L.; Al Dhahiry, S.H.; Reusken, C.B.; Raj, V.S.; Galiano, M.; Myers, R.; Godeke, G.J.; Jonges, M.; Farag, E.; Diab, A.; et al. Middle East respiratory syndrome coronavirus in dromedary camels: An outbreak investigation. Lancet Infect. Dis. 2014, 14, 140-145. [CrossRef]

118. Deng, Y.; Lan, J.; Bao, L.; Huang, B.; Ye, F.; Chen, Y.; Yao, Y.; Wang, W.; Qin, C.; Tan, W. Enhanced protection in mice induced by immunization with inactivated whole viruses compare to spike protein of middle east respiratory syndrome coronavirus. Emerg. Microbes Infect. 2018, 7, 1-10. [CrossRef]

119. Bleibtreu, A.; Bertine, M.; Bertin, C.; Houhou-Fidouh, N.; Visseaux, B. Focus on Middle East respiratory syndrome coronavirus (MERS-CoV). Med. Mal. Infect. 2019, 50, 243-251. [CrossRef]

120. Xia, S.; Zhang, Y.; Wang, Y.; Wang, H.; Yang, Y.; Gao, G.F.; Tan, W.; Wu, G.; Xu, M.; Lou, Z.; et al. Safety and immunogenicity of an inactivated SARS-CoV-2 vaccine, BBIBP-CorV: A randomised, double-blind, placebo-controlled, phase 1/2 trial. Lancet Infect. Dis. 2021, 21, 39-51. [CrossRef]

121. Wang, H.; Zhang, Y.; Huang, B.; Deng, W.; Quan, Y.; Wang, W.; Xu, W.; Zhao, Y.; Li, N.; Zhang, J.; et al. Development of an inactivated vaccine candidate, BBIBP-CorV, with potent protection against SARS-CoV-2. Cell 2020, 182, 713-721. [CrossRef] [PubMed]

122. Zhang, Y.; Zeng, G.; Pan, H.; Li, C.; Hu, Y.; Chu, K.; Han, W.; Chen, Z.; Tang, R.; Yin, W.; et al. Safety, tolerability, and immunogenicity of an inactivated SARS-CoV-2 vaccine in healthy adults aged 18-59 years: A randomised, double-blind, placebo-controlled, phase $1 / 2$ clinical trial. Lancet Infect. Dis. 2021, 21, 181-192. [CrossRef] 
123. Wu, Z.; Hu, Y.; Xu, M.; Chen, Z.; Yang, W.; Jiang, Z.; Li, M.; Jin, H.; Cui, G.; Chen, P.; et al. Safety, tolerability, and immunogenicity of an inactivated SARS-CoV-2 vaccine (CoronaVac) in healthy adults aged 60 years and older: A randomised, double-blind, placebo-controlled, phase $1 / 2$ clinical trial. Lancet Infect. Dis. 2021, 21, 803-812. [CrossRef]

124. Tanriover, M.D.; Doğanay, H.L.; Akova, M.; Güner, H.R.; Azap, A.; Akhan, S.; Köse, Ş.; Erdinç, F.Ş.; Akalın, E.H.; Tabak, Ö.F.; et al. Efficacy and safety of an inactivated whole-virion SARS-CoV-2 vaccine (CoronaVac): Interim results of a double-blind, randomised, placebo-controlled, phase 3 trial in Turkey. Lancet 2021, 398, 213-222. [CrossRef]

125. Ganneru, B.; Jogdand, H.; Daram, V.K.; Das, D.; Molugu, N.R.; Prasad, S.D.; Kannappa, S.V.; Ella, K.M.; Ravikrishnan, R.; Awasthi, A.; et al. Th1 Skewed immune response of Whole Virion Inactivated SARS CoV 2 Vaccine and its safety evaluation. iScience 2021, 24, 102298. [CrossRef]

126. Mohandas, S.; Yadav, P.D.; Shete-Aich, A.; Abraham, P.; Vadrevu, K.M.; Sapkal, G.; Mote, C.; Nyayanit, D.; Gupta, N.; Srinivas, V.K.; et al. Immunogenicity and protective efficacy of BBV152, whole virion inactivated SARS-CoV-2 vaccine candidates in the Syrian hamster model. iScience 2021, 24, 102054. [CrossRef]

127. Xia, S.; Duan, K.; Zhang, Y.; Zhao, D.; Zhang, H.; Xie, Z.; Li, X.; Peng, C.; Zhang, Y.; Zhang, W.; et al. Effect of an inactivated vaccine against SARS-CoV-2 on safety and immunogenicity outcomes: Interim analysis of 2 randomized clinical trials. JAMA 2020, 324, 951-960. [CrossRef]

128. Ella, R.; Reddy, S.; Blackwelder, W.; Potdar, V.; Yadav, P.; Sarangi, V.; Aileni, V.K.; Kanungo, S.; Rai, S.; Reddy, P.; et al. Efficacy, safety, and lot to lot immunogenicity of an inactivated SARS-CoV-2 vaccine (BBV152): A double-blind, randomised, controlled phase 3 trial. medRxiv 2021. [CrossRef]

129. Schlake, T.; Thess, A.; Fotin-Mleczek, M. Developing mRNA-vaccine technologies. RNA Biol. 2012, 9, 1319-1330. [CrossRef]

130. Mulligan, M.J.; Lyke, K.E.; Kitchin, N.; Absalon, J.; Gurtman, A.; Lockhart, S.; Neuzil, K.; Raabe, V.; Bailey, R.; Swanson, K.A.; et al. Phase I/II study of COVID-19 RNA vaccine BNT162b1 in adults. Nature 2020, 586, 589-593. [CrossRef]

131. Maruggi, G.; Chiarot, E.; Giovani, C.; Buccato, S.; Bonacci, S.; Frigimelica, E.; Margarit, I.; Geall, A.; Bensi, G.; Maione, D. Immunogenicity and protective efficacy induced by self-amplifying mRNA vaccines encoding bacterial antigens. Vaccine $\mathbf{2 0 1 7}, \mathbf{3 5}$, 361-368. [CrossRef] [PubMed]

132. Liang, F.; Lindgren, G.; Lin, A.; Thompson, E.A.; Ols, S.; Röhss, J.; John, S.; Hassett, K.; Yuzhakov, O.; Bahl, K.; et al. Efficient Targeting and Activation of Antigen-Presenting Cells In Vivo after Modified mRNA Vaccine Administration in Rhesus Macaques. Molecular therapy. J. Am. Soc. Gene Ther. 2017, 25, 2635-2647. [CrossRef] [PubMed]

133. Pepini, T.; Pulichino, A.M.; Carsillo, T.; Carlson, A.L.; Sari-Sarraf, F.; Ramsauer, K.; Debasitis, J.C.; Maruggi, G.; Otten, G.R.; Geall, A.J.; et al. Induction of an IFN-Mediated Antiviral Response by a Self-Amplifying RNA Vaccine: Implications for Vaccine Design. J. Immunol. 2017, 198, 4012-4024. [CrossRef] [PubMed]

134. Edwards, D.K.; Jasny, E.; Yoon, H.; Horscroft, N.; Schanen, B.; Geter, T.; Fotin-Mleczek, M.; Petsch, B.; Wittman, V. Adjuvant effects of a sequence-engineered mRNA vaccine: Translational profiling demonstrates similar human and murine innate response. J. Transl. Med. 2017, 15, 1. [CrossRef] [PubMed]

135. Karikó, K.; Muramatsu, H.; Welsh, F.A.; Ludwig, J.; Kato, H.; Akira, S.; Weissman, D. Incorporation of pseudouridine into mRNA yields superior nonimmunogenic vector with increased translational capacity and biological stability. Mol. Ther. J. Am. Soc. Gene Ther. 2008, 16, 1833-1840. [CrossRef]

136. Thess, A.; Grund, S.; Mui, B.L.; Hope, M.J.; Baumhof, P.; Fotin-Mleczek, M.; Schlake, T. Sequence-engineered mRNA Without Chemical Nucleoside Modifications Enables an Effective Protein Therapy in Large Animals. Mol. Ther. J. Am. Soc. Gene Ther. 2015, 23, 1456-1464. [CrossRef]

137. Karikó, K.; Muramatsu, H.; Ludwig, J.; Weissman, D. Generating the optimal mRNA for therapy: HPLC purification eliminates immune activation and improves translation of nucleoside-modified, protein-encoding mRNA. Nucleic Acids Res. 2011, 39, e142 [CrossRef]

138. Guan, S.; Rosenecker, J. Nanotechnologies in delivery of mRNA therapeutics using nonviral vector-based delivery systems. Gene Ther. 2017, 24, 133-143. [CrossRef]

139. Kauffman, K.J.; Webber, M.J.; Anderson, D.G. Materials for non-viral intracellular delivery of messenger RNA therapeutics. J. Control. Release Off. J. Control. Release Soc. 2016, 240, 227-234. [CrossRef] [PubMed]

140. Begum, J.; Mir, N.A.; Dev, K.; Buyamayum, B.; Wani, M.Y.; Raza, M. Challenges and prospects of COVID-19 vaccine development based on the progress made in SARS and MERS vaccine development. Transbound. Emerg. Dis. 2020, 68, 1111-1124. [CrossRef] [PubMed]

141. Xu, S.; Yang, K.; Li, R.; Zhang, L. mRNA Vaccine Era-Mechanisms, Drug Platform and Clinical Prospection. Int. J. Mol. Sci. 2020, 21, 6582. [CrossRef]

142. Bahl, K.; Senn, J.J.; Yuzhakov, O.; Bulychev, A.; Brito, L.A.; Hassett, K.J.; Laska, M.E.; Smith, M.; Almarsson, Ö.; Thompson, J.; et al. Preclinical and Clinical Demonstration of Immunogenicity by mRNA Vaccines against H10N8 and H7N9 Influenza Viruses. Mol. Ther. J. Am. Soc. Gene Ther. 2017, 25, 1316-1327. [CrossRef] [PubMed]

143. Feldman, R.A.; Fuhr, R.; Smolenov, I.; Mick Ribeiro, A.; Panther, L.; Watson, M.; Senn, J.J.; Smith, M.; Almarsson, Ö.; Pujar, H.S.; et al. mRNA vaccines against $\mathrm{H} 10 \mathrm{~N} 8$ and H7N9 influenza viruses of pandemic potential are immunogenic and well tolerated in healthy adults in phase 1 randomized clinical trials. Vaccine 2019, 37, 3326-3334. [CrossRef]

144. Pardi, N.; Hogan, M.J.; Porter, F.W.; Weissman, D. mRNA vaccines-A new era in vaccinology. Nat. Rev. Drug Discov. 2018, 17, 261-279. [CrossRef] 
145. Khurana, A.; Allawadhi, P.; Khurana, I.; Allwadhi, S.; Weiskirchen, R.; Banothu, A.K.; Chhabra, D.; Joshi, K.; Bharani, K.K. Role of nanotechnology behind the success of mRNA vaccines for COVID-19. Nano Today 2021, 38, 101142. [CrossRef]

146. Shapiro, R.S. COVID-19 vaccines and nanomedicine. Int. J. Dermatol. 2021, 60, 1047-1052. [CrossRef]

147. Tang, Z.; Zhang, X.; Shu, Y.; Guo, M.; Zhang, H.; Tao, W. Insights from nanotechnology in COVID-19 treatment. Nano Today 2021, 36, 101019. [CrossRef]

148. Allawadhi, P.; Khurana, A.; Allwadhi, S.; Joshi, K.; Packirisamy, G.; Bharani, K.K. Nanoceria as a possible agent for the management of COVID-19. Nano Today 2020, 35, 100982. [CrossRef]

149. Bouazzaoui, A.; Abdellatif, A.A.; Al-Allaf, F.A.; Bogari, N.M.; Al-Dehlawi, S.; Qari, S.H. Strategies for vaccination: Conventional vaccine approaches versus new-generation strategies in combination with adjuvants. Pharmaceutics 2021, 13, 140. [CrossRef] [PubMed]

150. Krammer, F. SARS-CoV-2 vaccines in development. Nature 2020, 586, 516-527. [CrossRef] [PubMed]

151. Anderson, R.M.; Vegvari, C.; Truscott, J.; Collyer, B.S. Challenges in creating herd immunity to SARS-CoV-2 infection by mass vaccination. Lancet 2020, 396, 1614-1616. [CrossRef]

152. Islam, M.A.; Xu, Y.; Tao, W.; Ubellacker, J.M.; Lim, M.; Aum, D.; Lee, G.Y.; Zhou, K.; Zope, H.; Yu, M.; et al. Restoration of tumour-growth suppression in vivo via systemic nanoparticle-mediated delivery of PTEN mRNA. Nat. Biomed. Eng. 2018, 2, 850-864. [CrossRef] [PubMed]

153. Kong, N.; Tao, W.; Ling, X.; Wang, J.; Xiao, Y.; Shi, S.; Ji, X.; Shajii, A.; Gan, S.T.; Kim, N.Y.; et al. Synthetic mRNA nanoparticlemediated restoration of p53 tumor suppressor sensitizes p53-deficient cancers to mTOR inhibition. Sci. Transl. Med. 2019, 11, eaaw1565. [CrossRef]

154. Pardi, N.; Tuyishime, S.; Muramatsu, H.; Kariko, K.; Mui, B.L.; Tam, Y.K.; Madden, T.D.; Hope, M.J.; Weissman, D. Expression kinetics of nucleoside-modified mRNA delivered in lipid nanoparticles to mice by various routes. J. Control. Release 2015, 217, 345-351. [CrossRef] [PubMed]

155. Wadhwa, A.; Aljabbari, A.; Lokras, A.; Foged, C.; Thakur, A. Opportunities and challenges in the delivery of mRNA-based vaccines. Pharmaceutics 2020, 12, 102. [CrossRef]

156. Chandler, M.; Johnson, M.B.; Panigaj, M.; Afonin, K.A. Innate immune responses triggered by nucleic acids inspire the design of immunomodulatory nucleic acid nanoparticles (NANPs). Curr. Opin. Biotechnol. 2020, 63, 8-15. [CrossRef]

157. Nel, A.E.; Miller, J.F. Nano-enabled COVID-19 vaccines: Meeting the challenges of durable antibody plus cellular immunity and immune escape. ACS Nano 2021, 15, 5793-5818. [CrossRef]

158. Jackson, L.A.; Anderson, E.J.; Rouphael, N.G.; Roberts, P.C.; Makhene, M.; Coler, R.N.; McCullough, M.P.; Chappell, J.D.; Denison, M.R.; Stevens, L.J.; et al. An mRNA Vaccine against SARS-CoV-2-Preliminary Report. N. Engl. J. Med. 2020, 383, 1920-1931. [CrossRef]

159. Chu, L.; McPhee, R.; Huang, W.; Bennett, H.; Pajon, R.; Nestorova, B.; Leav, B.; mRNA-1273 Study Group. A preliminary report of a randomized controlled phase 2 trial of the safety and immunogenicity of mRNA-1273 SARS-CoV-2 vaccine. Vaccine 2021, 39, 2791-2799. [CrossRef] [PubMed]

160. Baden, L.R.; El Sahly, H.M. Efficacy and Safety of the mRNA-1273 SARS-CoV-2 Vaccine. N. Engl. J. Med. 2021, $384,403-416$. [CrossRef] [PubMed]

161. Walsh, E.E.; Frenck, R.W., Jr.; Falsey, A.R.; Kitchin, N.; Absalon, J.; Gurtman, A.; Lockhart, S.; Neuzil, K.; Mulligan, M.J.; Bailey, R.; et al. Safety and Immunogenicity of Two RNA-Based COVID-19 Vaccine Candidates. N. Engl. J. Med. 2020, 383, 2439-2450. [CrossRef]

162. Balakrishnan, V.S. The arrival of Sputnik V. Lancet Infect. Dis. 2020, 20, 1128. [CrossRef]

163. Li, J.; Hui, A.; Zhang, X.; Yang, Y.; Tang, R.; Ye, H.; Ji, R.; Lin, M.; Zhu, Z.; Türeci, Ö.; et al. Safety and immunogenicity of the SARS-CoV-2 BNT162b1 mRNA vaccine in younger and older Chinese adults: A randomized, placebo-controlled, double-blind phase 1 study. Nat. Med. 2021, 27, 1062-1070. [CrossRef] [PubMed]

164. Frenck, R.W., Jr.; Klein, N.P.; Kitchin, N.; Gurtman, A.; Absalon, J.; Lockhart, S.; Perez, J.L.; Walter, E.B.; Senders, S.; Bailey, R.; et al. Safety, immunogenicity, and efficacy of the BNT162b2 COVID-19 vaccine in adolescents. N. Engl. J. Med. 2021, 385, 239-250. [CrossRef]

165. Manisty, C.; Otter, A.D.; Treibel, T.A.; McKnight, Á.; Altmann, D.M.; Brooks, T.; Noursadeghi, M.; Boyton, R.J.; Semper, A.; Moon, J.C. Antibody response to first BNT162b2 dose in previously SARS-CoV-2-infected individuals. Lancet 2021, 397, $1057-1058$. [CrossRef]

166. Perkmann, T.; Perkmann-Nagele, N.; Koller, T.; Mucher, P.; Radakovics, A.; Wolzt, M.; Wagner, O.F.; Binder, C.J.; Haslacher, H. Serum antibody response to BNT162b2 after natural SARS-CoV-2 infection. Eur. J. Clin. Investig. 2021, 51, e13632. [CrossRef] [PubMed]

167. Ebinger, J.E.; Fert-Bober, J.; Printsev, I.; Wu, M.; Sun, N.; Prostko, J.C.; Frias, E.C.; Stewart, J.L.; Van Eyk, J.E.; Braun, J.G.; et al. Antibody responses to the BNT162b2 mRNA vaccine in individuals previously infected with SARS-CoV-2. Nat. Med. 2021, 27, 981-984. [CrossRef]

168. Buonfrate, D.; Piubelli, C.; Gobbi, F.; Martini, D.; Bertoli, G.; Ursini, T.; Moro, L.; Ronzoni, N.; Angheben, A.; Rodari, P.; et al. Antibody response induced by the BNT162b2 mRNA COVID-19 vaccine in a cohort of health-care workers, with or without prior SARS-CoV-2 infection: A prospective study. Clin. Microbiol. Infect. 2021, in press. [CrossRef] 
169. Bradley, T.; Grundberg, E.; Selvarangan, R.; LeMaster, C.; Fraley, E.; Banerjee, D.; Belden, B.; Louiselle, D.; Nolte, N.; Biswell, R.; et al. Antibody Responses after a Single Dose of SARS-CoV-2 mRNA Vaccine. N. Engl. J. Med. 2021, 384, 1959-1961. [CrossRef] [PubMed]

170. Walsh, G. Pharmaceutical Biotechnology: Concepts and Applications; John Wiley \& Sons: Hoboken, NJ, USA, 2013.

171. Kapila, K. Kuby Immunology, 4th Edition year 2000. Med. J. Armed Forces India 2004, 60, 91. [CrossRef]

172. Wold, W.S.; Toth, K. Adenovirus vectors for gene therapy, vaccination and cancer gene therapy. Curr. Gene Ther. 2013, 13, 421-433. [CrossRef] [PubMed]

173. Tatsis, N.; Ertl, H.C. Adenoviruses as vaccine vectors. Mol. Ther. J. Am. Soc. Gene Ther. 2004, 10, 616-629. [CrossRef]

174. Ghebremedhin, B. Human adenovirus: Viral pathogen with increasing importance. Eur. J. Microbiol. Immunol. 2014, 4, 26-33. [CrossRef]

175. Afkhami, S.; Yao, Y.; Xing, Z. Methods and clinical development of adenovirus-vectored vaccines against mucosal pathogens. Mol. Ther. Methods Clin. Dev. 2016, 3, 16030. [CrossRef]

176. Kim, E.; Okada, K.; Kenniston, T.; Raj, V.S.; AlHajri, M.M.; Farag, E.A.; AlHajri, F.; Osterhaus, A.D.; Haagmans, B.L.; Gambotto, A.; et al. Immunogenicity of an adenoviral-based Middle East Respiratory Syndrome coronavirus vaccine in BALB/c mice. Vaccine 2014, 32, 5975-5982. [CrossRef]

177. Kovyrshina, A.; Dolzhikova, I.; Grousova, D.; Balyasin, M.V.; Botikov, A.G.; Panina, L.V.; Gordeichuk, I.V.; Gulyaev, S.A.; Zubkova, O.V.; Ozharovskaya, T.A.; et al. A heterologous virus-vectored vaccine for prevention of Middle East respiratory syndrome induces long protective immune response against MERS-CoV. Immunology 2020, 41, 135-143. [CrossRef]

178. Zhu, F.C.; Li, Y.H.; Guan, X.H.; Hou, L.H.; Wang, W.J.; Li, J.X.; Wu, S.P.; Wang, B.S.; Wang, Z.; Wang, L.; et al. Safety, tolerability, and immunogenicity of a recombinant adenovirus type- 5 vectored COVID-19 vaccine: A dose-escalation, open-label, non-randomised, first-in-human trial. Lancet 2020, 395, 1845-1854. [CrossRef]

179. Zhu, F.C.; Guan, X.H.; Li, Y.H.; Huang, J.Y.; Jiang, T.; Hou, L.H.; Li, J.X.; Yang, B.F.; Wang, L.; Wang, W.J.; et al. Immunogenicity and safety of a recombinant adenovirus type-5-vectored COVID-19 vaccine in healthy adults aged 18 years or older: A randomised, double-blind, placebo-controlled, phase 2 trial. Lancet 2020, 396, 479-488. [CrossRef]

180. Wu, S.; Huang, J.; Zhang, Z.; Wu, J.; Zhang, J.; Hu, H.; Zhu, T.; Zhang, J.; Luo, L.; Fan, P.; et al. Safety, tolerability, and immunogenicity of an aerosolised adenovirus type- 5 vector-based COVID-19 vaccine (Ad5-nCoV) in adults: Preliminary report of an open-label and randomised phase 1 clinical trial. Lancet Infect. Dis. 2021, in press. [CrossRef]

181. Ewer, K.J.; Barrett, J.R.; Belij-Rammerstorfer, S.; Sharpe, H.; Makinson, R.; Morter, R.; Flaxman, A.; Wright, D.; Bellamy, D.; Bittaye, M.; et al. T cell and antibody responses induced by a single dose of ChAdOx1 nCoV-19 (AZD1222) vaccine in a phase $1 / 2$ clinical trial. Nat. Med. 2021, 27, 270-278. [CrossRef] [PubMed]

182. Barrett, J.R.; Belij-Rammerstorfer, S.; Dold, C.; Ewer, K.J.; Folegatti, P.M.; Gilbride, C.; Halkerston, R.; Hill, J.; Jenkin, D.; Stockdale, L.; et al. Phase 1/2 trial of SARS-CoV-2 vaccine ChAdOx1 nCoV-19 with a booster dose induces multifunctional antibody responses. Nat. Med. 2021, 27, 279-288. [CrossRef] [PubMed]

183. Ramasamy, M.N.; Minassian, A.M.; Ewer, K.J.; Flaxman, A.L.; Folegatti, P.M.; Owens, D.R.; Voysey, M.; Aley, P.K.; Angus, B.; Babbage, G.; et al. Safety and immunogenicity of ChAdOx1 nCoV-19 vaccine administered in a prime-boost regimen in young and old adults (COV002): A single-blind, randomised, controlled, phase 2/3 trial. Lancet 2020, 396, 1979-1993. [CrossRef]

184. Voysey, M.; Clemens, S.A.C.; Madhi, S.A.; Weckx, L.Y.; Folegatti, P.M.; Aley, P.K.; Angus, B.; Baillie, V.L.; Barnabas, S.L.; Bhorat, Q.E.; et al. Safety and efficacy of the ChAdOx1 nCoV-19 vaccine (AZD1222) against SARS-CoV-2: An interim analysis of four randomised controlled trials in Brazil, South Africa, and the UK. Lancet 2021, 397, 99-111. [CrossRef]

185. Emary, K.R.; Golubchik, T.; Aley, P.K.; Ariani, C.V.; Angus, B.; Bibi, S.; Blane, B.; Bonsall, D.; Cicconi, P.; Charlton, S.; et al. Efficacy of ChAdOx1 nCoV-19 (AZD1222) vaccine against SARS-CoV-2 variant of concern 202012/01 (B.1.1.7): An exploratory analysis of a randomised controlled trial. Lancet 2021, 397, 1351-1362. [CrossRef]

186. Madhi, S.A.; Baillie, V.; Cutland, C.L.; Voysey, M.; Koen, A.L.; Fairlie, L.; Padayachee, S.D.; Dheda, K.; Barnabas, S.L.; Bhorat, Q.E.; et al. Efficacy of the ChAdOx1 nCoV-19 COVID-19 vaccine against the B. 1.351 variant. N. Engl. J. Med. 2021, 384, 1885-1898. [CrossRef] [PubMed]

187. Logunov, D.Y.; Dolzhikova, I.V.; Zubkova, O.V.; Tukhvatullin, A.I.; Shcheblyakov, D.V.; Dzharullaeva, A.S.; Grousova, D.M.; Erokhova, A.S.; Kovyrshina, A.V.; Botikov, A.; et al. Safety and immunogenicity of an rAd26 and rAd5 vector-based heterologous prime-boost COVID-19 vaccine in two formulations: Two open, non-randomised phase 1/2 studies from Russia. Lancet 2020, 396, 887-897. [CrossRef]

188. Custers, J.; Kim, D.; Leyssen, M.; Gurwith, M.; Tomaka, F.; Robertson, J.; Heijnen, E.; Condit, R.; Shukarev, G.; Heerwegh, D.; et al. Vaccines based on replication incompetent Ad26 viral vectors: Standardized template with key considerations for a risk/benefit assessment. Vaccine 2020, 39, 3081-3101. [CrossRef]

189. Pollard, A.J.; Launay, O.; Lelievre, J.-D.; Lacabaratz, C.; Grande, S.; Goldstein, N.; Robinson, C.; Gaddah, A.; Bockstal, V.; Wiedemann, A.; et al. Safety and immunogenicity of a two-dose heterologous Ad26. ZEBOV and MVA-BN-Filo Ebola vaccine regimen in adults in Europe (EBOVAC2): A randomised, observer-blind, participant-blind, placebo-controlled, phase 2 trial. Lancet Infect. Dis. 2021, 21, 493-506. [CrossRef]

190. Barouch, D.H.; Liu, J.; Peter, L.; Abbink, P.; Iampietro, M.J.; Cheung, A.; Alter, G.; Chung, A.; Dugast, A.S.; Frahm, N.; et al. Characterization of humoral and cellular immune responses elicited by a recombinant adenovirus serotype 26 HIV- 1 Env vaccine in healthy adults (IPCAVD 001). J. Infect. Dis. 2013, 207, 248-256. [CrossRef] [PubMed] 
191. Milligan, I.D.; Gibani, M.M.; Sewell, R.; Clutterbuck, E.A.; Campbell, D.; Plested, E.; Nuthall, E.; Voysey, M.; Silva-Reyes, L.; McElrath, M.J.; et al. Safety and Immunogenicity of Novel Adenovirus Type 26- and Modified Vaccinia Ankara-Vectored Ebola Vaccines: A Randomized Clinical Trial. JAMA 2016, 315, 1610-1623. [CrossRef]

192. Creech, C.B.; Dekker, C.L.; Ho, D.; Phillips, S.; Mackey, S.; Murray-Krezan, C.; Grazia Pau, M.; Hendriks, J.; Brown, V.; Dally, L.G.; et al. Randomized, placebo-controlled trial to assess the safety and immunogenicity of an adenovirus type 35-based circumsporozoite malaria vaccine in healthy adults. Hum Vaccin Immunother. 2013, 9, 2548-2557. [CrossRef] [PubMed]

193. Logunov, D.Y.; Dolzhikova, I.V.; Shcheblyakov, D.V.; Tukhvatulin, A.I.; Zubkova, O.V.; Dzharullaeva, A.S.; Kovyrshina, A.V.; Lubenets, N.L.; Grousova, D.M.; Erokhova, A.S.; et al. Safety and efficacy of an rAd26 and rAd5 vector-based heterologous prime-boost COVID-19 vaccine: An interim analysis of a randomised controlled phase 3 trial in Russia. Lancet 2021, 397, 671-681. [CrossRef]

194. Chang-Monteagudo, A.; Ochoa-Azze, R.; Climent-Ruiz, Y.; Macías-Abraham, C.; Rodríguez-Noda, L.; Valenzuela-Silva, C.; Sánchez-Ramírez, B.; Perez-Nicado, R.; González-Mugica, R.; Hernández-García, T.; et al. A single dose of SARS CoV 2 FINLAY FR 1A dimeric RBD recombinant vaccine enhances neutralization response in COVID-19 convalescents, with excellent safety profile. A preliminary report of an open-label phase 1 clinical trial. medRxiv 2021. [CrossRef]

195. Moore, A.C.; Dora, E.G.; Peinovich, N.; Tucker, K.P.; Lin, K.; Cortese, M.; Tucker, S.N. Pre-clinical studies of a recombinant adenoviral mucosal vaccine to prevent SARS-CoV-2 infection. bioRxiv 2020. [CrossRef]

196. Sadoff, J.; Le Gars, M.; Shukarev, G.; Heerwegh, D.; Truyers, C.; de Groot, A.M.; Stoop, J.; Tete, S.; Van Damme, W.; Leroux-Roels, I.; et al. Interim results of a phase 1-2a trial of Ad26.COV2.S COVID-19 vaccine. N. Engl. J. Med. 2021, 384, 1824-1835. [CrossRef]

197. Solforosi, L.; Kuipers, H.; Jongeneelen, M.; Rosendahl Huber, S.K.; van der Lubbe, J.; Dekking, L.; Czapska-Casey, D.N.; Izquierdo Gil, A.; Baert, M.; Drijver, J.; et al. Immunogenicity and efficacy of one and two doses of Ad26.COV2.S COVID vaccine in adult and aged NHP. J. Exp. Med. 2021, 218, e20202756. [CrossRef] [PubMed]

198. Sadoff, J.; Gray, G.; Vandebosch, A.; Cárdenas, V.; Shukarev, G.; Grinsztejn, B.; Goepfert, P.A.; Truyers, C.; Fennema, H.; Spiessens, B.; et al. Safety and efficacy of single-dose Ad26.COV2.S vaccine against COVID-19. N. Engl. J. Med. 2021, 384, $2187-2201$. [CrossRef]

199. Mehrabi, M.; Dounighi, N.M.; Mohammadi, M.; Mohammadi, M.; Masoudi, A. Nanoparticles and vaccine development. Pharm. Nanotechnol. 2020, 8, 6-21.

200. Zhao, L.; Seth, A.; Wibowo, N.; Zhao, C.X.; Mitter, N.; Yu, C.; Middelberg, A.P. Nanoparticle vaccines. Vaccine 2014, 32, 327-337. [CrossRef]

201. Kim, M.G.; Park, J.Y.; Shon, Y.; Kim, G.; Shim, G.; Oh, Y.K. Nanotechnology and vaccine development. Asian J. Pharm. Sci. 2014, 9 , 227-235. [CrossRef]

202. Oyewumi, M.O.; Kumar, A.; Cui, Z. Nano-microparticles as immune adjuvants: Correlating particle sizes and the resultant immune responses. Expert Rev. Vaccines 2010, 9, 1095-1107. [CrossRef] [PubMed]

203. Lepenies, B.; Lee, J.; Sonkaria, S. Targeting C-type lectin receptors with multivalent carbohydrate ligands. Adv. Drug Deliv. Rev. 2013, 65, 1271-1281. [CrossRef] [PubMed]

204. Raghuwanshi, D.; Mishra, V.; Suresh, M.R.; Kaur, K. A simple approach for enhanced immune response using engineered dendritic cell targeted nanoparticles. Vaccine 2012, 30, 7292-7299. [CrossRef] [PubMed]

205. Misumi, S.; Masuyama, M.; Takamune, N.; Nakayama, D.; Mitsumata, R.; Matsumoto, H.; Urata, N.; Takahashi, Y.; Muneoka, A.; Sukamoto, T.; et al. Targeted delivery of immunogen to primate M cells with tetragalloyl lysine dendrimer. J. Immunol. 2009, 182, 6061-6070. [CrossRef] [PubMed]

206. Yang, D. Application of Nanotechnology in the COVID-19 Pandemic. Int. J. Nanomed. 2021, 16, 623. [CrossRef] [PubMed]

207. Tian, J.-H.; Patel, N.; Haupt, R.; Zhou, H.; Weston, S.; Hammond, H.; Logue, J.; Portnoff, A.D.; Norton, J.; Guebre-Xabier, M.; et al. SARS-CoV-2 spike glycoprotein vaccine candidate NVX-CoV2373 immunogenicity in baboons and protection in mice. Nat. Commun. 2021, 12, 372. [CrossRef] [PubMed]

208. Heath, P.T.; Galiza, E.P.; Baxter, D.N.; Boffito, M.; Browne, D.; Burns, F.; Chadwick, D.R.; Clark, R.; Cosgrove, C.; Galloway, J.; et al. Safety and Efficacy of NVX-CoV2373 COVID-19 Vaccine. N. Engl. J. Med. 2021, 385, 1172-1183. [CrossRef]

209. Keech, C.; Albert, G.; Cho, I.; Robertson, A.; Reed, P.; Neal, S.; Plested, J.S.; Zhu, M.; Cloney-Clark, S.; Zhou, H.; et al. Phase 1-2 trial of a SARS-CoV-2 recombinant spike protein nanoparticle vaccine. N. Engl. J. Med. 2020, 383, 2320-2332. [CrossRef]

210. Medeiros-Ribeiro, A.C.; Aikawa, N.E.; Saad, C.G.; Yuki, E.; Pedrosa, T.; Fusco, S.; Rojo, P.T.; Pereira, R.; Shinjo, S.K.; Andrade, D.; et al. Immunogenicity and safety of the CoronaVac inactivated vaccine in patients with autoimmune rheumatic diseases: A phase 4 trial. Nat. Med. 2021, 27, 1744-1751. [CrossRef] [PubMed]

211. Karacin, C.; Eren, T.; Zeynelgil, E.; Imamoglu, G.I.; Altinbas, M.; Karadag, I.; Basal, F.B.; Bilgetekin, I.; Sutcuoglu, O.; Yazici, O.; et al. Immunogenicity and safety of the CoronaVac vaccine in patients with cancer receiving active systemic therapy. Future Oncol. 2021, 17, 4447-4456. [CrossRef] [PubMed]

212. Murat, K.; Ediz, T.E. The Effectiveness of Inactivated SARS-CoV-2 Vaccine (CoronaVac) on Antibody Response in Participants Aged 65 Years and Older. J. Med. Virol. 2021, 94, 173-177.

213. Seyahi, E.; Bakhdiyarli, G.; Oztas, M.; Kuskucu, M.A.; Tok, Y.; Sut, N.; Ozcifci, G.; Ozcaglayan, A.; Balkan, I.I.; Saltoglu, N.; et al. Antibody response to inactivated COVID-19 vaccine (CoronaVac) in immune-mediated diseases: A controlled study among hospital workers and elderly. Rheumatol. Int. 2021, 41, 1429-1440. [CrossRef] 
214. Soysal, A.; Gönüllü, E.; Karabayır, N.; Alan, S.; Atıcı, S.; Yıldız, İ; Engin, H.; Çivilibal, M.; Karaböcüoğlu, M. Comparison of immunogenicity and reactogenicity of inactivated SARS-CoV-2 vaccine (CoronaVac) in previously SARS-CoV-2 infected and uninfected health care workers. Hum Vaccin Immunother. online ahead of print. 2021, 1-5. [CrossRef] [PubMed]

215. Ranzani, O.T.; Hitchings, M.D.; Dorion, M.; D’Agostini, T.L.; de Paula, R.C.; de Paula, O.; Villela, E.; Torres, M.; de Oliveira, S.B.; Schulz, W.; et al. Effectiveness of the CoronaVac vaccine in older adults during a gamma variant associated epidemic of COVID-19 in Brazil: Test negative case-control study. BMJ 2021, 374, n2015. [CrossRef] [PubMed]

216. Fernández, J.; Bruneau, N.; Fasce, R.; Martín, H.S.; Balanda, M.; Bustos, P.; Ulloa, S.; Mora, J.; Ramírez, E. Neutralization of Alpha, Gamma, and D614G SARS-CoV-2 variants by CoronaVac vaccine-induced antibodies. J. Med. Virol. 2022, 94, 399-403. [CrossRef]

217. Jahromi, M.; Al Sheikh, M.H. Partial protection of Sinopharm vaccine against SARS COV2 during recent outbreak in Bahrain. Microb. Pathog. 2021, 158, 105086. [CrossRef]

218. Jeewandara, C.; Aberathna, I.S.; Pushpakumara, P.D.; Kamaladasa, A.; Guruge, D.; Jayathilaka, D.; Gunasekara, B.; Tanussiya, S.; Kuruppu, H.; Ranasinghe, T.; et al. Antibody and T cell responses to Sinopharm/BBIBP-CorV in naïve and previously infected individuals in Sri Lanka. medRxiv 2021. [CrossRef]

219. Yadav, P.D.; Sapkal, G.N.; Ella, R.; Sahay, R.R.; Nyayanit, D.A.; Patil, D.Y.; Deshpande, G.; Shete, A.M.; Gupta, N.; Mohan, V.K.; et al. Neutralization of Beta and Delta variant with sera of COVID-19 recovered cases and vaccinees of inactivated COVID-19 vaccine BBV152/Covaxin. J. Travel Med. 2021, 28, taab104. [CrossRef]

220. Sapkal, G.N.; Yadav, P.D.; Ella, R.; Deshpande, G.R.; Sahay, R.R.; Gupta, N.; Vadrevu, K.M.; Abraham, P.; Panda, S.; Bhargava, B. Inactivated COVID-19 vaccine BBV152/COVAXIN effectively neutralizes recently emerged B.1.1.7 variant of SARS-CoV-2. J. Travel Med. 2021, 28, taab051. [CrossRef] [PubMed]

221. Haas, E.J.; Angulo, F.J.; McLaughlin, J.M.; Anis, E.; Singer, S.R.; Khan, F.; Brooks, N.; Smaja, M.; Mircus, G.; Pan, K.; et al. Impact and effectiveness of mRNA BNT162b2 vaccine against SARS-CoV-2 infections and COVID-19 cases, hospitalisations, and deaths following a nationwide vaccination campaign in Israel: An observational study using national surveillance data. Lancet 2021, 397, 1819-1829. [CrossRef]

222. Chemaitelly, H.; Yassine, H.M.; Benslimane, F.M.; Al Khatib, H.A.; Tang, P.; Hasan, M.R.; Malek, J.A.; Coyle, P.; Ayoub, H.H.; Al Kanaani, Z.; et al. mRNA-1273 COVID-19 vaccine effectiveness against the B.1.1.7 and B.1.351 variants and severe COVID-19 disease in Qatar. Nat. Med. 2021, 27, 1614-1621. [CrossRef] [PubMed]

223. Tang, P.; Hasan, M.R.; Chemaitelly, H.; Yassine, H.M.; Benslimane, F.M.; Al Khatib, H.A.; AlMukdad, S.; Coyle, P.; Ayoub, H.H.; Al Kanaani, Z.; et al. BNT162b2 and mRNA-1273 COVID-19 vaccine effectiveness against the Delta (B.1.617.2) variant in Qatar. Nat. Med. 2021. [CrossRef]

224. Torres, I.; Albert, E.; Gimenez, E.; Alcaraz, M.J.; Botija, P.; Amat, P.; Remigia, M.J.; Beltrán, M.J.; Rodado, C.; Huntley, D.; et al. B and $\mathrm{T}$ cell immune responses elicited by the BNT162b2 (Pfizer BioNTech) COVID-19 vaccine in nursing home residents. medRxiv 2021. [CrossRef]

225. Yau, K.; Abe, K.T.; Naimark, D.; Oliver, M.J.; Perl, J.; Leis, J.A.; Bolotin, S.; Tran, V.; Mullin, S.I.; Shadowitz, E.; et al. Evaluation of the SARS-CoV-2 Antibody Response to the BNT162b2 Vaccine in Patients Undergoing Hemodialysis. JAMA Netw. Open 2021, 4, e2123622. [CrossRef]

226. Mark, C.; Gupta, S.; Punnett, A.; Upton, J.; Orkin, J.; Atkinson, A.; Clarke, L.; Heisey, A.; McGovern, C.; Alexander, S. Safety of administration of BNT162b2 mRNA (Pfizer-BioNTech) COVID-19 vaccine in youths and young adults with a history of acute lymphoblastic leukemia and allergy to PEG-asparaginase. Pediatric Blood Cancer 2021, 68, e29295. [CrossRef]

227. Male, V. Are COVID-19 vaccines safe in pregnancy? Nat. Rev. Immunol. 2021, 21, 200-201. [CrossRef]

228. Cosma, S.; Carosso, A.R.; Cusato, J.; Borella, F.; Carosso, M.; Bovetti, M.; Filippini, C.; D’Avolio, A.; Ghisetti, V.; Di Perri, G.; et al. Coronavirus disease 2019 and first-trimester spontaneous abortion: A case-control study of 225 pregnant patients. Am. J. Obstet. Gynecol. 2021, 224, 1-7. [CrossRef]

229. Lu-Culligan, A.; Iwasaki, A. The false rumors about vaccines that are scaring women. New York Times, 26 January 2021.

230. FDA. Pfizer-BioNTech COVID-19 Vaccine (BNT162, PF-07302048) Vaccines and Related Biological Products Advisory Committee Briefing Document. 2020. Available online: https://www.fda.gov/media/144246/download (accessed on 25 August 2021).

231. FDA. FDA Briefing Document Moderna COVID-19 Vaccine. 2020. Available online: https://www.fda.gov/media/144434 / download (accessed on 25 August 2021).

232. Medicines \& Healthcare Products Regulatory Agency. COVID-19 Vaccine AstraZeneca, Solution for Injection in Multidose Container COVID-19 Vaccine (ChAdOx1-S [Recombinant]). 2021. Available online: https:/ / assets.publishing.service.gov.uk/ government/uploads/system/uploads/attachment_data/file/963928/UKPAR_COVID_19_Vaccine_AstraZeneca_23.02.2021 .pdf (accessed on 27 August 2021).

233. Xiong, X.; Yuan, J.; Li, M.; Jiang, B.; Lu, Z.K. Age and gender disparities in adverse events following COVID-19 vaccination: Real-world evidence based on big data for risk management. Front. Med. 2021, 8, 700014. [CrossRef]

234. Dutta, S.; Kaur, R.J.; Bhardwaj, P.; Sharma, P.; Ambwani, S.; Islam, S.; Tandon, A.; Abhayanand, J.P.; Sukhija, S.; Venkatesh, S.S.; et al. Adverse events reported from the COVID-19 vaccines: A descriptive study based on the WHO database (VigiBase ${ }^{\circledR}$ ). J. Appl. Pharm. Sci. 2021, 11, 1-9.

235. Castelli, G.P.; Pognani, C.; Sozzi, C.; Franchini, M.; Vivona, L. Cerebral venous sinus thrombosis associated with thrombocytopenia post-vaccination for COVID-19. Crit. Care 2021, 25, 137. [CrossRef] 
236. Oldenburg, J.; Klamroth, R.; Langer, F.; Albisetti, M.; von Auer, C.; Ay, C.; Korte, W.; Scharf, R.E.; Pötzsch, B.; Greinacher, A. Diagnosis and management of vaccine-related thrombosis following AstraZeneca COVID-19 vaccination: Guidance statement from the GTH. Hämostaseologie 2021, 41, 184-189. [PubMed]

237. Oyston, P.; Robinson, K. The current challenges for vaccine development. J. Med. Microbiol. 2012, 61, 889-894. [CrossRef] [PubMed]

238. Smith, P.; Rodrigues, L.; Fine, P. Assessment of the protective efficacy of vaccines against common diseases using case-control and cohort studies. Int. J. Epidemiol. 1984, 13, 87-93. [CrossRef] [PubMed]

239. Halloran, M.E.; Longini, I.M., Jr.; Struchiner, C.J. Estimability and interpretation of vaccine efficacy using frailty mixing models. Am. J. Epidemiol. 1996, 144, 83-97. [CrossRef]

240. Adnan, N.; Khandker, S.S.; Haq, A.; Chaity, M.A.; Khalek, A.; Nazim, A.Q.; Kaitsuka, T.; Tomizawa, K.; Mie, M.; Kobatake, E.; et al. Detection of SARS-CoV-2 by antigen ELISA test is highly swayed by viral load and sample storage condition. Expert Rev. Anti Infect. Ther. 2021, 1-9, online ahead of print. [CrossRef] [PubMed]

241. Khandker, S.S.; Nik Hashim, N.H.H.; Deris, Z.Z.; Shueb, R.H.; Islam, M.A. Diagnostic Accuracy of Rapid Antigen Test Kits for Detecting SARS-CoV-2: A Systematic Review and Meta-Analysis of 17,171 Suspected COVID-19 Patients. J. Clin. Med. 2021, 10, 3493. [CrossRef] [PubMed]

242. Dorlass, E.G.; Monteiro, C.O.; Viana, A.O.; Soares, C.P.; Machado, R.; Thomazelli, L.M.; Araujo, D.B.; Leal, F.B.; Candido, E.D.; Telezynski, B.L.; et al. Lower cost alternatives for molecular diagnosis of COVID-19: Conventional RT-PCR and SYBR Green-based RT-qPCR. Braz. J. Microbiol. 2020, 51, 1117-1123. [CrossRef]

243. CDC. Immunization Services Division (ISD) National Center for Immunization and Respiratory Diseases (NCIRD). 2021. Available online: https:/ / www.cdc.gov/ncird/isd.html (accessed on 14 May 2021).

244. Jalkanen, P.; Kolehmainen, P.; Häkkinen, H.K.; Huttunen, M.; Tähtinen, P.A.; Lundberg, R.; Maljanen, S.; Reinholm, A.; Tauriainen, S.; Pakkanen, S.H.; et al. COVID-19 mRNA vaccine induced antibody responses against three SARS-CoV-2 variants. Nat. Commun. 2021, 12, 3991. [CrossRef] [PubMed]

245. Oishee, M.J.; Ali, T.; Jahan, N.; Khandker, S.S.; Haq, M.A.; Khondoker, M.U.; Sil, B.K.; Lugova, H.; Krishnapillai, A.; Abubakar, A.R.; et al. COVID-19 pandemic: Review of contemporary and forthcoming detection tools. Infect. Drug Resist. 2021, 14, 1049. [CrossRef] [PubMed]

246. Sil, B.K.; Jahan, N.; Haq, M.A.; Oishee, M.J.; Ali, T.; Khandker, S.S.; Kobatake, E.; Mie, M.; Khondoker, M.U.; Jamiruddin, M.R.; et al. Development and performance evaluation of a rapid in-house ELISA for retrospective sero-surveillance of SARS-CoV-2. PLoS ONE 2021, 16, e0246346. [CrossRef]

247. Jamiruddin, M.R.; Haq, M.A.; Tomizawa, K.; Kobatake, E.; Mie, M.; Ahmed, S.; Khandker, S.S.; Ali, T.; Jahan, N.; Oishee, M.J.; et al. Longitudinal Antibody Dynamics Against Structural Proteins of SARS-CoV-2 in Three COVID-19 Patients Shows Concurrent Development of IgA, IgM, and IgG. J. Inflamm. Res. 2021, 14, 2497. [CrossRef] [PubMed]

248. Wall, E.C.; Wu, M.; Harvey, R.; Kelly, G.; Warchal, S.; Sawyer, C.; Daniels, R.; Hobson, P.; Hatipoglu, E.; Ngai, Y.; et al. Neutralising antibody activity against SARS-CoV-2 VOCs B.1.617.2 and B.1.351 by BNT162b2 vaccination. Lancet 2021, 397, 2331-2333. [CrossRef]

249. Sil, B.K.; Jamiruddin, M.R.; Haq, M.A.; Khondoker, M.U.; Jahan, N.; Khandker, S.S.; Ali, T.; Oishee, M.J.; Kaitsuka, T.; Mie, M.; et al. AuNP Coupled Rapid Flow-Through Dot-Blot Immuno-Assay for Enhanced Detection of SARS-CoV-2 Specific Nucleocapsid and Receptor Binding Domain IgG. Int. J. Nanomed. 2021, 16, 4739. [CrossRef] [PubMed]

250. Haq, M.A.; Jamiruddin, M.; Khondoker, M.U.; Ahmed, M.F.; Khandker, S.S.; Ali, T.; Mostafi, M.; Sil, B.K.; Adnan, N.; Jamiruddin, M.R. Assessment of a rapid pan-antibody dot test for detection of antibodies against SARS-CoV-2. Bangladesh J. Med. Sci. 2021, 20, 131-139. [CrossRef]

251. Jamiruddin, M.R.; Haq, A.; Khondoker, M.U.; Ali, T.; Ahmed, F.; Khandker, S.S.; Jawad, I.; Hossain, R.; Ahmed, S.; Rahman, S.R.; et al. Antibody response to the first dose of AZD1222 vaccine in COVID-19 convalescent and uninfected individuals in Bangladesh. Expert Rev. Vaccines 2021, 1-10, online ahead of print. [CrossRef]

252. Fung, M.; Nambiar, A.; Pandey, S.; Aldrich, J.M.; Teraoka, J.; Freise, C.; Roberts, J.; Chandran, S.; Hays, S.R.; Bainbridge, E.; et al. Treatment of immunocompromised COVID-19 patients with convalescent plasma. Transpl. Infect. Dis. 2021, 23, e13477. [CrossRef]

253. Islam, M.A.; Khandker, S.S.; Kotyla, P.J.; Hassan, R. Immunomodulatory Effects of Diet and Nutrients in Systemic Lupus Erythematosus (SLE): A Systematic Review. Front. Immunol. 2020, 11, 1477. [CrossRef]

254. Islam, M.A.; Alam, S.S.; Kundu, S.; Prodhan, A.; Khandker, S.S.; Reshetnyak, T.; Kotyla, P.J.; Hassan, R.; Hossan, T. Prevalence of antiphospholipid antibodies in Behçet's disease: A systematic review and meta-analysis. PLoS ONE 2020, 15, e0227836. [CrossRef]

255. Vallée, A.; Vasse, M.; Mazaux, L.; Bonan, B.; Amiel, C.; Zia-Chahabi, S.; Chan-Hew-Wai, A.; Farfour, E.; Camps, E.; Touche, P.; et al. An Immunogenicity Report for the Comparison between Heterologous and Homologous Prime-Boost Schedules with ChAdOx1-S and BNT162b2 Vaccines. J. Clin. Med. 2021, 10, 3817. [CrossRef] [PubMed]

256. Liu, X.; Shaw, R.H.; Stuart, A.S.; Greenland, M.; Aley, P.K.; Andrews, N.J.; Cameron, J.C.; Charlton, S.; Clutterbuck, E.A.; Collins, A.M.; et al. Safety and immunogenicity of heterologous versus homologous prime-boost schedules with an adenoviral vectored and mRNA COVID-19 vaccine (Com-COV): A single-blind, randomised, non-inferiority trial. Lancet 2021, 398, 856-869. [CrossRef] 
257. Barros-Martins, J.; Hammerschmidt, S.I.; Cossmann, A.; Odak, I.; Stankov, M.V.; Morillas Ramos, G.; Dopfer-Jablonka, A.; Heidemann, A.; Ritter, C.; Friedrichsen, M.; et al. Immune responses against SARS-CoV-2 variants after heterologous and homologous ChAdOx1 nCoV-19/BNT162b2 vaccination. Nat. Med. 2021, 27, 1525-1529. [CrossRef]

258. Ostadgavahi, A.T.; Booth, R.; Sisson, G.; McMullen, N.; Warhuus, M.; Robertson, P.; Miller, M.; Allen, W.C.; El Sherif, M.; Brownlie, R.; et al. Heterologous immunization with Covishield and Pfizer vaccines against SARS-CoV-2 elicits a robust humoral immune response. J. Infect. Dev. Ctries. 2021, 15, 653-656. [CrossRef] [PubMed]

259. Wanlapakorn, N.; Suntronwong, N.; Phowatthanasathian, H.; Yorsang, R.; Thongmee, T.; Vichaiwattana, P.; Auphimai, C.; Wongsrisang, L.; Klinfueng, S.; Sudhinaraset, N.; et al. Immunogenicity of heterologous prime/booster-inactivated and adenoviral-vectored COVID-19 vaccine: Real-world data. Res. Sq. 2021. [CrossRef]

260. Lin, A.; Liu, J.; Ma, X.; Zhao, F.; Yu, B.; He, J.; Shen, M.; Huang, L.; Tang, H.; Jiang, E.; et al. Heterologous vaccination strategy for containing COVID-19 pandemic. medRxiv 2021. [CrossRef]

261. Hwang, S.E.; Kim, W.H.; Heo, J. Socio-demographic, psychological, and experiential predictors of COVID-19 vaccine hesitancy in South Korea, October-December 2020. Hum Vaccin Immunother 2021, 1-8. [CrossRef]

262. Alam, A.M.; Majumder, M.A.A.; Haque, M.; Ashraf, F.; Khondoker, M.U.; Mashreky, S.R.; Wahab, A.; Siddiqui, T.H.; Uddin, A.; Joarder, T.; et al. Disproportionate COVID-19 vaccine acceptance rate among healthcare professionals on the eve of nationwide vaccine distribution in Bangladesh. Expert Rev. Vaccines 2021, 20, 1167-1175. [CrossRef]

263. Nonaka, C.K.; Franco, M.M.; Gräf, T.; de Lorenzo Barcia, C.A.; de Ávila Mendonça, R.N.; de Sousa, K.A.F.; Neiva, L.M.C.; Fosenca, V.; Mendes, A.V.A.; de Aguiar, R.S.; et al. Genomic Evidence of SARS-CoV-2 Reinfection Involving E484K Spike Mutation, Brazil. Emerg. Infect. Dis. 2021, 27, 1522-1524. [CrossRef]

264. Adnan, N.; Khondoker, M.U.; Rahman, M.S.; Ahmed, M.F.; Sharmin, S.; Sharif, N.; Azmuda, N.; Akter, S.; Nahar, S.; Mou, T.J. Coding-Complete Genome Sequences and Mutation Profiles of Nine SARS-CoV-2 Strains Detected from COVID-19 Patients in Bangladesh. Microbiol. Resour. Announc. 2021, 10, e00124-21. [CrossRef]

265. Hirotsu, Y.; Omata, M. Discovery of a SARS-CoV-2 variant 1 from the P.1 lineage harboring K417T/E484K/N501Y mutations in Kofu, Japan. J. Infect. 2021, 82, 276-316. [CrossRef] [PubMed]

266. Tang, J.W.; Toovey, O.T.; Harvey, K.N.; Hui, D.D.S. Introduction of the South African SARS-CoV-2 variant 501 Y.V2 into the UK. J. Infect. 2021, 82, 8-10. [CrossRef] [PubMed]

267. Matin, M.A.; Nahid, A.A.; Sarkar, B.; Ullah, M.A.; Araf, Y.; Adnan, N.; Islam, R.; Rahman, M.S. Genome Sequences of Two Novel Coronavirus (SARS-CoV-2) Isolates from Dhaka, Bangladesh. Microbiol. Resour. Announc. 2021, 10, e00511-21. [CrossRef]

268. Sahoo, J.P.; Mishra, A.P.; Samal, K.C. Triple Mutant Bengal Strain (B.1.618) of Coronavirus and the Worst COVID Outbreak in India. Biot. Res. Today 2021, 3, 261-265.

269. Naveca, F.; da Costa, C.; Nascimento, V.; Souza, V.; Corado, A.; Nascimento, F.; Costa, A.; Duarte, D.; Silva, G.; Mejía, M.; et al. SARS-CoV-2 reinfection by the new Variant of Concern (VOC) P.1 in Amazonas, Brazil. Virological 2021. Available online: https:/ /virologicalorg/t/sars-cov-2-reinfection-by-thenew-variant-of-concern-voc-p-1-in-amazonas-brazil/596 (accessed on 25 June 2021).

270. Crasto, A. BBIBP-CorV, Sinopharm COVID-19 Vaccine. New Drug Approvals. Available online: https:/ / newdrugapprovals.org/ 2021/03/23/bbibp-corv-sinopharm-covid-19-vaccine/ (accessed on 12 April 2021).

271. Wee, S.-L.; Qin, A. China approves COVID-19 vaccine as it moves to inoculate millions. New York Times, 30 December 2020. 